Universidad Nacional de La Plata

Facultad de Periodismo y Comunicación Social

Maestría en Planificación y Gestión de Procesos Comunicacionales

\title{
Diagnóstico de los procesos comunicacionales desarrollados en la Mesa de Gestión Ambiental de Cruz Alta
}

Directora: Lic. (MSc.) Marina Buschiazzo

Co-directora: Ing. Agr. (MSc.) Cristina Biaggi

Tesista: Lic. María Nilce Felipe 
A mi hija Martina y a mi compañero de vida Álvaro por acompañarme y ceder parte de su tiempo en este largo proceso.

A mi familia, especialmente a mis padres, $y$ amigas por escucharme y apoyarme en los diferentes momentos.

A mis amigos del trabajo Cristina, Mariano y Alejandro por la oportunidad, colaboración y paciencia en esta construcción.

A mis compañeros de la Mesa de Gestión Ambiental de Cruz Alta por poner sus voces, pensamientos y propuestas en esta tesis.

A mi directora Marina por guiarme y aportar en cada etapa del proceso transcurrido. 


\section{ÍNDICE}

INTRODUCCIÓN

Presentación del problema. $\quad 6$

Expectativas de cambio. $\quad 8$

CAPÍTULO I: PROVINCIA DE TUCUMÁN 10

Presentación de Tucumán. 11

Descripción del Departamento Cruz Alta. 16

La agroindustria de la caña de azúcar.

CAPÍTULO II: PROBLEMÁTICA DE LA QUEMA EN TUCUMÁN 24

Historicidad de la quema como método auxiliar de la cosecha. 24

Consecuencias del uso del fuego. 28

Legislación vigente. 33

Alternativas tecnológicas para la erradicación de la quema. 38

Propuestas de reemplazo para la quema de caña. 39

Propuestas de valorización de la maloja. $\quad 40$

CAPÍTULO III: MESA DE GESTIÓN AMBIENTAL DE CRUZ ALTA 44

EI INTA en el territorio. $\quad 45$

Conformación de la Mesa de Gestión Ambiental de Cruz Alta. 52

Caracterización de los actores de la organización. 56

Dirección Provincial de Defensa Civil. 58

$\begin{array}{ll}\text { Sistema Provincial de Salud. } & 60\end{array}$

Empresa Agrícola Juan José Budeguer. 62

Empresa Los Cevilares S. A. $\quad 64$

Empresa PAP. $\quad 65$

$\begin{array}{ll}\text { Cañeros Unidos del Este. } & 67\end{array}$

Dirección Provincial de Fiscalización Ambiental. 68

Asociación de Bomberos Voluntarios de Las Talitas. 70

Secretaría de Estado de Medio Ambiente. 72

$\begin{array}{ll}\text { Estación Experimental Agroindustrial Obispo Colombres. } & 74\end{array}$

Fundación ProYungas y Defensoría del Pueblo de Tucumán. 75

$\begin{array}{ll}\text { Transener S. A. } & 77\end{array}$

Dirección Provincial de Flora, Fauna Silvestre y Suelos. 79 
Cooperativa La Merced.

Otros sujetos, otros relatos.

CAPÍTULO IV: PROCESOS COMUNICACIONALES DESARROLLADOS

EN LA ORGANIZACIÓN 85

Etapa 1. Programa de erradicación de la quema. 87

Plan destinado a los productores cañeros. 96

Plan destinado a la sociedad civil. 99

Etapa 2. Productos comunicacionales elaborados. 108

Afiches y comunicados de prensa. 110

Video y Folleto "Prender fuego no es un juego". 118

Spots y Volante "Entre todos podemos cuidar nuestra provincia". 121

CAPÍTULO V: CONSIDERACIONES FINALES Y PROPUESTAS DE

CAMBIO

126

Construcción de las propuestas de cambio. 132

Etapa 1. Debilidades y fortalezas. 133

Etapa 2. Líneas de acción propuestas. 139

$\begin{array}{ll}\text { BIBLIOGRAFÍA } & 154\end{array}$

ANEXOS I-XVI 


\section{RESUMEN DE TESIS}

Esta investigación-acción se constituyó como un diagnóstico comunicacional sobre los procesos desarrollados en la Mesa de Gestión Ambiental de Cruz Alta.

La Mesa es una organización social interinstitucional y multidisciplinaria, conformada en el año 2010 con el objetivo de lograr la erradicación gradual de la quema de caña de azúcar en el departamento Cruz Alta de la provincia de Tucumán, Argentina. Esta problemática incide desfavorablemente en lo ambiental, la salud de las personas, ocasionando riesgos de cortes en el suministro eléctrico y daños en las infraestructuras.

Así fue que entre el 2010 y 2012, la Organización realizó un diagnóstico sobre la problemática y diseñó un programa, dentro del cual se elaboraron productos comunicacionales, con dos problemas: la ausencia de una planificación de las actividades y el predominio del enfoque operativo-instrumental de la comunicación en algunas de sus estrategias.

Ante esta realidad comunicacional, nos propusimos los siguientes objetivos:

1- Describir, analizar y evaluar los procesos comunicacionales -procesos de diálogo y productos- desarrollados en y por la organización, a través de las etapas de diagnóstico, planificación y gestión.

2- Proponer líneas de acción comunicacionales a partir de los problemas construidos a lo largo de la investigación.

Para abordar estos objetivos, guiamos nuestra mirada comunicacional desde una perspectiva teórica que entiende a la comunicación como relación social y cultural con sujetos que interactúan en prácticas socio-culturales. Lo comunicacional, entonces, trasciende los medios y las técnicas y se sitúa en la complejidad de las relaciones entre actores, en el espacio de las prácticas sociales y las organizaciones donde se generan las producciones sociales de sentidos.

La metodología para desarrollar este trabajo posgradual fue el diagnóstico participativo utilizando, además, las herramientas de recopilación de materiales, observación participante, entrevistas semi-estructuradas, análisis de discurso, análisis de marcas de racionalidad y talleres participativos. Mediante estas herramientas, trabajamos con los integrantes de la Mesa para identificar las debilidades y fortalezas de la organización, definir los nudos críticos sobre los que se pudieran planificar procesos de cambio y, finalmente, proponer líneas de acción que permitan la transformación de su realidad.

A partir de las propuestas de los actores, sustentadas en las condiciones de viabilidad y factibilidad organizacionales, reconocemos que existen posibilidades dentro de la organización de rediseñar sus estrategias desde una mirada de la comunicación concebida como instancia de puesta en común, donde la participación y la construcción conjunta son elementos indispensables. También desde una concepción de la planificación y gestión como proceso dinámico, complejo e integral que incluye las fases de diagnóstico, planificación, diseño de estrategias, ejecución y evaluación en continua evolución y complejidad. 


\section{THESIS SUMMARY}

This research-action has been conducted as a communication diagnosis on those processes developed by the Environmental Management Board in Cruz Alta.

The Board is an inter-institutional and multidisciplinary social organization established in 2010 to gradually eradicate sugar cane burning in Cruz Alta, province of Tucumán, Argentina. This problem results an unfavorable factor for the environment and population health, provoking cuts of electricity service and damages in infrastructure.

Thus, between 2010 and 2012, the Organization has carried out a diagnosis on this issue and has outlined a program, containing communication products, posing two problems: the absence of an action plan and the preeminence of the operation-instrumental approach of communication in some of its strategies.

Facing this communicational reality, we have proposed the following objectives:

1- To describe, analyze and evaluate communication processes -dialogue and product processes- developed in and by the Organization throughout the stages of diagnosis, planning and management.

2- To propose action lines in communication, taking as a starting point any issues settled along the investigation.

In order to deal with the aforementioned objectives, we directed our communicational analysis from a theoretical perspective considering communication as a social and cultural relation with subjects interacting in socio-cultural practices. Therefore, communication exceeds the means and the methods and lies in the complexity of relations among actors, in the context of social practices and those organizations where social production of meanings are generated.

The methodology applied to develop this postgraduate work was the participation diagnosis using, as well, tools to collect materials, participant observation, semi-structured interviews, discourse analysis, analysis of rationality marks and actively participated workshops. By means of these tools, we worked with the members of the Board to identify weaknesses and strengths of the Organization, to define the critical issues to plan change processes thereon and finally, to propose action lines enabling the transformation of this reality.

Departing from actors' proposals supported by viability conditions and organizational feasibility, we admit that, within the organization, it is possible to redesign its strategies based on communication as a result of sharing ideas, where joint participation and construction are essential elements. Also, considering planning and management as a dynamic, complex and integral process, and including phases of diagnosis, planning, design of strategies, execution and assessment in permanent evolution and complexity. 


\section{RESUMO DE TESE}

A presente pesquisa-ação foi formulada como um diagnóstico comunicacional sobre os processos desenvolvidos pela Mesa de Gestão Ambiental de Cruz Alta, na província de Tucumán, Argentina.

A Mesa é uma organização social interinstitucional e multidisciplinária, formada no ano 2010 com o objetivo de lograr a erradicação gradual da queimada de cana de açúcar na área de Cruz Alta. Esta problemática incorre de maneira desfavorável no meio ambiente e na saúde das pessoas, causando riscos de queda da energia elétrica e danos nas infraestruturas.

Foi assim como, entre os anos 2010 e 2012, a organização realizou um diagnóstico sobre a problemática e desenhou um programa, dentro do qual se elaboraram produtos comunicacionais, com dois problemas: a ausência de planificação das atividades e o predomínio do enfoque operativo-instrumental da comunicação em relação com algumas das suas estratégias.

Perante esta realidade comunicacional, foram propostos os seguintes objetivos:

1- Descrever, analisar e avaliar os processos comunicacionais -processos de diálogo e produtos- desenvolvidos na organização e pela organização, através das etapas de diagnóstico, planificação e gestão.

2- Propor linhas de ação comunicacionais a partir dos problemas construídos durante a pesquisa.

Estes objetivos foram abordados com uma visão comunicacional, desde uma perspectiva teórica que compreende a comunicação como uma relação social e cultural de sujeitos que inter-atuam nas práticas sócio-culturais. O comunicacional, então, vai além dos meios e das técnicas, se colocando na complexidade das relações entre agentes, no espaço das práticas sociais e das organizações onde as produções sociais dos sentidos são geradas.

A metodologia desenvolvida neste trabalho foi o diagnóstico participativo, e se utilizando também, colheita de materiais, observação participante, entrevistas semiestruturadas, análise do discurso, análise de marcas de racionalização e oficinas participativas, como ferramentas de pesquisa. Através delas, os membros da Mesa trabalharam conjuntamente, visando: identificar as debilidades e fortalezas da organização, definir os pontos críticos sobre os que algumas mudanças poderiam ser planejadas e, finalmente, propor linhas de ação para a transformação de sua realidade.

A partir das propostas dos agentes, sustentadas por condições de viabilidade e factibilidade da organização, observou-se a existência de possibilidades dentro dela para redesenhar suas estratégias, não somente considerando a comunicação como uma ação de troca de conceitos comuns, na qual a participação e a construção conjunta são elementos indispensáveis, mas também desde a concepção de o planejamento e a gestão serem processos dinâmicos, complexos e integrais, que incluem as fases de diagnóstico, planificação, desenho de estratégias, execução e avaliação, em uma contínua evolução e complexidade. 
En esta tesis nos proponemos llevar adelante un trabajo de investigaciónacción desde la perspectiva PLANGESCO para abordar los procesos comunicacionales desarrollados en la Mesa de Gestión Ambiental de Cruz Alta". En palabras de Washington Uranga (2001: 59) consideramos a esta "investigación como espacio de creación y de producción de conocimientos a partir de la síntesis de los marcos teóricos transdisciplinares y de las experiencias sociales atravesadas por los procesos culturales y comunicacionales".

La Mesa es una organización social interinstitucional y multidisciplinaria, conformada en el año 2010 con el objetivo de lograr la erradicación gradual de la quema de caña de azúcar en el departamento Cruz Alta de la provincia de Tucumán, Argentina.

La misma está integrada por diferentes actores relacionados con la temática, que pertenecen a las siguientes instituciones y organizaciones: INTA; Secretaría de Medio Ambiente, Dirección de Flora y Fauna, Dirección de Defensa Civil y Dirección de Fiscalización Ambiental del Gobierno de la Provincia de Tucumán; Sistema Provincial de Salud (SIPROSA); Asociación Bomberos Voluntarios de Las Talitas; organización gremial Cañeros Unidos del Este; Cooperativa La Merced; empresas Juan José Budeguer, Los Cevilares y PAP Productores; pequeños y medianos productores independientes; Estación Experimental Agroindustrial Obispo Colombres; Fundación PROYUNGAS y Empresa Transener S.A.

Para lograr su propósito, entre el 2010 y 2012, el colectivo de actores de La Mesa desarrolló un diagnóstico sobre la realidad de la quema de caña de azúcar en Tucumán y diseñó un programa para erradicarla, dentro del cual se elaboraron productos comunicacionales.

Nuestro objetivo, entonces, es realizar un diagnóstico comunicacional para describir y analizar desde una mirada histórica esa realidad (las prácticas y relaciones) construida por los actores, dando lugar a la propuesta de líneas de acción que generen los cambios deseados. Desde la perspectiva PLANGESCO, entendemos a este diagnóstico como un proceso dinámico de construcción de conocimientos y propuestas para comenzar a transformar la realidad de la organización y sus prácticas en el territorio.

\footnotetext{
${ }^{1}$ De ahora en adelante referida como La Mesa.
} 
Este desafío implica identificar las características propias de cada situación y reconocer la trama compleja de las relaciones y a los actores que se constituyen en la misma. Como propone Claudia Villamayor (2002: 47), este camino de construcción de la realidad comunicacional de la Mesa involucra "la descripción, el análisis, el discernimiento y la valoración de las situaciones de comunicación objeto de estudio, para reconocer allí las significaciones y los productos de comunicación y cómo cada uno de los actores se constituye en la trama siempre compleja de las relaciones y las prácticas sociales. Todo con el objetivo final de comprender los procesos organizacionales y, de esta manera, generar condiciones para desatar procesos de cambio planificado".

Mi vínculo con la Mesa se dio desde el momento de su creación, cuando me incorporé como una de las representantes del INTA. A partir de allí jugué el doble rol de integrante/actor e investigadora. En el primer caso formé parte de la construcción y ejecución del programa de erradicación progresiva de la Mesa. Desde entonces se inició la producción de conocimientos en este diagnóstico donde pude reconocer los procesos comunicacionales desarrollados e identificar sus problemas/debilidades y fortalezas para fomentar las posibilidades de cambio.

Esto permitió al área de comunicaciones del INTA Famaillá, en la cual trabajo desde el año 2007, iniciar su primera experiencia ligada a una mirada relacional de la comunicación, a partir del trabajo en terreno junto a los actores sociales para abordar una problemática como la quema de caña. Hasta ese momento, funcionaba exclusivamente como un servicio de apoyo y asistencia al resto de los grupos de trabajo de la Institución desde un enfoque operativo instrumental basado en la trasmisión de información tanto interna como externamente.

Esta propuesta epistemológica de intervención social y política, que implica una mirada propia desde el campo de la comunicación para diagnosticar y crear las condiciones para la planificación y gestión de un proceso de transformación, tiene como objetivos:

1- Describir, analizar y evaluar los procesos comunicacionales -procesos de diálogo y productos- desarrollados en y por la organización, a través de las etapas de diagnóstico, planificación y gestión. 
2- Proponer líneas de acción comunicacionales a partir de los problemas construidos a lo largo de la investigación.

Para iniciar este recorrido analítico-reflexivo partiremos de la descripción de las condiciones políticas, productivas-económicas y sociales existentes en Tucumán y en el departamento Cruz Alta, permitiéndonos situar contextualmente la organización a diagnosticar en la tesis.

Luego, considerando el propósito de la Mesa, continuaremos el análisis sobre las condiciones en las que se desarrolla la agroindustria cañera en la provincia y la utilización de la quema como herramienta de producción en el cultivo. Los ejes serán: su historicidad, consecuencias de la práctica, legislación que la prohíbe y alternativas tecnológicas desarrolladas para su erradicación.

El siguiente paso será la realización de un pre-diagnóstico sobre La Mesa para conocer las condiciones en las que se gestó y los sujetos sociales que la integran, indagando en las miradas e intereses de cada uno.

A partir de allí, construiremos la realidad comunicacional de la Mesa mediante la descripción, análisis, discernimiento y valoración de las situaciones de comunicación de la organización en dos etapas de análisis. La primera será el proceso de elaboración y ejecución de la "Propuesta de Programa de Erradicación Progresiva de la Quema de Caña de Azúcar en el Departamento"; la segunda, la construcción y uso de los productos comunicacionales elaborados.

Finalmente, los problemas construidos a lo largo de la investigación nos permitirán trabajar en la definición y propuesta de líneas de acción comunicacionales superadoras que permitan rediseñar de manera planificada las estrategias de la organización en el territorio.

Es importante considerar que cuando intervenimos en una práctica social para crear procesos de cambio entran en juego nuestro propio legado subjetivo, el marco teórico-metodológico que utilizamos y las matrices socio-culturales y el desempeño de los actores sociales durante y en el proceso de investigación. Como afirma Rosana Guber (2001: 44), "para que el investigador pueda describir la vida social que estudia incorporando la perspectiva de sus miembros, es necesario someter a continuo análisis las tres reflexividades que están permanentemente en juego en el trabajo de campo: la reflexividad del investigador en tanto que miembro de una sociedad o cultura; la reflexividad del investigador en tanto que investigador, 
con su perspectiva teórica, sus interlocutores académicos, sus hábitus disciplinarios y su epistemocentrismo; y las reflexividades de la población en estudio".

Por esto, reconocemos como necesario explicar desde qué perspectiva teórico-metodológica abordaremos el análisis de los procesos comunicacionales desarrollados en la Mesa de Gestión Ambiental de Cruz Alta.

En este sentido, la mirada comunicacional de nuestra tesis se guiará desde una perspectiva teórica que entiende a la comunicación como relación social y cultural con sujetos que interactúan en prácticas socio-culturales donde intervenimos para diseñar procesos de cambio. Lo comunicacional, entonces, trasciende los medios y las técnicas y se sitúa en la complejidad de las relaciones entre actores y sujetos, en el espacio de las prácticas sociales y las organizaciones donde se generan las producciones sociales de sentidos.

Sandra Massoni (2007: 35) explica que "la comunicación es el momento relacionante de la diversidad sociocultural. Apostar a organizar una intervención en la dinámica socio-cultural es recuperar a la comunicación como un proceso abierto y permanente de sentido".

Nos referimos a comprender "la comunicación como una perspectiva de abordaje factible de ser aplicada a cualquier práctica social, una forma de posicionarse, en primer lugar, para el análisis, pero también de construir un modo de intervención que tiene como fin último el cambio. Este modo de intervención, encaminado hacia un horizonte, supone planificación de la acción y, al mismo tiempo, políticas y estrategias para llevarla a cabo, es decir, gestión" (Uranga, 2001: 32).

Siguiendo esta propuesta teórica, consideramos a las etapas de diagnóstico, planificación y gestión de estrategias para la acción como tres momentos de un mismo proceso de conocimiento y de intervención y, por lo tanto, indisociables. Así, el ideal de todo proyecto es contar con un diagnóstico, la planificación, el diseño de estrategias, la ejecución y la evaluación como fases necesarias para evitar la improvisación en la conducción hacia el futuro deseado.

La metodología para llevar adelante este trabajo de investigación posgradual será el diagnóstico dinámico participativo para involucrar a los actores de la organización en la identificación de sus problemas y la construcción de las propuestas para resolverlos. 
Entendemos al diagnóstico como "una lectura esencial de determinada realidad social, una lectura de sus conexiones esenciales, desde una perspectiva histórica" (Prieto Castillo, 1990: 41). Decimos que es dinámico porque es algo siempre inacabado, que atraviesa todo el proceso de planificación y a medida que avanza logra un progreso en la reflexión con la incorporación de nuevos elementos que enriquecen la mirada. $Y$ es participativo porque se basa en el reconocimiento de los saberes presentes en los actores protagonistas de cada espacio social y la participación de los grupos e instituciones relacionadas con el problema. En este sentido, consideramos que todos los seres humanos somos sujetos de conocimiento porque conocemos verdaderamente cuando producimos la acción. Como explica Juan Samaja (2006: 50), "lo que yo hago, eso es lo verdadero. Y eso lo puedo conocer con verdad, con evidencia plena sólo porque lo he hecho".

Las herramientas metodológicas que utilizaremos para construir las etapas de análisis en los diferentes capítulos propuestos serán la recopilación de materiales, la observación participante, entrevistas semi-estructuradas, análisis de discurso, registro de marcas de racionalidad y talleres participativos.

Es importante considerar que en los relatos los sujetos manifiestan la construcción que hacen de su realidad. Los discursos y las acciones de los actores dan cuenta de las matrices socio-culturales que los atraviesan, a través de las cuales construyen y son construidos a la vez por ese mundo de significaciones. Entendemos por matriz sociocultural el "esquema básico que describe los rasgos principales de la lógica de funcionamiento de un grupo social. Una matriz sociocultural programa en cada grupo su sistema de percepción-acción. Incluye no sólo las condiciones, sino la percepción que cada grupo tiene de ellas (lo simbólico y lo material imbricados)" (Massoni, 2007: 31).

Por esto, Jesús Martín Barbero (1987: 35) señala que "es imposible seguir estudiando el lenguaje como puro medio de comunicación y es necesario investigarlo como trabajo clave de la producción significante [...] el lenguaje no habita otro mundo que el nuestro y es de ese mundo impuro y conflictivo que están hechas las palabras". 


\section{Presentación del problema}

Desde una concepción que entiende a la comunicación como producción social de sentidos, reconocemos que el principal problema que tuvo la Mesa de Gestión Ambiental de Cruz Alta para llevar adelante su programa de erradicación progresiva de la quema fue, por un lado, la ausencia de una planificación de las actividades y, por otro, el predominio del enfoque operativo-instrumental en algunas de sus estrategias comunicacionales.

La falta de una programación en general dentro del programa que defina interlocutores, modalidades de ejecución, actividades o tareas para generar los resultados esperados, recursos (económicos, humanos y materiales) necesarios y un sistema de evaluación generó diversas dificultades. Entre ellas, la falta de cumplimiento de las metas previstas y la ausencia de una continuidad en la selección, producción, contenidos y ejecución de los productos mediáticos elaborados.

En este sentido, consideramos fundamental para cualquier proyecto contar con una planificación que permita dar sistematicidad a las acciones para alcanzar el futuro deseado y evitar la improvisación. Claudia Villamayor (2002: 56) entiende que "planificar es elegir hacia donde queremos caminar, establecer las metas hacia donde queremos dirigirnos como organización, fijando no sólo los propósitos, sino también los mecanismos y procedimientos para alcanzarlos. Planificar implica reflexionar críticamente sobre el lugar donde estamos, elegir el punto de destino, construir los pasos y las etapas para llegar hasta el mismo".

Relacionado a esto, la mirada instrumental de la comunicación de la Mesa se registró en un trabajo enfocado principalmente al diseño de productos para persuadir a través de los medios de comunicación. En este sentido, se crearon y difundieron afiches, folletos, spots y comunicados de prensa con el objetivo de lograr "un cambio de actitud"2 en la población. Además, no se contó con el diagnóstico y planificación de una estrategia de medios que permita colocar esos materiales con su propuesta sobre la problemática de la quema en la agenda pública.

\footnotetext{
${ }^{2}$ Se utiliza la cursiva para hacer referencia a la cita textual de la Propuesta de Programa de Erradicación Progresiva de la Quema de Caña de Azúcar en el Departamento construida por la Mesa.
} 
Esta concepción de la comunicación como herramienta para crear mensajes para persuadir a los destinatarios se basa en un concepto predominante en los años 60 , donde se consideraba a los receptores de los medios como meros destinatarios, pasivos, desconociendo la subjetividad, el tejido cultural en el que se desarrollaba la recepción.

Ante los límites de este enfoque, Florencia Saintout (1998: 157) propone:

El pasaje de una teoría comunicacional positivista anclada en la fragmentación polar de los emisores-receptores, hacia una teoría de la producción social de las significaciones; a una etnología de la cultura, que trabaja las complejas relaciones entre los procesos de recepción de bienes simbólicos y la producción, integrándolos a las dimensiones políticas y sociales. Historizando prácticas y sentidos. Problematizando lo cotidiano en su relación con el hacer y hacerse en realidades posibles de modificar desde la libertad condicional que suponen las transversalidades de los lugares/no lugares.

Por otra parte, la estrategia creada por la Mesa para involucrar a los productores en la transformación se basó en la difusión de un documento, sin generar espacios de reflexión y construcción en común de las propuestas de cambio. Los límites de la acción fueron tal vez desconocer las condiciones sociales y culturales en las que la gente toma decisiones para poder involucrar la participación de todos los agentes implicados en el cambio.

Como explican los autores de la Antología de Comunicación para el Cambio Social, "los expertos ajenos a las comunidades no deberían seguir imponiendo fórmulas gastadas para encarar las necesidades sociales urgentes. La gente puede encontrar respuestas si tiene la oportunidad de reunirse y debatir sus problemas, de buscar soluciones colectivamente y de proyectar modos de enfrentar sus problemas" (Gumucio Dragón y Tufte, 2008: 17).

Sin embargo, la Mesa tuvo un acercamiento al trabajo de la comunicación como proceso relacional al reunir y poner a dialogar a los diferentes actores vinculados a la quema de caña de azúcar en el territorio para pensar la transformación, dando lugar a la construcción de un diagnóstico de forma participativa y generando nuevos conocimientos, en especial desde la experiencia 
de cada actor. También, diseñó una metodología participativa para involucrar a los niños en la construcción de los conocimientos sobre la problemática, proponiéndolos además como educadores en su comunidad.

\section{Expectativas de cambio}

En cuanto a las expectativas de cambio que tenemos con el desarrollo de este diagnóstico comunicacional, lo primero es poder reconocer y analizar las prácticas y relaciones que se tejieron entre los actores de La Mesa durante el proceso de desarrollo del programa de erradicación progresiva de la quema. Esto implica el abordaje desde los espacios de construcción y toma de decisiones en la Organización, los roles de cada sujeto y los materiales y productos mediáticos elaborados. Este registro nos permitirá construir nuevos procesos de transformación ajustados al trabajo desarrollado durante los tres años de los actores de la Mesa sobre la problemática convocante.

Además existe una fuerte convicción de crear expectativas entre los actores cuando compartamos este trabajo de investigación, donde la devolución sea más bien un motivo de auspiciar espacios de participación, construcción y toma de decisiones para que puedan reconocer las limitaciones y fortalezas de la experiencia organizacional realizada y definir qué prácticas desean construir desde entonces para rediseñar sus estrategias en el territorio.

Por otro lado, los alcances esperados a nivel personal y profesional son la posibilidad de adquirir conocimientos y herramientas que me permitan trabajar en los diferentes territorios y organizaciones con un enfoque específicamente comunicacional. Desde ya, esto desafiaría el enfoque operativo-instrumental predominante en el área de comunicaciones del INTA Famaillá, apuntando a incorporar una nueva perspectiva que entiende al comunicador como "un científico social que posee saberes, capacidades y destrezas que le permiten facilitar el diálogo público entre actores diversos en el espacio público. Y el planificador de procesos comunicacionales entendido como aquel comunicador que trabaja en la articulación productiva de saberes y capacidades de estos distintos actores en función de la construcción de consensos en escenarios de transformación" (Uranga, 2008: 6). 
Por último, con esta tesis esperamos realizar un aporte para perfeccionar, sistematizar, enriquecer y dinamizar propuestas de planificación y gestión en el campo de la comunicación de acuerdo al sentido de la propuesta de formación superior de PLANGESCO.

De este modo, con este trabajo científico y epistemológico esperamos dar cuenta de que:

- La comunicación trasciende los medios y las técnicas y se sitúa en el vínculo entre los actores sociales, en el espacio de las prácticas sociales y las organizaciones, donde se genera la producción social de sentidos. Es decir, en la cultura.

- Toda práctica social puede ser abordada analíticamente desde la comunicación para construir procesos de transformación.

- Dicha construcción, desde el aporte de la mirada comunicacional, significa diagnosticar una realidad para definir líneas de acción, lo cual implica también planificación y gestión para el desarrollo de las estrategias en función del futuro deseado.

- En las bases de esta construcción se encuentra el registro teórico de saberes interrelacionados con los actores y sus experiencias. Por esto, se trata de un proceso dialógico de construcción de conocimientos entre todos los actores participantes del proceso social (involucrando al investigador).

- El rol del comunicador-investigador es, por un lado el de un gestor de procesos comunicacionales, es decir, un articulador de saberes y prácticas, poniéndolas en relación, ya que todos los actores están en capacidad de planificar; y por el otro, el de un procesador de estas construcciones en un trabajo de investigación como esta tesis de posgrado.

En esta búsqueda emprendemos esta tesis posgradual donde "no se busca sólo enriquecer la ciencia de la comunicación, sino también, y de manera fundamental, enriquecer el conocimiento sobre diferentes instituciones y sobre los posibles espacios de trabajo en planificación y gestión de la comunicación" (Uranga 2001: 42). 


\section{CAPÍTULO I: PROVINCIA DE TUCUMÁN}

Para situar contextualmente la construcción del diagnóstico comunicacional de esta tesis y comprender el proceso de desenvolvimiento de la Mesa de Gestión Ambiental de Cruz Alta en relación a la problemática de la quema de caña en Tucumán, es necesario realizar un registro de las condiciones políticas, productivaseconómicas y sociales existentes en la Provincia y, específicamente, en el departamento Cruz Alta. Es decir, conocer las particularidades del territorio, entendido como el espacio donde se realiza la construcción social de sentidos, en el cual se sitúa la práctica que nos proponemos investigar.

El abordaje de las prácticas sociales desde la comunicación implica, necesariamente, inscribirla en la complejidad del campo de la cultura, dado que en el escenario de la vida social, los sujetos de esas prácticas se encuentran atravesados por las dimensiones contextuales culturales, históricas, económicas, sociales y jurídicas de su territorio.

Ese territorio constituye y es constituido a la vez por las prácticas de los actores en un mundo fluido, en su interacción con el entorno y los otros sujetos; es decir, seres socioculturales, históricos, capaces de constituir sus mundos significativos. Esto permite pensar la comunicación en clave relacional y abordarla "como fenómeno complejo y fluido. Complejo, en tanto presenta múltiples dimensiones (por ejemplo informativa, ideológica interaccional, sociocultural); fluido porque la dimensión comunicativa es una dimensión intermedia y como tal, convoca a un cierto movimiento, se ubica siempre a medio camino entre el fondo y la forma" (Massoni, 2007: 45).

Por esto, en este capítulo nos proponemos construir una realidad de Tucumán y de la agroindustria cañera en la provincia a partir del análisis de datos. Esto nos permitirá conocer las condiciones contextuales en las cuales se gestó la Mesa como organización; desde qué necesidades político-económicas surgió y construyó sus prácticas, en vínculo con los actores no participantes y situaciones en el territorio; además de los escenarios en los que se desenvuelven los procesos comunicacionales desarrollados en y por la Mesa de Gestión.

La herramienta metodológica utilizada para este análisis será la recopilación de materiales, con lo cual se elaborará un mapa de información a partir de documentos escritos del Instituto Nacional de Tecnología Agropecuaria (INTA), el 
Gobierno provincial, el Programa de las Naciones Unidas para el Desarrollo, además de datos del Instituto Nacional de Estadísticas y Censos de la República Argentina (INDEC) y bibliografía sobre el sector cañero.

\section{Presentación de Tucumán}

La provincia de Tucumán, ubicada en el hemisferio sur del continente americano, se sitúa en la región geográfica del Noroeste Argentino, limitando al Norte con Salta, al Este y Sur con Santiago del Estero y al Oeste y Sur con Catamarca.

Políticamente, se divide en 17 departamentos (San Miguel de Tucumán, Burruyacú, Trancas, Tafí del Valle, Tafí Viejo, Yerba Buena, Lules, Famaillá, Cruz Alta, Leales, Monteros, Chicligasta, Simoca, Río Chico, Alberdi, Graneros y La Cocha) y 112 municipios y comunas rurales. Su capital es la ciudad de San Miguel de Tucumán, cuna de la independencia argentina e ícono de la industria azucarera.

La provincia más pequeña y densamente poblada de Argentina cuenta con una superficie de $22.524 \mathrm{~km}^{2}$, lo que representa el $0,81 \%$ de la superficie total del País $\left(3.761 .274 \mathrm{~km}^{2}\right)$. El 50\% está ocupado por cordones montañosos que influyen en el comportamiento de los elementos climáticos, la génesis de los suelos y la disponibilidad de agua subterránea. Estas montañas detienen los vientos húmedos del Atlántico, provocando que se eleven. La condensación de humedad en esta zona provoca lluvias y nevadas sobre las laderas orientales, dando lugar a una abundante vegetación.

De acuerdo a las áreas geográficas, al Este se encuentran las llanuras que forman parte de la región chaqueña. Al Oeste, tres cadenas montañosas: las Cumbres Calchaquíes pertenecientes a la Cordillera Oriental, la Cadena del Aconquija perteneciente a las Sierras Pampeanas y la unión entre estos dos cordones que se produce en el Valle de Tafí. En el Noroeste, se ubica una tercera cadena montañosa: las Sierras de El Cajón o Quilmes, que delimitan los Valles Calchaquíes. Y al Noreste, las Sierras Subandinas representadas por las Sierras de Burruyacú.

La geografía y el clima en estas tierras presentan aptitud para el desarrollo de cultivos como frutales, caña de azúcar, hortalizas y frutas finas en el Pedemonte y la región de la Llanura Chacopampeana; y cultivos de granos de verano (soja, 
maíz, sorgo) y otoño-invierno (trigo, cebada, cártamo, girasol) hacia el Este de la Llanura Chacopampeana; además de la actividad ganadera que también tiene presencia en la Cuenca Tapia Trancas.

Como plantea el INTA (2008:4) en su Plan Tecnológico del Centro Regional Tucumán-Santiago del Estero:

Estos cultivos son acondicionados y/o transformados en una gran cantidad de establecimientos (empaques y fábricas citrícolas, ingenios azucareros, frigoríficos, papeleras, empresas de bebidas, golosinas, frutilleras, entre otros) que tiene la provincia. Esto implica, por un lado, un importante consumo de energía, emisión de residuos, desarrollo de logística y una gran absorción de mano de obra; y, por otro, constituye una oportunidad en tanto reúne muchas de las características favorables de un distrito industrial asociadas a economías de escala, coordinación y organización entre diferentes actores y circulación de intangibles como innovación y conocimiento.

De esta manera, entre las principales actividades agroindustriales se encuentran la caña de azúcar y el limón, que abarcan desde la producción primaria hasta el producto final, pasando por las distintas etapas de procesamiento.

En este sentido, la caña de azúcar se constituye como la principal agroindustria de la Provincia, siendo el rubro económico más importante, dado que hasta la segunda mitad de 1960 la producción de Tucumán estuvo centrada en este monocultivo industrial. El sector cuenta con más de 5.000 productores que abastecen de caña a unos 15 ingenios azucareros distribuidos en diferentes localidades, aportando el 62\% del azúcar producido en el país. Actualmente, además de azúcar, el sector está insertándose en la producción de bioetanol a partir de la caña para cumplir con la normativa nacional № 26.093 que establece la obligatoriedad en el corte de las naftas con un $5 \%$ de biocombustibles.

En las últimas décadas, la producción local se fue ampliando hacia otros cultivos como el limón, favorecidos por la fertilidad de los suelos y las condiciones climáticas, que llevaron a que Tucumán se convierta en la principal productora nacional y mundial de esta fruta, además de la primera industrializadora en el país. El sector ha experimentado un crecimiento anual promedio cercano al $10 \%$ en los 
últimos diez años. Cuenta con unas 25 plantas de empaque, que destinan la mayor parte de su producción a abastecer el mercado internacional con la comercialización de limón fresco y productos derivados como jugos concentrados, cáscaras secas, aceites y pectinas.

Por otra parte, la horticultura ocupa un lugar de relevancia con la producción de lechuga, arvejas, pimientos y chauchas, ubicando a Tucumán como la segunda productora nacional en estos rubros. Otras producciones de importancia, desde el punto de vista económico, son el poroto, soja, maíz, papa, palta, frutilla y arándanos.

Con la agroindustria de estos cultivos, Tucumán aporta un importante porcentaje de la producción del país: es el primer productor y procesador de azúcar y limón; el primer productor de palta y papa primicia; el segundo de frutilla y el tercero de arándanos. Es la primera provincia en producir energía eléctrica y biocombustible a partir de la caña de azúcar en Argentina.

En cuanto al comercio internacional, durante el año 2010, las exportaciones de Tucumán alcanzaron los 903 millones de dólares ${ }^{3}$, lo que representó un crecimiento del $17,7 \%$ respecto del año anterior. El principal comprador de la producción tucumana fue Brasil (17,2\%), seguido por Estados Unidos (15,7\%), Países Bajos $(11,6 \%)$ y China $(7,7 \%)$. Entre los principales productos que se venden al exterior se destacan los cítricos y sus derivados: limones y limas (18,5\%), jugo de cítricos (12,5\%) y aceite esencial de limón (11,5\%). También participan el poroto de soja y el azúcar en bruto con un porcentaje cercano al 7\% del total exportado cada uno.

De esta manera, la provincia se constituye como el primer exportador mundial de jugos, aceites y cáscara deshidratada de limón y el segundo de la fruta fresca; y el primer exportador de frutillas congeladas y arándanos de la Argentina.

Otras actividades que tienen una fuerte participación en la generación de valor son las industrias automotriz, textil, de calzado, golosinas, gaseosas, papel a partir del bagazo de caña, cerveza, productos electrónicos, fósforos, productos lácteos, miel de abeja y melaza de caña.

El Producto Bruto Geográfico (PBG) de Tucumán representa alrededor del $2,1 \%$ del PBI de Argentina. Esto determina que sea la provincia con la mayor economía de la Región del Norte Grande Argentino. Las actividades primarias o

\footnotetext{
${ }^{3}$ Según datos del "Informe Económico: Provincia de Tucumán" de la Cámara Argentina de Comercio, Departamento Economía. Junio de 2011
} 
extractivas aportan el 10,20\% del PBG tucumano; las actividades secundarias o industriales, el 23,80\%; y las actividades terciarias o de servicios, el $66 \%{ }^{4}$.

Esta dimensión económica-productiva se entrecruza con la realidad social de los tucumanos. Veamos, entonces, cuál es la composición social de la Provincia. En cuanto a la población, según los datos del último Censo Nacional, Tucumán tiene 1.448.188 habitantes, con una densidad de $64,30 \mathrm{hab} / \mathrm{km}^{2}$ distribuidos en casi 370.000 hogares. De este modo, nuclea al 3,61\% de la población de Argentina. El mayor porcentaje se concentra en los departamentos de San Miguel de Tucumán y Cruz Alta con 548.866 y 180.499 habitantes, respectivamente. En relación al censo del 2001, el aumento de la población total fue de un 8\% (INDEC, 2011).

Indicadores como salud, educación y calidad de vida se ven reflejados en el índice de desarrollo humano ${ }^{5}$, que es de 0,797 para Argentina, ubicando al país en la posición 45 dentro del grupo «desarrollo humano muy alto» que nuclea a los países desarrollados. La Región Noreste del país es la más rezagada en estos índices. Tucumán se encuentra entre las provincias argentinas más atrasadas en desarrollo humano junto a Formosa, Entre Ríos, Chaco, Misiones y Corrientes.

A pesar de las mejoras en los índices macroeconómicos (funcionamiento del mercado de trabajo, niveles de ingreso mensuales promedios de la población y condiciones de vida) y en las políticas sociales implementadas en el país en el período 2003-2008, en el interior de Tucumán subsisten situaciones de desigualdad, pobreza e indigencia muy extremas.

De acuerdo al INDEC, en el segundo semestre de 2011 la tasa de pobreza ${ }^{6}$ en el Gran Tucumán-Tafí Viejo fue del 7,2\%, es decir, que unos 59.200 habitantes no lograron reunir los fondos suficientes para dejar de ser considerados pobres. De este modo, el $4,5 \%$ de los hogares tucumanos no alcanzaron los casi $\$ 1.400$ mensuales para salir de situación de pobreza. Mientras que la indigencia prácticamente desapareció, ya que afecta sólo al $0,9 \%$ de la población ${ }^{7}$. Sin

\footnotetext{
${ }^{4}$ Los datos corresponden a la Dirección Nacional de Programación Económica Regional del Ministerio de Economía de la Nación.

${ }^{5}$ El índice de Desarrollo Humano de Argentina y Tucumán corresponde al informe publicado por el Programa de las Naciones Unidas para el Desarrollo (PNUD) el 2 de noviembre de 2011, con datos relativos a estimaciones para ese año. Incluye indicadores como salud, educación, ingresos, desigualdad, pobreza, género, sostenibilidad, demografía.

${ }^{6}$ La tasa de pobreza e indigencia se mide a partir de los datos surgidos de la Encuesta Permanente de Hogares $(E P H)$ realizada por el INDEC.

${ }^{7}$ En el caso de la población total de Argentina, el 6,5\% es pobre y el 1,7\% se ubica por debajo de la línea de indigencia.
} 
embargo, la realidad socio-económica de muchas familias rurales y urbanas del interior de la provincia no condice con estas cifras.

Esta situación se ve agravada por la incidencia del creciente índice de inflación. Si bien el INDEC registra una inflación del 10\% entre julio de 2011 y julio de 2012 en el país (con un promedio cercano al 0,8\% mensual), un grupo de diputados de la oposición plantea una inflación del $23,31 \%$ para ese mismo período en base a informes de consultoras privadas.

A esto se suman los graves problemas de desnutrición que sufren muchas familias tucumanas, especialmente los niños con daños irreversibles para su crecimiento. Según datos del Programa Focalizado de Rehabilitación Nutricional, una iniciativa que lleva adelante la cartera de Salud, en el 2010 había 10 mil personas desnutridas en estado crítico, entre chicos y embarazadas, en la Provincia.

Otra de las situaciones que afecta la calidad de vida, según el INTA (2008: 4), tiene que ver con:

El creciente proceso de urbanización registrado en Argentina y, específicamente, en el NOA. Entre 1970 y 2001 la región perdió un alto porcentaje de sus pobladores rurales. En el período 1988-2002 se observa una disminución de $15 \%$ en las explotaciones agropecuarias de la Región NOA. La migración del campo a las ciudades es cada vez mayor, concentrándose la población en cinturones de pobreza y su correlación con problemas sociales (desnutrición y/o malnutrición, desempleo y subempleo, déficit de acceso a la salud y la educación) y ambientales (condiciones insalubres de agua y sanidad, recolección de basura y exposición a contaminantes). La congestión y el sobrepoblamiento devienen entonces en un empeoramiento de la salud general y en una menor calidad (habitabilidad) ambiental.

Estas condiciones políticas, productivas-económicas y sociales de Tucumán constituyen el territorio en el que se desenvuelve la Mesa de Gestión Ambiental de Cruz Alta con sus discursos, prácticas y objetivos. 


\section{Descripción del Departamento Cruz Alta}

Como su nombre lo indica, la Mesa de Gestión Ambiental de Cruz Alta se ubica en dicho departamento, al Este de la provincia de Tucumán. El mismo limita al Norte con el departamento Burruyacú, al Este con la provincia de Santiago del Estero, al Sur con el departamento Leales y al Oeste con los departamentos Lules, Capital y Tafí Viejo.

En una superficie de $1.255 \mathrm{~km}^{2}$, es el segundo departamento más poblado de Tucumán con un total de 180.499 habitantes distribuidos en 2 municipios (Banda del Río Salí y Alderetes) y 13 comunas rurales (Colombres, Delfín Gallo, El Bracho, El Cevilar, El Naranjito, La Florida, Las Cejas, Los Bulacio, Los Pereyras, Los Pérez, Los Ralos, Los Villagra, Luisiana, Ranchillos, San Andrés, San Miguel).

La capital es Banda del Río Salí, donde se sitúa una de las Agencias de Extensión Rural del INTA que lleva el mismo nombre y es sede de las reuniones de la Mesa de Gestión Ambiental de Cruz Alta. La ciudad, además de ser la cabecera departamental, se ubica a sólo 3 km. del conglomerado del Gran San Miguel de Tucumán.

El perfil industrial de la Banda tiene su principal referente que es el ingenio azucarero Concepción. También se encuentra el ingenio San Juan y una gran variedad de empresas de distintos rubros.

En cuanto a la actividad económica del departamento Cruz Alta, en general, se basa en el sector industrial y la agricultura. Importantes empresas industriales se ubican principalmente en el Oeste del mismo. Entre ellas se destaca, además del ingenio Concepción, la planta de la multinacional sueca Scania, la Aceitera General Deheza (AGD) y Refinor (Refinerías del Norte).

En el Este se encuentran, principalmente, plantaciones de caña y otros cultivos en menor medida. Según datos del Laboratorio de Sistemas de Información Territorial del INTA Famaillá (2011), Cruz Alta es el departamento cañero por excelencia, ya que cuenta con la mayor superficie destinada a este cultivo en la provincia, reuniendo cerca del 20.4\%(49.788 ha) del total provincial (244.195 ha). Le siguen Leales con el 18,7\% (45.676 ha) y Simoca con el 14,4\% (35.142 ha). El resto de los departamentos no reúnen más del 7,9\% cada uno. 


\section{La agroindustria de la caña de azúcar}

La actividad del sector cañero en Tucumán, que aporta el $62 \%{ }^{8}$ del azúcar producido en el país, tiene una importante incidencia en las dimensiones sociales, económicas, políticas, culturales y ambientales de la provincia.

Según estimaciones de la Dirección de Estadística de la Provincia de Tucumán (2011), la participación de la actividad productiva vinculada a la caña de azúcar, agregando su incidencia en el Sector Agropecuario y el Industrial, alcanza un $10 \%$ aproximadamente del Producto Bruto Geográfico provincial.

En un trabajo reciente, Jorge Morandi y Jorge Bustos (2011: 5) afirman que:

El área cañera constituye en sí misma un conglomerado tecnológico - social y productivo cuya concentración espacial está claramente definida, en el cual se verifican altos niveles de Integración Ciencia - Industria - Estado y que cuenta con la mayor concentración de equipamiento público de toda la provincia. La actividad agroindustrial azucarera ha sido el motor que ha impulsado el conjunto de procesos sociales que, a lo largo de la historia, han dado como resultante esta configuración del territorio provincial, constituyendo en sí mismo el complejo territorial de mayor preeminencia y por lo tanto, en la consideración del presente trabajo, el "territorio" sobre el cual, un mejoramiento en los estándares de salud ambiental, competitividad productiva, participación social y gestión institucional impactará positivamente no sólo sobre el desempeño económico territorial y la calidad de vida de sus habitantes, sino que, de manera extensiva, esos mismos impactos se proyectan positivamente al resto de la provincia mejorando los niveles de desarrollo alcanzado.

La caña de azúcar es considerada por el INTA como un cultivo industrial. Los cultivos industriales son "aquellos cuyo producto no admite consumo directo o para el que su trasformación resulta mucho más provechosa. Su conexión imprescindible con la industria transformadora de la materia prima supone un fuerte valor agregado, una cierta garantía de estabilidad de la producción y la generación de una

\footnotetext{
${ }^{8}$ Los datos del Centro Azucarero Argentino en base la producción total del año 2011.
} 
fuerte actividad económica y de empleo en el ámbito de las regiones productivas" (Bongiovanni y Giletta, 2012: 1).

La cadena azucarera argentina está concentrada en la región del Noroeste del país (Tucumán, Jujuy y Salta) y, en menor medida, en las provincias del Litoral (Norte de Santa Fe y Misiones). Variables como cantidad de azúcar producida, superficie cultivada y número de explotaciones cañeras e ingenios ubican a Tucumán como el principal productor de azúcar a nivel nacional, con la consecuente incidencia que tiene la actividad para el territorio provincial y regional.

Según datos del Centro Azucarero Argentino (CAA), durante el año 2011 el sector azucarero produjo un total de 1.945.047 toneladas $(\mathrm{t})$ de azúcares, de las cuales 1.716.223 t corresponden a azúcar blanco (destinada al consumo directo) y 228.823 t a azúcar crudo (aquella cuyo destino final es la exportación). Tucumán tuvo una participación del $62 \%$ en ese total, con una producción de 1.199.522 t. Le siguieron Salta y Jujuy con 727.028 t, aportando el 37\% del total del país.

El cultivo en Argentina se desarrolla en una superficie de alrededor de 300.000 ha. Tucumán concentra cerca del $80 \%$ de esa cifra. Datos del Laboratorio de Sistemas de Información Territorial del INTA Famaillá indican que la superficie con este cultivo en la provincia fue de 244.195 ha. en el 2011. La mayor producción (64\% del total provincial) tuvo lugar en los departamentos de Cruz Alta, Leales, Simoca y Monteros ${ }^{9}$.

Una de las cuestiones más importantes a tener en cuenta, considerando que podría incrementar los problemas ambientales generados por la actividad, es la creciente expansión de la superficie destinada al cultivo de la caña. En el 2011, el área cultivada en Tucumán creció un 13.75\% en relación al 2010.

Algunos autores reconocen que la mejora en la rentabilidad de la actividad azucarera y las crecientes expectativas en el mercado de los biocombustibles produjeron un importante aumento del área plantada con caña, desplazando a cultivos anuales tradicionales como la soja en cerca de 30.000 ha. "Los departamentos donde se registró un incremento significativo en términos absolutos fueron Leales, Cruz Alta, Burruyacú, Alberdi y Simoca. Estos cinco departamentos

\footnotetext{
${ }^{9}$ Las áreas ocupadas con caña de azúcar fueron identificadas mediante técnicas de teledetección con datos adquiridos a través de sensores remotos colocados a bordo de plataformas satelitales. Actualmente, esta herramienta es la más adecuada para este tipo de estudios por su alto grado de precisión y bajo costo. Trabajo del Laboratorio de Sistemas de Información Territorial del INTA Famaillá.
} 
explican el $85 \%$ del aumento en la superficie cultivada con caña en la provincia" (Sopena, Benedetti y Ríos, 2011: 27).

Gráfico 1: Superficie ocupada con caña de azúcar durante el 2011. Laboratorio de Sistemas de Información Territorial del INTA Famaillá

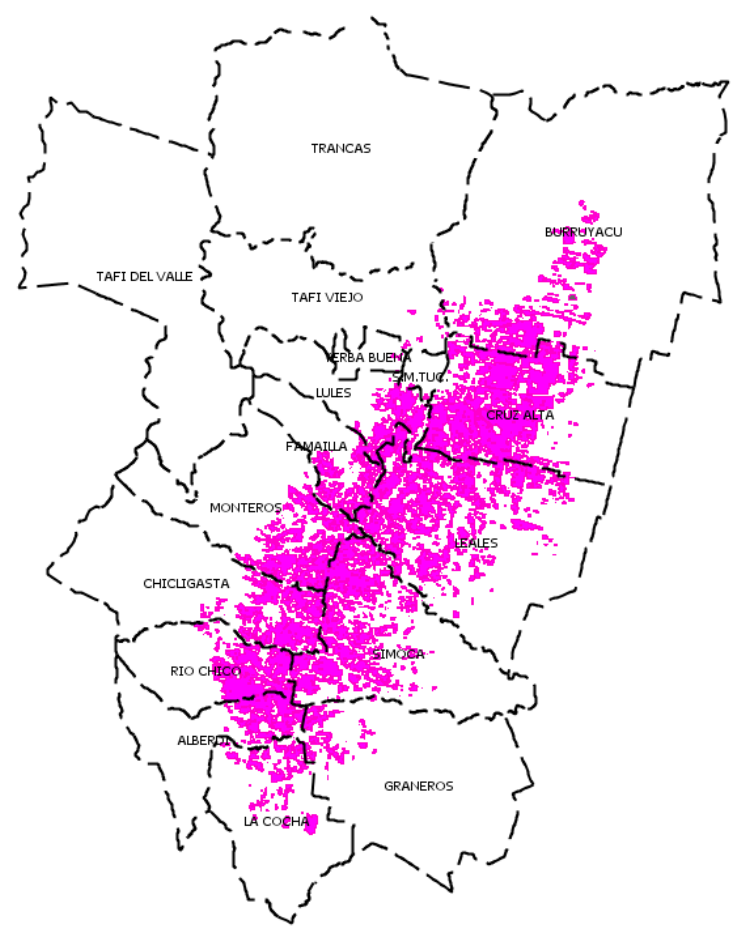

A diferencia de lo que ocurre en Salta y Jujuy, donde los ingenios son propietarios de la mayor parte de la materia prima, en Tucumán predomina una estructura con una gran cantidad de productores (más de 5.000) que venden su caña a los ingenios. Entre ellos se encuentra una amplia gama que va desde el pequeño minifundista hasta las grandes empresas agropecuarias, cada uno con situaciones económicas, sociales, productivas y tecnológicas muy diferentes.

De acuerdo al Censo Nacional Agropecuario 2002, Tucumán contaba con 5.364 Explotaciones Agropecuarias (EAPs) cañeras en un área plantada de 168.662 ha en ese año. Con estos datos ${ }^{10}$, Jorge Morandi, Liliana Ríos y Gonzalo Pérez (2012a: 12-13) caracterizan las EAPs cañeras de la provincia, introduciendo

${ }^{10}$ Según los autores, dada la carencia de información actualizada, se utilizaron los datos estadísticos del Censo Nacional Agropecuario 2002. Si bien se trata de información con casi 10 años de antigüedad, se estima que la estructura productiva del subsector primario en la provincia no se ha modificado sustancialmente. En algunos casos esta fuente se complementó con datos del Registro de Productores Cañeros de la provincia. 
variables como nivel tecnológico y rendimientos, formas de comercialización y conformación socioeconómica de las unidades productivas. Considerando la superficie plantada con caña, dividen a las EAPs en tres grandes grupos:

- Grupo 1. Pequeños productores (de 0,1 a 50 ha de caña): este grupo concentra 4.879 EAPs $(90,1 \%$ del total provincial), con una superficie total de 46.961 ha ( $28 \%$ de la provincia). Comprende desde productores minifundistas (hasta 10 ha de caña) que practican una agricultura de subsistencia, con bajo nivel tecnológico (no disponen de maquinarias ni capital de trabajo y no practican ningún tipo de gestión empresarial), utilizan fuerza de trabajo exclusivamente familiar, y complementan el ingreso de la venta de caña con la autoproducción de alimentos (huerta, gallinas y/o cerdos) y con ingresos extraprediales (trabajo eventual y/o planes sociales); hasta productores familiares más o menos diversificados (de 10 a 50 ha), con niveles de capitalización y nivel tecnológico bajo a medio (disponen de maquinarias antiguas y obsoletas y practican una gestión empresarial con bajo nivel de especialización), y utilizan fuerza de trabajo familiar con contratación eventual de asalariados en ciertas etapas del ciclo productivo. El rendimiento cultural de estas fincas se encuentra en el orden de las $50 \mathrm{t}$ de caña/ha, mientras que el rendimiento fabril es de alrededor del $8 \%$. Los principales problemas comunes de los productores de este Modelo 1 son: la baja escala de producción, la carencia de equipamiento, los bajos rendimientos, la informalidad fiscal, y la falta de acceso a los servicios de seguridad social y previsional.

- Grupo 2. Medianos productores (de 50,1 a 500 ha de caña): engloba a 444 EAPs (8,3\% del total provincial), con una superficie total de 60.969 ha $(36,15 \%$ de la provincia). Está integrado por cañeros medianos que practican una agricultura típicamente comercial (a veces diversificada con citrus, soja o cereales), con un nivel de medio a alto en tecnología y mecanización; con rendimientos culturales que se ubican alrededor de las 70 t de caña/ha., y con un rendimiento fabril de aproximadamente $9 \%$. Dado que es un tipo de productor que invierte en tecnología e insumos, se encuentra en situación vulnerable, debido a que ante mínimas variaciones en el precio del producto o de los insumos, corren el riesgo de quedar al borde del quebranto. Por otro lado, no siempre disponen de un fácil 
acceso al crédito, aunque teóricamente tienen capacidad de endeudamiento. En la comercialización, debido a su alto grado de formalidad fiscal, los productores de este Modelo 2 tienen una relación directa con los ingenios, con lo cual no necesitan recurrir a los intermediarios. Los servicios de plantación, cultivo y cosecha se realizan con fuerza de trabajo asalariada o a través de contratistas.

- Grupo 3. Grandes productores (más de $\mathbf{5 0 0}$ ha de caña): integra a 41 EAPs $(0,7 \%$ del total provincial), con una superficie total de 60.732 ha (36\% de la provincia). En su mayoría son grandes empresas agropecuarias e ingenios azucareros que practican una agricultura empresarial casi siempre diversificada (soja, citrus y cereales), con un nivel alto en tecnología y mecanización; con rendimientos de alrededor de 80 t/ha de caña; y un rendimiento fabril del orden del $10 \%$. Presentan condiciones muy favorables para acumular capital. Los servicios de plantación, cultivo y cosecha se realizan con equipamiento y logística propia (cosechadoras integrales y un parque de maquinaria completo y moderno). Los problemas de los productores de este Modelo 3 se encuentran principalmente en las formas de contratación de personal y a veces en la comercialización.

En el caso de los pequeños y medianos productores, muchos se encuentran asociados a cooperativas y otras formas organizativas para enfrentar las dificultades tecnológicas y económicas a la hora de producir y comercializar su caña. Es importante tener en cuenta estos problemas ya que, como veremos más adelante, una de las principales limitantes para erradicar la quema es que este segmento productivo aún no cuenta con la tecnología que permita dejar de utilizar esta práctica.

Son cuatro las asociaciones gremiales que representan a los productores cañeros tucumanos: la Unión Cañeros Independientes de Tucumán (UCIT), el Centro de Agricultores Cañeros de Tucumán (CACTU), la Unión de Cañeros del SUR (UCS) y Cañeros Unidos del Este (CUE). Éstos últimos participan en la Mesa de Gestión Ambiental de Cruz Alta.

En el caso de los trabajadores del campo, son representados por la Federación Obrera Tucumana de la Industria Azucarera (FOTIA). En la provincia existen alrededor de 20.000 trabajadores vinculados a la producción primaria, de los cuales más de la mitad no se encuentra registrado laboralmente. "Generalmente los 
productores e ingenios que contratan trabajadores lo hacen en forma temporaria o a través de empresas tercerizadas, por lo cual estos trabajadores no sólo carecen de estabilidad laboral, sino que también pierden el beneficio de los planes interzafra ${ }^{11}$ [...] Otro de los problemas que enfrentan los trabajadores es la falta de control estatal de los aportes previsionales y de la seguridad social que deben hacer los empleadores" (Morandi, Ríos y Pérez, 2012b: 22-23).

En el proceso de cosecha del cultivo, los productores utilizan tres sistemas que, como veremos más adelante, tienen una relación directa con la utilización de la quema: la manual y la semi-mecánica, donde se quema la caña, y la mecanizada integral, donde se pueden quemar las hojas -maloja o rastrojo- y otros residuos ${ }^{12}$ que quedan en el campo para plantar o cultivar.

En cuanto al sector industrial, de los 23 ingenios azucareros que producen el 100\% del azúcar del país, Tucumán cuenta con 15 de ellos (Aguilares, Bella Vista, Concepción, Cruz Alta, La Corona, La Florida, La Fronterita, La Providencia, La Trinidad, Leales, Marapa, Ñuñorco, San Juan, Santa Bárbara y Santa Rosa) con diferentes niveles de desarrollo tecnológico.

El personal del sector industrial se encuentra agrupado en dos cámaras gremiales empresarias: el Centro Azucarero Argentino (CAA) y el Centro Azucarero Regional Tucumán (CART). La mayor parte de los trabajadores industriales están asociados a FOTIA; mientras que la organización sindical Federación de Empleados de la Industria Azucarera (FEIA) nuclea en su mayoría a los empleados administrativos y personal técnico.

La negociación comercial entre el sector productivo y el industrial se realiza a través del sistema de maquila, de acuerdo a la Ley 25.133/99. De este modo, el productor entrega su caña al ingenio y recibe a modo de pago bolsas de azúcar, que luego vende por su cuenta al mercado. Por su parte, el ingenio se queda con un porcentaje del azúcar, además de otros subproductos como la melaza y el bagazo ${ }^{13}$. Si bien las proporciones en el reparto del azúcar varían en cada caso, en general predomina la distribución de un 58 a $60 \%$ para el cañero y un 40 a $42 \%$ para el ingenio.

\footnotetext{
${ }^{11}$ Los planes interzafra son otorgados por el Gobierno Nacional para compensar la falta de ingresos familiares durante el período durante el cual quedan desempleados los obreros.

${ }^{12} \mathrm{Se}$ considera residuos agrícolas de cosecha a las vainas y cogollos en peso fresco que quedan en el campo después de la cosecha.

${ }^{13}$ Un porcentaje del bagazo es utilizado como fuente de energía para el funcionamiento de las calderas del ingenio y otro es vendido a las empresas papeleras. La melaza sirve para la producción de alcohol.
} 
Estos datos demuestran que la actividad azucarera en Tucumán es uno de los principales pilares de la economía provincial, pero el impacto ambiental que tiene en la actualidad genera fuertes presiones de la sociedad, lo que podría condicionar su futuro. La quema de caña de azúcar durante la cosecha y post cosecha es una práctica común en Argentina y en los principales países productores de este cultivo, causando problemas ambientales, sanitarios y de infraestructura. 
La organización a diagnosticar en nuestra tesis, llamada Mesa de Gestión Ambiental de Cruz Alta, se constituyó como tal para trabajar sobre una problemática específica de Tucumán: la quema en el cultivo de la caña de azúcar.

La utilización de la quema como método auxiliar de la cosecha se vincula con cuestiones sociales, económicas, productivas, tecnológicas, históricas y culturales que hacen a la idiosincrasia del sector cañero en su territorio.

Por ello, en este capítulo nos proponemos continuar con el recorrido contextual de nuestra investigación y construir una realidad de la problemática a partir de su historicidad en la provincia, las consecuencias que genera, la legislación que prohíbe esta práctica y las alternativas tecnológicas que se desarrollan para erradicarla.

La herramienta metodológica que utilizaremos para hacerlo será la recopilación documental para trabajar con bibliografía de algunos autores y los documentos de las leyes y sus decretos reglamentarios. El objetivo es construir un mapa de información a partir de los documentos susceptibles de ser utilizados en la investigación.

También realizaremos entrevistas semi-estructuradas para conocer la mirada de los actores vinculados a la problemática. Esta técnica se realiza en el mismo entorno donde los sujetos desarrollan su vida cotidiana y acontecen las situaciones problemáticas de la organización. "La entrevista es una situación cara a cara donde se encuentran distintas reflexividades pero, también, donde se produce una nueva reflexividad. Entonces la entrevista es una relación social a través de la cual se obtienen enunciados y verbalizaciones en una instancia de observación directa y de participación" (Guber, 2001: 76). "En un trabajo de campo la entrevista suele tener lugar en ámbitos familiares a los informantes, pues sólo a partir de sus situaciones cotidianas y reales es posible descubrir el sentido de sus prácticas y verbalizaciones" (Guber, 2001: 98).

\section{Historicidad de la quema como método auxiliar de la cosecha}

La quema durante el proceso de producción del cultivo es utilizada, desde la década de 1960 aproximadamente, para eliminar las hojas -maloja o rastrojo- que 
envuelven a la caña y otros residuos que quedan en el campo después de la cosecha, considerados basura.

Los productores utilizan dos tipos de quema en el cultivo, dependiendo del sistema de cosecha empleado. Cuando se realiza la cosecha en forma manual o semimecanizada, la caña es cortada, apilada en el suelo y quemada para eliminar las hojas, ya que el ingenio no recibe las cañas con la maloja. También se quema la caña en pie, es decir, antes de cortarla para facilitar todo el proceso posterior.

La quema también es usada con el sistema mecanizado integral, pero en este caso es posterior a la cosecha. Al cortar y pelar la caña, la maquina deja la maloja y otros residuos sobre la superficie del suelo, que se queman por diferentes razones: cultivar el suelo, renovar el cañaveral o mejorar el crecimiento de la caña durante la próxima campaña.

Entonces, para comprender el uso del fuego como herramienta de producción, es necesario conocer cómo se fue utilizando con la evolución de los sistemas de cosecha a lo largo de la historia de la agroindustria cañera en la Provincia.

Hasta la década del 60' la cosecha era predominantemente manual y no se quemaba la caña ni la maloja. En un trabajo muy pesado físicamente, el obrero se encargaba de cortar la caña con un machete; pelarla para eliminar las hojas, lo que evitaba el uso de fuego; despuntar para quitar la porción inmadura del tallo; y, por último, apilar y cargar en carros de baja altura para ser trasladada al ingenio. Lo que se hacía en ese momento con la maloja que quedaba en el campo era acordonarla a los costados del surco, picarla con los discos e incorporarla al suelo.

Nemesio Cuello ${ }^{14}$, que comenzó a trabajar como cosechero de caña a los 19 años en esa época, lo recuerda así: "Todo se pelaba. La maloja se sabía encordonar en el surco, vos sabes lo que era la tierra, bien cultivada, porque los discos la picaban bien. Para el siguiente año era una manteca la tierra. Se la dejaba al costadito del surco y venían los discos y la picaban. La engordaba a la tierra. Era un hermoso cañaveral por el abono. No se quemaba. En esos tiempos era prohibido quemar".

Considerando los tiempos empleados por las obreras y obreros para realizar cada tarea, "las de pelar y despuntar eran las que más tiempo demandaban y las

\footnotetext{
${ }^{14}$ Entrevista personal, 15 de septiembre de 2012
} 
más costosas, ya que ocupaban el 69,18\% de la jornada laboral normal de 8 horas" (Morín, 1971, citado por Fogliata, 1995: 327). Además, el pelado era una operación dura que implicaba un desgate físico muy grande para el obrero.

La crisis de los años 60' y la bonanza en el mercado azucarero en la década del 70' llevó a que los cañeros comenzaran a introducir máquinas cosechadoras para abaratar los costos de producción. "Pues el rubro cosecha involucra aproximadamente el $50 \%$ del costo total para producir una tonelada de caña" (Fogliata, 1995: 299).

De este modo nació el sistema de cosecha semi-mecánico en Argentina, que alterna el empleo de la maquinaria con el hombre, lo que implicó una fuerte reducción de la mano de obra ocupada en ese momento. El proceso consiste en cortar a máquina; pelar, despuntar y apilar manualmente; y, por último, cargar a máquina.

Con la introducción de estos equipos se comenzó a reemplazar la tarea de pelar por el uso de la quema para reducir costos, lo que permitió también disminuir el desgaste físico del obrero. Franco Fogliata (1995: 328) explica que "cuando la caña es quemada y se evita pelar, el rendimiento de un obrero se eleva a unos $5.000 \mathrm{~kg} / \mathrm{día}$, pero si el despuntado no es muy exigente, el rendimiento es aún mayor. Puede hacer 10 a 12 t/día si el obrero acondiciona y despunta caña quemada, siendo el corte y la carga mecánica".

La quema en este sistema se realiza de dos maneras. La más utilizada es aquella donde se corta y apila la caña el surco, se prende fuego y después se carga la caña quemada a los carros para ser trasladada al ingenio.

El otro tipo de quema, menos habitual en la actualidad, es cuando al cañaveral se le enciende fuego "en pie", es decir, antes de cortar la caña. De esta forma los tallos quedan libres de hojas, lo que facilita todo el proceso de cosecha. Pero es una quema muy peligrosa porque la intensidad de las llamas vuelve más incontrolable el fuego.

Es importante considerar que una vez transcurridas las 24 o 48 horas de producida la quema de la caña, se deteriora la calidad del jugo, generando pérdidas en la producción de azúcar. Por lo tanto, los productores deben realizar la quema de manera planificada de acuerdo a la asignación diaria de materia prima que debe entregarse al ingenio. 
Actualmente, la cosecha semi-mecánica es utilizada especialmente por los pequeños productores de menos de 50 hectáreas, que ocupan el $28 \%$ de la superficie cultivada con caña en Tucumán. Los medianos y grandes también la usan en algunos de sus lotes donde la cosechadora integral no puede ingresar por problemas de superficie.

Otra de las alternativas de cosecha comenzó en la década del 70 con la introducción de las primeras cosechadoras integrales en el NOA y en la década de 1980-90 ya operaban varias máquinas importadas y nacionales en Tucumán. De este modo, se fue consolidando el sistema de cosecha mecanizada integral, donde todo el proceso (corte, pelado, despunte y carga) es realizado por la máquina, lo que permite cosechar la caña en verde, es decir, sin quemarla.

Sin embargo, sólo los productores medianos y grandes pudieron acceder a estos equipos por dos cuestiones: una económica, debido a los altos costos de estas cosechadoras, y otra productiva, dado que en los predios de pequeñas superficies estas máquinas no pueden circular.

Si bien este sistema permitió que se dejara de quemar la caña en el proceso de cosecha, no logró solucionar el problema de la maloja que queda en el campo y es quemada a la hora de la renovación anual del cultivo o la plantación de caña nueva ${ }^{15}$. "Después de la recolección mecanizada, se dejan en superficie aproximadamente entre 15 y 25 t/ha de residuos agrícolas de cosecha" (Anschau, Sopena, Benedetti y Valeiro, 2011: 45). Se trata de una importante masa vegetal altamente combustible.

Así lo grafica Ignacio Lobo Viaña ${ }^{16}$, productor cañero y ex funcionario del gobierno provincial: "la quema del rastrojo como herramienta de producción se hace por dos razones fundamentales: para poder despejar los campos y volverlos a plantar, porque si uno mete un equipo con toda la maloja que está ahí después no puede preparar bien los suelos y plantar; o para poder cultivar. Para cultivar caña ya hay herramientas que permiten cultivar con rastrojo, son equipos que los va incorporando gente que tiene la capacidad económica u obristas que uno los contrata y hacen los trabajados de incorporación del rastrojo".

A pesar de que en algunos lotes se deja parte del rastrojo como cobertura para proteger al suelo de la pérdida de humedad o bien se pica e incorpora como

\footnotetext{
${ }^{15}$ La plantación de caña nueva se realiza cada 4 o 5 años para renovar completamente el cultivo.

${ }^{16}$ Entrevista personal, 9 de agosto de 2012.
} 
mejorador del suelo con máquinas especiales, la mayor parte de los productores lo quema por diferentes razones. Cristina Biaggi y Alejandro Valeiro (2012: 3) lo explican de la siguiente manera:

En parte de la provincia, los/as productores/as lo queman argumentando que el rastrojo no cumple la función de preservar la humedad y que no deja que se acumule temperatura para la próxima brotación. También ocurre que no tienen la maquinaria adecuada para incorporarlo o consideran que la próxima soca de caña de azúcar va a nacer mejor y más rápido si recibe la insolación en forma directa. Otros deciden quemarlo porque temen que al no hacerlo cuando aún la nueva caña no nació, exista el riesgo de que esta maloja igualmente se queme por fuegos que se escapan de lotes cercanos o provocados por terceros y que se retrase o pierda el cultivo si la quema se produce cuando la caña ya brotó.

Por último, es importante considerar que a la quema utilizada como herramienta de producción se suman las quemas accidentales o intencionadas por parte de personas ajenas a las explotaciones cañeras. Esto provoca quemas incontroladas o incendios con el riesgo que significa para la salud de la población, los posibles accidentes en rutas y los incendios en infraestructuras cercanas; además de las dificultades que se generan para los productores que deben acelerar la cosecha en esos lotes por el deterioro de la caña quemada e, incluso, pueden llegar a perder o retrasar la cosecha si se quema el cultivo cuando ya brotó.

\section{Consecuencias del uso del fuego}

Decíamos, entonces, que la práctica de la quema en el cultivo causa problemas ambientales, sanitarios y de infraestructura, generando una fuerte presión de la sociedad sobre el sector productivo al responsabilizarlo por la contaminación que genera dicha actividad.

De acuerdo al Artículo 1ำ de la Resolución № 294/89 del Consejo Provincial de Salud de Tucumán, entendemos por contaminación la presencia en la atmósfera de cualquier agente químico, físico o biológico o de la contaminación de los mismos, generados por la actividad humana, en concentraciones y tiempos tales que puedan 
ser nocivos para la salud o perjudiciales para la vida animal o vegetal, que afecten los bienes materiales del hombre o de la comunidad, que impiden el uso y goce de las propiedades y lugares de recreación o interfieran en su bienestar.

Diversos autores coinciden en que la combustión del material vegetal contamina la atmósfera, favorece las pérdidas de carbono y nitrógeno del suelo, causa problemas en la salud de la población, provoca daños en los tendidos eléctricos, accidentes en las rutas o caminos rurales e incendios que pueden llegar hasta viviendas cercanas, escuelas, hospitales, cultivos ajenos y otros lugares de fácil combustión.

Como plantea el Ministerio de Agricultura, Ganadería y Alimentación de Guatemala (2005, citado por Benedetti y Valeiro, 2012: 64), "durante el proceso de quema, además de agua y dióxido de carbono (CO2), otros elementos son liberados a la atmósfera como, por ejemplo, monóxido de carbono $(\mathrm{CO})$, metano $(\mathrm{CH} 4)$, óxidos de nitrógeno (NO y NO2), ozono (O3) y partículas sólidas. Las consecuencias del fuego van desde pérdidas de la biodiversidad a contaminación ambiental producto del humo, entre las alteraciones inmediatas, mientras que a mediano y largo plazo puede producir erosión, desertificación y enfermedades respiratorias a los seres humanos".

En cuanto a los daños ocasionados específicamente sobre al suelo, la quema de caña produce su mineralización y la muerte de las bacterias nitrificantes (Barrionuevo, Hidalgo y Meoni, 1993).

En lo que respecta a la salud de la población, la incidencia de enfermedades respiratorias se incrementa durante el periodo de zafra. "La máxima concentración de partículas PM10 coinciden con los periodos de incremento de enfermedades respiratorias [...] La principal fuente de emisión de material particulado en la zona de estudio es la quema de caña. El modelo de dispersión muestra que la zona de impacto de la emisión de partículas por quema de caña afecta una distancia de 50 $\mathrm{km}$ de la fuente, llegando el material particulado hasta la Ciudad de Puebla" (Ruiz Reyes y Arroyo Porras, 2007: 23).

Los principales problemas causados son las enfermedades respiratorias y los daños en la vista producto de los gases que se liberan con el humo de la quema. El doctor Fernando Velloso Colombres ${ }^{17}$, médico del Hospital Los Ralos ${ }^{18}$, dice que

${ }^{17}$ Entrevista personal, 11 de abril de 2011. 
"mi trabajo como médico comunitario en la zona rural me ha llevado a vivir lo que es la quema indiscriminada de caña y las enfermedades que he visto en la comunidad por este flagelo que está sucediendo en Tucumán. La quema de caña trae diversos inconvenientes a nuestra salud, sobre todo en niños y ancianos. En nuestro sistema ocular: conjuntivitis, conjuntivitis alérgica y el ingreso de cuerpos extraños. En nuestro sistema respiratorio: síndromes bronquiales obstructivos, asma bronquial y, como consecuencia, algunas enfermedades infecciosas. Además de los perjuicios económicos que trae a las familias de bajos recursos por tener que comprar medicamentos".

Los síntomas de intoxicación con humo son mareos, dolor de cabeza, náuseas y somnolencia. Por ello, si una persona que se encuentra cerca de una quema de caña presenta alguno de estos síntomas, los médicos recomiendan retirarla inmediatamente de ese ambiente y llevarla al centro de salud más cercano.

En este sentido, el Comité de la Asamblea de la Salud Ambiental y Ocupacional de la Sociedad Torácica Americana (1996) sostiene que los principales efectos a corto plazo de la contaminación atmosférica sobre la salud se centran en el aumento de la mortalidad total por causas específicas, el incremento de ingresos hospitalarios y consultas externas, alteraciones de diferentes índices funcionales pulmonares, así como también incremento de los síntomas de enfermedad y del uso de fármacos.

A diferencia de la contaminación atmosférica y del suelo y de los daños en la salud de la población, que son menos 'visibles' o bien resulta más difícil comprobar la relación de causalidad directa de la quema de caña como 'único' responsable de causarlos, los cortes de suministro eléctrico, los accidentes de tránsito y los incendios de infraestructuras a causa de esta práctica son hechos más aislados que, cuando ocurren, generan un fuerte impacto en la sociedad, endureciendo los reclamos de soluciones al sector y a las autoridades gubernamentales.

Si bien no existen cifras oficiales, los accidentes de tránsito a causa de las quemas se convierten en noticia en los medios de comunicación locales todos los años, debido a que el humo producido por el fuego dificulta la visibilidad en rutas y caminos rurales. Las principales rutas que comunican a las localidades del interior

\footnotetext{
${ }^{18}$ En el mes de agosto de 2009, la localidad de Los Ralos vivió un importante incendio a causa de la quema de cañaverales, que provocó que muchas familias sufrieran intoxicación con humo, pérdida de sus viviendas y falta de luz y agua durante varios días. El 2009 fue el año en el que se incrementó la quema en un $95 \%$ en la Provincia, dato al cual se hace referencia en la página 54 de la tesis.
} 
con la capital tucumana, que son muy transitadas, se encuentran rodeadas por cañaverales que forman parte del paisaje que acompaña a los conductores durante la mayor parte de su viaje. La ruta y los cañaverales están apenas separados por las banquinas, por lo que el humo de la quema, por más bajo que sea, llega fácilmente al camino impidiendo la visibilidad de los automovilistas. En el caso de los caminos rurales el peligro es aún mayor, ya que la caña se encuentra mucho más cerca de los vehículos.

Otro de los problemas se relaciona con que los campos plantados con caña están atravesados por tendidos eléctricos. Lo que se constituye en el lote es la servidumbre de paso, pagada por el Estado Nacional, y las empresas de energía firman un convenio con el propietario que establece que puede plantar cualquier cultivo debajo de la línea que no supere los 4 metros, pero no puede quemar. El riesgo es que el humo que emana de una quema puede alcanzar los tendidos y generar cortes en el suministro, dejando fuera del sistema interconectado a parte de la provincia, la región o el país; además de provocar incendios en otras áreas debido al efecto de la alta combustibilidad. Esto ocasiona grandes daños y pérdidas para la sociedad, fundamentalmente, y las empresas concesionarias de energía.

En este sentido, el Ing. Juan Izquierdo ${ }^{19}$, técnico de la empresa de energía eléctrica TRANSENER e integrante de la Mesa de Gestión, explica que "el fuego se transforma en un cable a tierra para nuestra línea. La energía va pasando, son unos 500 mil vol. que van pasando, cuando la quema de caña aparece hace descarga a tierra y la energía que está pasando entre estación y transformadora vuelve inmediatamente, pega en unas tipos de llaves térmicas nuestras, pasa a los transformadores $y$, si es demasiada la energía que vuelve, puede romper un generador. Esto provoca inmediatamente la salida de servicio de la línea. Dependiendo de la cantidad de energía que la línea lleve en ese momento, es lo que repercute en las estaciones transformadoras o en los generadores y puede hacer caer todo el sistema eléctrico".

En cuanto a las pérdidas, Izquierdo sostiene que "para nosotros la mayor pérdida es que la gente común se queda sin energía, no hay que olvidarnos de que más allá de que una casa se quede sin luz, lo hace un hospital, un quirófano, laboratorios médicos, que son cuestiones muchos más graves. Aparte de los costos operativos que significa saber qué sucedió y después, en el supuesto caso de que

\footnotetext{
${ }^{19}$ Entrevista personal, 18 de octubre de 2012.
} 
se rompa algún aparto, eso hoy cuesta mucho dinero. A nosotros, el Ente Nacional Regulador de la Electricidad nos multa por el tiempo de indisponibilidad que esa línea tenga, dependiendo de la gravedad del evento es la multa que después nos aplica, y vamos cumulando penalidades, lo que puede generar que nos quiten la concesión".

Con respecto a los daños causados sobre infraestructuras cercanas a los cañaverales, el Manual de Procedimiento para efectuar una quema de la Asociación de Cultivadores de Caña de Azúcar de Colombia (2004) indica que uno de los mayores peligros de esta práctica es que se pueden provocar quemaduras por hojas encendidas transportadas por el viento. Al prender fuego se puede ocasionar un incendio y el fuego puede propagarse a las zonas aledañas. La peligrosidad debe evaluarse con base en la distancia y accesibilidad a las áreas, el estado de las suertes, la cercanía a cultivos ajenos, viviendas, instalaciones o lugares de fácil combustión.

Haciendo referencia específicamente a estos riesgos, el Decreto $N^{\circ} 795 / 3^{20}$ reglamentario de la Ley $n^{\circ} 7459$ que prohíbe la quema de vegetación en la Provincia, en su Artículo 9ำ establece que queda prohibida, sin excepción, la quema de caña de azúcar en los siguientes casos:

a) En un radio de 1 (un) Kilómetro desde los bordes urbanos;

b) En la zona de dominio de los cables de alta tensión que comprende una franja de 12 metros a cada lado de la línea de conducción;

c) En un radio de 500 (quinientos) metros alrededor de las subestaciones de energía eléctrica de concesionarias;

d) En un radio de 1 (un) kilómetro desde el borde perimetral de los aeropuertos y aeródromos;

e) En un área dentro de 100 (cien) metros a cada lado de la franja de dominio de rutas nacionales o provinciales, y de red ferroviaria;

f) En un radio de 500 (quinientos) metros alrededor de las áreas protegidas;

\footnotetext{
${ }^{20} \mathrm{Si}$ bien el decreto establece que la quema será admitida excepcionalmente y de manera transitoria a los productores minifundistas menores de 50 hectáreas, en tanto se dé cumplimiento con un plan de erradicación progresiva, este permiso excluye la quema en los seis casos mencionados en el Artículo 9.
} 


\section{Legislación vigente}

Para comprender cómo se encuentra legislada la prohibición de la quema de caña en Tucumán, es necesario distinguir lo que es la legislación nacional y la provincial. El Congreso de la Nación es el que tiene la competencia de dictar los códigos de fondo que rigen en todo el país, como puede ser el Código Penal, donde se determina qué es un delito. Y las Legislaturas provinciales son las encargadas de dictaminar las leyes procesales que determinan cómo se va a proceder ante ese delito en cada provincia.

Se trata de diferentes legislaciones que ante la infracción del delito al cual hacen referencia implican distinto tipo de responsabilidad y sanción, que puede ser penal o administrativa. Por ejemplo, si una persona comete un delito establecido en una ley del Código Penal interviene el poder judicial (la policía, la fiscalía y un juez) y se inicia un proceso penal que puede tener penas como la prisión o reclusión. Mientras que en el caso de incumplir con una conducta establecida en una ley procesal interviene la autoridad administrativa provincial, como puede ser alguna dependencia del Poder Ejecutivo, y se aplican sanciones administrativas como multas, inhabilitación en un registro, entre otras.

Entonces, como veremos a continuación, la sanción ante una quema de caña puede implicar una multa administrativa aplicada por la Provincia, por un lado, y una pena de prisión para el responsable del delito de acuerdo al Código Penal por otro.

El Art. 186 del Código Penal establece que aquella persona que cause incendio, explosión o inundación será reprimido:

$1^{0}$ Con reclusión o prisión de tres a diez años, si hubiere peligro común para los bienes;

2ำ Con reclusión o prisión de tres a diez años el que causare incendio o destrucción por cualquier otro medio... b) De viñas, olivares, cañaverales, algodonales, yerbatales o cualquier otra plantación de árboles o arbustos en explotación, ya sea con sus frutos en pie o cosechados. 
La Dra. Florencia Sayago ${ }^{21}$, abogada de la Secretaría de Medio Ambiente del Gobierno de Tucumán e integrante de la Mesa de Gestión, explica que en este código "el bien jurídico protegido es la seguridad pública. Por este artículo consultamos con jueces de instrucción y fiscales para ver si la quema de caña como método de cosecha encuadra acá y recibimos las dos respuestas. Para algunos fiscales si entra en el segundo ítems, aunque sea el mismo propietario el que quema para la cosecha, porque siempre puede causar un daño y poner en riesgo la seguridad pública aunque no sea su intención. Otros plantean que no entra porque si el productor quema su campo para cosechar no tiene la intención de causar destrucción, ya que se habla de destrucción cuando hay intención, dolo o culpa de causar un daño. Ahí entraría la quema vandálica, cuando alguien externo produce la quema, y también la culposa cuando sabés que podés causar un daño e igual lo hacés".

Pero, otros actores consideran que es muy difícil la aplicación de este artículo del Código Penal en la quema de caña por la dificultad que implica determinar la relación de causalidad entre el fuego y el daño ocasionado. Sebastián Malizia $^{22}$, abogado de la Defensoría del Pueblo de Tucumán e integrante de la Mesa, plantea que "para que se aplique el Código Penal tiene que haber una serie de cosas, como es un daño comprobado y una persona que esté reclamando sobre ese daño. Si hay un productor que prende fuego su caña o rastrojo y hay humo, más allá de que un estudio médico pueda decir que una persona tiene una serie de afecciones provocadas por el humo, lo que hay que probar es la conexión entre ese evento y el daño, lo cual es imposible. Porque no puedo agarrar una persona y decir que está enferma por el humo que está ahí, a menos que este asfixiada o quemada con ese fuego y lo puedas vincular. Yo creo que la aplicación del Código Penal en este caso es muy difícil. De hecho, las denuncias radicadas en la justicia penal siguen ahí, no avanzan, porque es muy difícil probar esa relación de causalidad".

Como sostiene Malizia, la legislación nacional prácticamente no se aplica en la Provincia. La excepción fue en el 2009 por la fuerte demanda de la sociedad ante el incremento de la quema de caña ${ }^{23}$. Ese año la policía detuvo a varios empleados de explotaciones cañeras que fueron encontrados en el campo mientras se producía

\footnotetext{
${ }^{21}$ Entrevista personal, 14 de agosto de 2012.

22 Entrevista personal, 18 de octubre de 2012.

${ }^{23}$ En el año 2009, el Laboratorio de Sistema de Información Territorial del INTA Famaillá detectó 1.801 focos de calor en Tucumán, lo que representó un incremento del 95\% respecto del promedio anual 2004-2008. El 45\% de esos fuegos se registró sobre caña de azúcar.
} 
la quema, ya sea controlando el fuego o apagando en los casos en que la quema fue vandálica.

Cristina Biaggi y Alejandro Valeiro (2012: 5) explican que esta situación trajo aparejado otro inconveniente: "provocó que los productores quemaran sus cañas y no permanecieran en el sitio para evitar ser sancionados. Esto promovió una 'quema no controlada', que sumada a la caña helada y seca, aumentó la superficie con fuego en esta campaña”.

En cuanto a la legislación provincial, en Tucumán existen dos disposiciones legales que regulan la prohibición de la quema de caña de azúcar. La Ley № 7459 del año 2004, que establece que se prohíbe en todo el territorio de la provincia la quema de vegetación enraizada, arraigada, aclimatada o seca para evitar la degradación de los suelos, la atmósfera, los daños a la salud de la población y el desequilibrio del ecosistema. Esta ley está reglamentada a través del Decreto $\mathrm{N}^{\circ}$ 795/3 del 2005 (modificado por Decreto № 2523/9-2008), referido específicamente al cultivo de la caña de azúcar. En el 2007 se sumó la Ley № 7873 que prohíbe a los ingenios recibir caña quemada y cosechada con máquinas integrales, reglamentada mediante el Decreto №3695/3-2008.

La Ley $N^{\circ} 7459$ se creó en el año 2004 a partir de un proyecto del Legislador Sisto Terán. La Dra. Florencia Sayago ${ }^{24}$ sostiene que, al momento de reglamentarla, el Ministerio de Desarrollo Productivo de la Provincia consultó a los organismos de ciencia y técnica como la Estación Experimental Agroindustrial Obispo Colombres (EEAOC) y el INTA, "quienes plantearon que esta ley era imposible de implementar de forma inmediata. Había que hacerlo de forma gradual, no tanto por cuestiones sociales, sino económicas. No teníamos números, pero sí había un gran porcentaje de pequeños productores que no podían adquirir las máquinas para cosechar en verde y la única forma era quemando".

Para mitigar la prohibición absoluta de esta ley, se elaboró el Decreto $N^{\circ}$ 795/3 en el 2005 (modificado por Decreto № 2523/9-2008), que hace referencia específicamente a la prohibición de la quema de caña de azúcar como método auxiliar de la cosecha con multas que van desde 500 Its. hasta 2.500 Its. de gasoil por cada infracción. Pero, sostiene que tal práctica será admitida excepcionalmente para los productores minifundistas menores de 50 hectáreas, a fin de preservar la

\footnotetext{
${ }^{24}$ La Dra. Florencia Sayago participó en la elaboración de la ley y su decreto reglamentario como abogada de la Secretaría de Medio Ambiente de la Provincia de Tucumán.
} 
sustentabilidad socioeconómica de su actividad, dentro de un plan de reducción progresiva.

Para ello, el documento legal explica que la Dirección de Fiscalización Ambiental (dependiente de la Secretaria de Medio Ambiente de la Provincia) habilitará un Registro de Productores Cañeros para que se inscriban aquellos que utilicen la quema como método de cosecha. Además, implementará un Plan de Erradicación de Quema de Caña para que los productores inscriptos en el registro puedan solicitar anualmente autorización para realizar la quema, acreditando el cumplimiento de las metas de reducción establecidas en el Plan (5\% del área cada año, en un plazo de 20 años para que la práctica esté completamente eliminada). Pero, aclara que esta prohibición progresiva excluye las seis áreas protegidas del Art. 9 del decreto que mencionamos en el capítulo anterior, donde la prohibición es absoluta.

En dicho decreto se menciona la promoción de capacitación para el personal responsable del frente de cosecha, a fin de una práctica correcta de la quema de caña de azúcar. También, la realización de acciones educativas y de difusión en todos los niveles para promover en la comunidad conductas ambientalmente correctas en relación a la quema de caña de azúcar, a cargo de la Secretaría de Educación, la Secretaría de Información Pública y el Ministerio de Desarrollo Productivo.

La implementación de este decreto con la excepción de quema controlada para los pequeños productores, la capacitación para el personal de los campos cañeros y las acciones de educación y difusión destinadas a la comunidad nunca se puso en funcionamiento. En una reunión de la Mesa de Gestión con la Comisión de Medio Ambiente de la Legislatura de Tucumán, realizada el 3 de agosto del 2012, el Ing. Alfredo Montalván, Secretario de Medio Ambiente de la Provincia, lo explicaba así: "la ley dice lo siguiente: como hay métodos auxiliares de cosecha y queremos erradicar contempla a los pequeños productores de 50 para abajo, pero dice que se deben inscribir en un registro y presentar un plan de mínima. Hemos buscado por todos los medios y nunca se han inscripto por varias razones".

Lo que sí se cumple es la aplicación de multas por el incumplimiento de las disposiciones del decreto. El abogado Facundo Moreno $^{25}$ de la Dirección de Fiscalización Ambiental sostiene que "en teoría controlamos todo el decreto y la ley.

${ }^{25}$ Entrevista personal, 14 de agosto de 2012. 
En la práctica no porque no podemos, no damos abasto. Acudimos a los casos enumerados en el Art. 9. de prohibición absoluta porque estas son las quemas con mayores repercusiones, mayores denuncias. La quema típica que se denuncia es la del borde de la ruta. El inspector si no es uno de los casos del Art. 9 no se va a meter en el medio del campo a buscar, es propiedad privada, no sabés cómo vas a pasar".

El abogado dice que a pesar de la falta de recursos humanos "nuestros inspectores salen todos los días de inspección, vuelven tapados de humo, se meten en medio de los caminos a geo-referenciar, levantan actas. Son dos camionetas y cuatro tipos, tampoco podemos solucionar el problema. Pero se levantan actas $y$, por lo menos, saco por semana 10 multas por quema de caña".

Esta ley es muy criticada, especialmente por el sector productivo, por el modo en que fue elaborada, sin consultar a todos los actores vinculados; pero también por los organismos de ciencia y técnica de la provincia, que reconocen que ante la complejidad de la problemática la legislación debería considerar una erradicación progresiva para todos los casos, donde el cambio sea gradual, ya que las tecnologías de reemplazo aún no están disponibles, tanto para la quema de la caña como la del rastrojo.

En la primera reunión de la Mesa de Gestión, realizada el 21 de mayo de 2010, el Sr. José Torres, productor de la Cooperativa Famaillá, sostenía que "desgraciadamente hicieron una ley y, como se hacen a veces las cosas así por gente inexperta, es una ley demasiado dura y drástica. No se quema. Es imposible. Todo tiene que tener un margen de flexibilidad, que creo que es lo que estamos planteando [...] La ley debe ser modificada por profesionales, agricultores que entiendan del tema".

En este sentido, si bien el decreto considera excepciones para los pequeños productores que queman la caña en el sistema de cosecha semimecanizada, no contempla la quema del rastrojo y las situaciones especiales donde los medianos y grandes productores no pueden utilizar la máquina integral para cosechar en verde. Así lo explicaba el productor Manuel Ponce en la tercera reunión de la Mesa, el 16 de junio de 2010: "hay una multiplicidad de zonas de laderas o con piedras o de lotes de pequeñas dimensiones donde la cosecha integral todavía no da la solución, donde tenemos que legislar porque al productor grande, que tiene más de 50 has, la legislación no lo ampara, avala sólo al que tiene menos de 50 hectáreas". 
Incluso, desde la misma Secretaría de Medio Ambiente sostienen la dificultad de implementar este decreto. Como plantea Florencia Sayago 26 , "la posición de que la quema de caña siempre es un delito a nosotros nos pone en un problema de que no podés permitir administrativamente lo que penalmente está prohibido. No podés decir que vaya preso, pero la administración pública no le pone multa. Es bastante difícil de sostener. La justicia penal es la mayor protección que hay porque si se considera que hay una conducta que es peligrosa para la sociedad, es medio difícil decir bueno no es tan peligrosa, la vamos a permitir nosotros".

En el año 2007, a medida que se intentaba poner en funcionamiento esta ley y su decreto reglamentario, se creó la Ley № 7873 que prohíbe a todos los ingenios recibir caña de azúcar quemada y cosechada con máquinas integrales. En el 2008 fue reglamentada mediante el Decreto $N^{\circ} 3695 / 3$. Pero, el control de esta ley tampoco se cumple de manera eficiente, ya que no se cuenta con un mecanismo de control permanente en cada uno de los 15 ingenios de la Provincia.

En el 2009, una comisión de la Legislatura realizó el digesto jurídico de la Provincia $^{27}$, un trabajo de saneamiento de toda la legislación provincial mediante el cual las Leyes № 7459 y № 7873 fueron incluidas dentro del Art. 38 de la Ley № 6253 sobre "Normas Generales y Metodología de Aplicación para la Defensa, Conservación y Mejoramiento del Ambiente" como primer y segundo párrafo respectivamente. De este modo, estas dos leyes como tales quedaron derogadas 0 caducas, pero su texto y decretos reglamentarios están vigentes en la Ley № 6253.

\section{Alternativas tecnológicas para la erradicación de la quema}

Una de las cuestiones centrales que actualmente impide erradicar la quema como herramienta de producción, y que es competencia de las instituciones de ciencia y técnica de Tucumán, es la falta de tecnologías disponibles que permitan evitar la quema de caña y del rastrojo o maloja.

En este sentido, instituciones como el INTA y la Estación Experimental Agroindustrial Obispo Colombres (EEAOC) vienen trabajando en el desarrollo de alternativas como la cosechadora de caña en verde adaptada a pequeñas

\footnotetext{
${ }^{26}$ Entrevista personal, 14 de agosto de 2012.

${ }^{27}$ Se realizó un trabajo de saneamiento de toda la legislación provincial mediante el cual muchas leyes quedaron caducas, dejando en vigencia unas 600 , que actualmente son consideradas el derecho vigente de la Provincia.
} 
superficies y el enrollado de la maloja para ser utilizada en la producción de energía, carbón, ladrillos o como cobertura de otros cultivos. Pero, estas tecnologías aún no fueron transferidas al sector, ya que se encuentran en etapa experimental o bien se desarrollan a baja escala para resolver la problemática.

\section{Propuestas de reemplazo para la quema de caña}

Los pequeños productores utilizan el sistema de cosecha semi-mecánico, donde se quema la caña, porque las máquinas integrales son muy costosas e inadecuadas para realizar la cosecha en los predios de pequeñas superficies. Por otra parte, algunos productores medianos y grandes también lo utilizan en algunos lotes que tienen dificultades para el ingreso y circulación de la máquina integral por problemas de superficie.

Ante esta situación, en el año 2007, diferentes unidades del INTA comenzaron a trabajar en el diseño de una máquina como las integrales pero adaptada a la agricultura familiar. En el proceso de desarrollo participan la EEA Reconquista, el Instituto para la Pequeña Agricultura Familiar del NOA, el Centro Regional Tucumán - Santiago del Estero, la EEA Famaillá, el Programa Nacional de Cultivos Industriales y el Área Estratégica de Agroindustrias. También hacen sus aportes productores, técnicos privados, organizaciones cañeras e instituciones del área.

En el año 2009 se presentó el primer "Prototipo experimental de cosechadora de caña de azúcar en verde para pequeños productores", un equipo que va acoplado al tractor y realiza el despunte, corte basal y pelado de la caña para enviarla a un carro de transporte que tiene un sistema con posibilidad de vuelco.

Después de varios ajustes en el diseño, durante el 2011 se entregó la primera cosechadora a la Cooperativa La Tuna de Tucumán para que los mismos productores junto a los técnicos evalúen el funcionamiento del equipo en sus predios. Ésta fue construida por el Consorcio Metalmecánico de Tucumán (integrado por los Talleres González \& Fortini, Mecánica y Mecanizados Mesón y Metalúrgica Col-Ixon Metal S.A.) con el financiamiento del Gobierno de la Provincia. Desde el 2012 se están construyendo dos nuevos equipos para ser entregados a otras cooperativas de la Provincia con la misma finalidad. 
Si bien esta máquina aún se encuentra en etapa experimental, los productores pequeños la ven como una gran oportunidad para acceder a la tecnología y dejar de quemar. Felipe Romero ${ }^{28}$, presidente de la Cooperativa La Tuna de Simoca, sostiene que "la máquina va a ser una gran cosa para nosotros porque hasta ahora siempre hemos hecho todo manual y estos últimos años ha sido un retroceso porque ya no hay gente para hacer este tipo de trabajo. Y si mañana se hace el no quemado de caña estaríamos quedando en el aire, pero con esto, gracias a Dios y a la gente que de una u otra forma nos ha colaborado, creo que vamos a salir de este aprieto".

\section{Propuestas de valorización de la maloja}

"La cantidad potencial de residuos agrícolas de cosecha (RAC) de caña de azúcar disponible en Tucumán es de 3.600 .000 toneladas, de las cuales se podría recolectar y utilizar el $50 \%$ para no eliminar completamente la cobertura del suelo" (Fernández de Ullivarri, Vallejo y Valeiro, 2011: 71).

La posibilidad de darle valor a estos residuos agrícolas de cosecha que quedan en el campo después de la recolección mecanizada y utilizarlos para otras producciones ayudaría a disminuir las quemas.

Las instituciones de investigación están evaluando diferentes alternativas. Entre ellas se encuentra la instalación de plantas de generación de energía domiciliaria e industrial utilizando como insumo el RAC en el país. Un estudio realizado por el INTA sobre distintos escenarios de aprovechamiento y transformación del RAC sostiene que "Tucumán cuenta con un potencial de generación de energía, a partir del aprovechamiento del residuo de cosecha de caña de azúcar, que permitiría la instalación de al menos dos plantas de generación en su territorio sin que éstas compitan por el uso del recurso" (Anschau, Sopena, Benedetti y Valeiro, 2011: 47).

Sin embargo, se plantean algunas dificultades para la puesta en funcionamiento de estas plantas. Durante el 2011, la empresa Pluspetrol Energy S.A. realizó un proyecto para la instalación de una planta que utilice la maloja como combustible para la generación de energía eléctrica en la Central El Bracho de la provincia de Tucumán. Pero, sostiene que no puede ponerlo en funcionamiento porque la política energética, dependiente del Estado Nacional, no le ofrece las

${ }^{28}$ Entrevista personal, 27 de octubre de 2011. 
garantías necesarias para realizar la inversión. Alejandro Vigo ${ }^{29}$, Power Generation Manager de la empresa, lo explica así: "el estudio que hemos podido hacer en estos 18 meses, lo hemos hecho con nuestros propios recursos y hemos logrado llegar a la conclusión de que el proyecto es factible y se puede hacer. Por qué no lo hacemos, por la política. Para hacerlo necesitamos que cambie la política porque no hay ninguna otra barrera [...] Para esto necesitamos apalancamiento político, que se nos reconozca un precio adecuado, se nos pague, se nos respete y se nos dé seguridad jurídica".

También, desde la EEAOC se analizó específicamente el acondicionamiento y transporte del RAC en verde para su posterior combustión en las calderas de los ingenios azucareros a fin de evitar el costoso gasto del combustible adicional (fuel-oil o gas natural). El procedimiento consiste en acondicionar el rollo de maloja mediante un sistema de picado y desmenuzado, transportarlo mediante rastras bagaceras hacia la zona de alimentación de las calderas e incorporarlo para su combustión en el hogar.

En el informe, la Estación Experimental Agroindustrial Obispo Colombres (2009: 13-14) destaca que "la caldera quemando originalmente bagazo, no sufre alteración en su comportamiento energético ante la incorporación del RAC al hogar, destacándose entonces la gran compatibilidad que presentan ambos combustibles [...] Por día de zafra se producen 1.800 toneladas de RAC al 10\% de humedad y $11 \%$ de cenizas, que equivale energéticamente a $426.600 \mathrm{Nm} 3$ de gas, esto representa el $45,61 \%$ del gas consumido por día".

Otra de las alternativas que evaluó el INTA es la utilización del RAC como fuente energética para la producción de ladrillos. El proceso es el siguiente: diez días después de la cosecha mecanizada de caña de azúcar, se recolectan los residuos con una rotoenfardadora de forrajes. Posteriormente, se alimenta manualmente un horno de 3.000 ladrillos (construido especialmente para la experiencia) durante un proceso continuo de 112 hs., más un período de enfriado.

Enrique Fernández de Ullivarri y Sergio Pérez (2008) explican que "los resultados obtenidos fueron una terminación acabada (coloración óptima) en el 30\% de los ladrillos, un color pálido en el $65 \%$ y sólo un 5\% de lo producido se manchó por cenizas del RAC quemado. Todos eran aptos para comercializar, por lo que

${ }^{29}$ Entrevista personal, 13 de septiembre de 2012. 
quedó demostrado que es posible sustituir o complementar el uso de leña por el de RAC en la producción de ladrillos".

EI INTA también estudió la elaboración de briquetas de carbón con residuos agrícolas de cosecha. El proceso de producción se inicia en el campo con la recolección de la materia prima (RAC) por medio de rastrillos $u$ horquillas. Luego, se cargan los tachos, compactando ligeramente el material y se tapa. Dentro del horno, se arma una cama de $20 \mathrm{~cm}$. de residuos en la parte inferior, se introducen los tachos, se rellenan los intersticios con RAC, se pone otra cama de 20 $\mathrm{cm}$. de residuos sobre los tachos y se coloca la tapa. Finalmente, se enciende el horno por la parte inferior para quemar el material a través de una combustión incompleta llamada "pirolisis" que dura dos horas; luego se deja enfriar y se obtiene la carbonilla.

Para realizar el armado de las briquetas se debe formar una pasta, mezclando la carbonilla con harina de trigo o mandioca, almidón de maíz o miel de caña como ligante. Luego, se amasa hasta homogeneizar la pasta y se compacta por medio de una máquina briqueteadora. Debido a que las briquetas salen húmedas, se llevan a un secadero que puede ser de tipo túnel con plástico o simplemente bajo un techo a temperatura ambiente.

De acuerdo a la cantidad potencial de RAC disponible en Tucumán, Enrique Fernández de Ullivarri, Juan Vallejo y Alejandro Valeiro (2011: 71-72) sostienen que "considerando un rendimiento en el proceso de carbonización del 15\%, sería posible producir 270.000 t de briquetas de carbón [...] El principal uso que se les puede dar a las briquetas es en el hogar para asar carne y en su calefacción. Si bien con esta propuesta se sigue quemando RAC, de esta manera la quema se lleva a cabo en forma controlada, generando un producto que puede ser utilizado para reemplazar el carbón de leña cuyo costo se está incrementando marcadamente dada la paulatina limitación de los desmontes".

Además de estas propuestas, se llevaron adelante experiencias en las que se utiliza la maloja como acolchado (mulching) para cultivos de frutas y hortalizas, a fin de evitar el uso de la cobertura plástica, ya que su durabilidad se limita a uno o dos años generando residuos cuyo reciclaje es dificultoso. Los estudios del INTA demuestran que el acolchado vegetal de maloja de caña de azúcar amortigua las temperaturas extremas del ambiente e incorpora materia orgánica al suelo. 
Sin embargo, todas estas alternativas para darle uso a la maloja aún se encuentran en etapa experimental sin haberse logrado una adopción por parte de los productores. Como explican Cristina Biaggi y Alejandro Valeiro (2012: 4):

A pesar de estar disponible en grandes cantidades, el uso de la maloja resulta todavía costoso tanto por sus bajos contenidos calóricos como por los grandes volúmenes que hay que manipular y almacenar para generar electricidad, calor $u$ otras formas de energía. Esto hasta ahora ha impedido su utilización masiva, y se están buscando maneras de hacer rentable su uso. En los últimos años tanto el INTA como empresas de servicio, industrias e instituciones de investigación vienen llevando adelante iniciativas para dar solución técnica y económica al principal "cuello de botella" de esta propuesta: el costo del sistema logístico para recoger y transportar la maloja hacia su uso final. En esta perspectiva, se han desarrollado rastrillos, enfardadoras de distinto tipo y enrolladoras de maloja. 
En este capítulo nos proponemos realizar un pre-diagnóstico, es decir, una mirada inicial sobre la Mesa de Gestión Ambiental de Cruz Alta para lograr una descripción general de la misma y evaluar la viabilidad y factibilidad del diagnóstico comunicacional que nos planteamos en esta tesis.

La Mesa se conformó impulsada por actores sociales que estuvieron y están directamente involucrados en la problemática de la quema de caña de azúcar. Los mismos lograron, desde el año 2010, constituir organizacionalmente sus relaciones, inquietudes, perspectivas, estudios y diálogos, lo cual quedó asentado en sus discursos, productos comunicacionales, acuerdos e intervenciones realizadas.

Para conocer este proceso a partir del saber construido en la propia organización utilizaremos documentos elaborados por el INTA a nivel regional y nacional y bibliografía actualizada sobre la temática específica. Además, a través de la metodología de análisis de discurso abordaremos las actas y los audios de las reuniones de la Mesa. Todo dirigido a construir una realidad de los actores con su visión e intereses sobre la problemática.

En este sentido, nos basaremos en lo que expresa Eliseo Verón (1998: 125) sobre los discursos: "toda producción de sentido es necesariamente social: no puede describir ni explicar satisfactoriamente un proceso significante sin explicar sus condiciones sociales productivas. Todo fenómeno social es, en una de sus dimensiones constitutivas, un proceso de producción de sentido, cualquiera que fuere el nivel de análisis (más o menos micro o macro sociológico)". Las herramientas metodológicas son parte de la construcción espaciotemporal de sentido necesaria para realizar el recorrido de investigación y dar cuenta de algunas huellas en los discursos sociales que son clave para entender "los modos de organización institucional, la naturaleza y el juego de los conflictos" (Verón, 1998: 126).

Por su lado, Michel Foucault (1969, citado por Murillo, 2008: 7) entiende discurso no como una "mera relación lingüística sino como un entramado de enunciados que circulan entre los cuerpos en prácticas, que son siempre relaciones de poder, constituyendo sentido. La constitución del sentido, o de los sentidos, brota no sólo de aquello que se dice, sino de quién, a quién, dónde, cómo, desde qué posición". 
También utilizaremos la técnica de la entrevista semi-estructurada para completar el conocimiento de los actores. "Este tipo de entrevistas son muy útiles para obtener la información que proporcionan los entrevistados cercanos a una situación problemática sobre la que se pretende realizar posteriormente alguna forma de intervención social. Esto permite, por una parte, captar experiencias vividas $y$, por otra, facilita una cierta confrontación entre lo que se dice y la conducta real, aportando mayor veracidad y fiabilidad a la información obtenida" (Ander-Egg, 2000: 72).

Las entrevistas se basan "en un guion que el entrevistador utilizará con flexibilidad, tanto en el orden en que han de ser formuladas las preguntas, como en el modo de hacerlo. En cuanto al orden, el entrevistador utilizará la secuencia que estime oportuna; y, en cuanto al modo de formularlas, en cada caso puede adaptarlas utilizando un lenguaje familiar con cada entrevistado" (Ander-Egg, 2000: 73).

\section{EI INTA en el territorio}

En el mes de mayo del 2010, fue la Estación Experimental Agropecuaria Famaillá del INTA la que convocó a los demás sectores para debatir y reflexionar respecto de soluciones para la problemática de la quema de caña, dando origen a la Mesa de Gestión Ambiental de Cruz Alta. Por esto, resulta necesario conocer el funcionamiento de dicha institución pública nacional en la provincia de Tucumán para comprender la legitimidad de su trabajo en el territorio.

El Instituto Nacional de Tecnología Agropecuaria es un organismo estatal descentralizado, con autarquía operativa y financiera, dependiente del Ministerio de Agricultura, Ganadería y Pesca de la Nación. Fue creado el 4 de diciembre de 1956, mediante el Decreto Ley 21.680/56, con la finalidad de "impulsar, vigorizar y coordinar el desarrollo de la investigación y extensión agropecuaria y acelerar, con los beneficios de estas funciones fundamentales, la tecnificación y el mejoramiento de la empresa agraria y de la vida rural".

Desde su creación, desarrolla acciones de investigación e innovación tecnológica en las cadenas de valor, regiones y territorios para mejorar la competitividad y el desarrollo rural sustentable del país. Por ello, sus esfuerzos se orientan a la innovación como motor del desarrollo e integra capacidades para 
fomentar la cooperación interinstitucional, generar conocimientos y tecnologías y ponerlos al servicio del sector a través de sus sistemas de extensión, información y comunicación.

La Institución tiene presencia en las cinco ecorregiones de la Argentina (Noroeste, Noreste, Cuyo, Pampeana y Patagonia), a través de una estructura que comprende: una sede central, 15 Centros Regionales (CR), 5 Centros de Investigación (CI), 50 Estaciones Experimentales Agropecuarias (EEA), 16 Institutos y más de 300 Unidades de Extensión (UE). En el ámbito de la Dirección Nacional funciona una estructura programática integrada por Programas Nacionales y Áreas Estratégicas con incumbencia en los niveles nacional y regional.

Dentro de esa estructura, en todo el país sus agentes trabajan en cuatro componentes estratégicos: investigación y desarrollo tecnológico, extensión y desarrollo rural, relaciones institucionales y vinculación tecnológica.

EI INTA, a través de este esquema de funcionamiento, ha transitado los diferentes escenarios del país acompañando las transformaciones significativas del sector agropecuario. Dichas transformaciones se reflejaron en el rediseño y readecuación de su organización y estrategias para hacer frente a las nuevas necesidades y demandas del sector productivo a pequeña y gran escala.

Así, en la actualidad, las estrategias y acciones en el territorio de los CR, las EEA y las UE del INTA en toda la Argentina siguen los lineamientos marcados en el Plan Estratégico Institucional 2005-2015 (PEI) ${ }^{30}$, donde se expone una visión de largo plazo para responder a las demandas de todas las regiones del país.

El objetivo de desarrollo planteado en el PEI (INTA: 2004: 32) es el de "fortalecer el desarrollo nacional, regional y territorial contribuyendo a la sostenibilidad social, económica y ambiental del Sistema Agropecuario, Agroalimentario y Agroindustrial (SA). Se plantea conjugar integralmente los aportes a la competitividad, sostenibilidad ambiental y equidad social del SA en sus tres ámbitos de intervención: cadenas de valor, sistemas productivos/agro-ecosistemas y territorios, articulándolos en los espacios nacional, regional y local desde una perspectiva de desarrollo".

\footnotetext{
${ }^{30}$ EI PEl fue publicado en diciembre del 2004. En su elaboración participó todo el personal de INTA del País y diferentes representantes del Sector Agropecuario, Agroalimentario y Agroindustrial y del Sistema Científico-Tecnológico de Argentina.
} 
Además, en el PEl se definen tres objetivos generales que deben estar presentes en todas las líneas de acción que llevan adelante los agentes de la Institución junto a los diferentes actores con los que articulan en el territorio: competitividad, salud ambiental y equidad social.

Acercándonos más al foco de nuestra tesis, el funcionamiento del INTA en Tucumán, veamos cómo se estructura la organización y funcionamiento de la Estación Experimental Agropecuaria Famaillá dentro del Centro Regional TucumánSantiago del Estero (CRTUSGO).

El CR, cuya sede operativa se encuentra en Tucumán, abarca ambas provincias de la Región del NOA, trabajando con una gran diversidad de agroecosistemas que dan sustento a una alta heterogeneidad de actividades y sistemas de producción, tradicionalmente insertas en lo que se denomina "economías regionales".

Su estructura se compone de tres EEAs: la de Famaillá en Tucumán y las de Santiago del Estero y Este de Santiago del Estero en dicha provincia; 13 AER; 9 Unidades de Extensión y Experimentación Adaptativa (UEyEA); 3 Oficinas de Información Técnica (OIT) y 2 Delegaciones de Extensión Rural (DER) para atender las necesidades de los productores del sector.

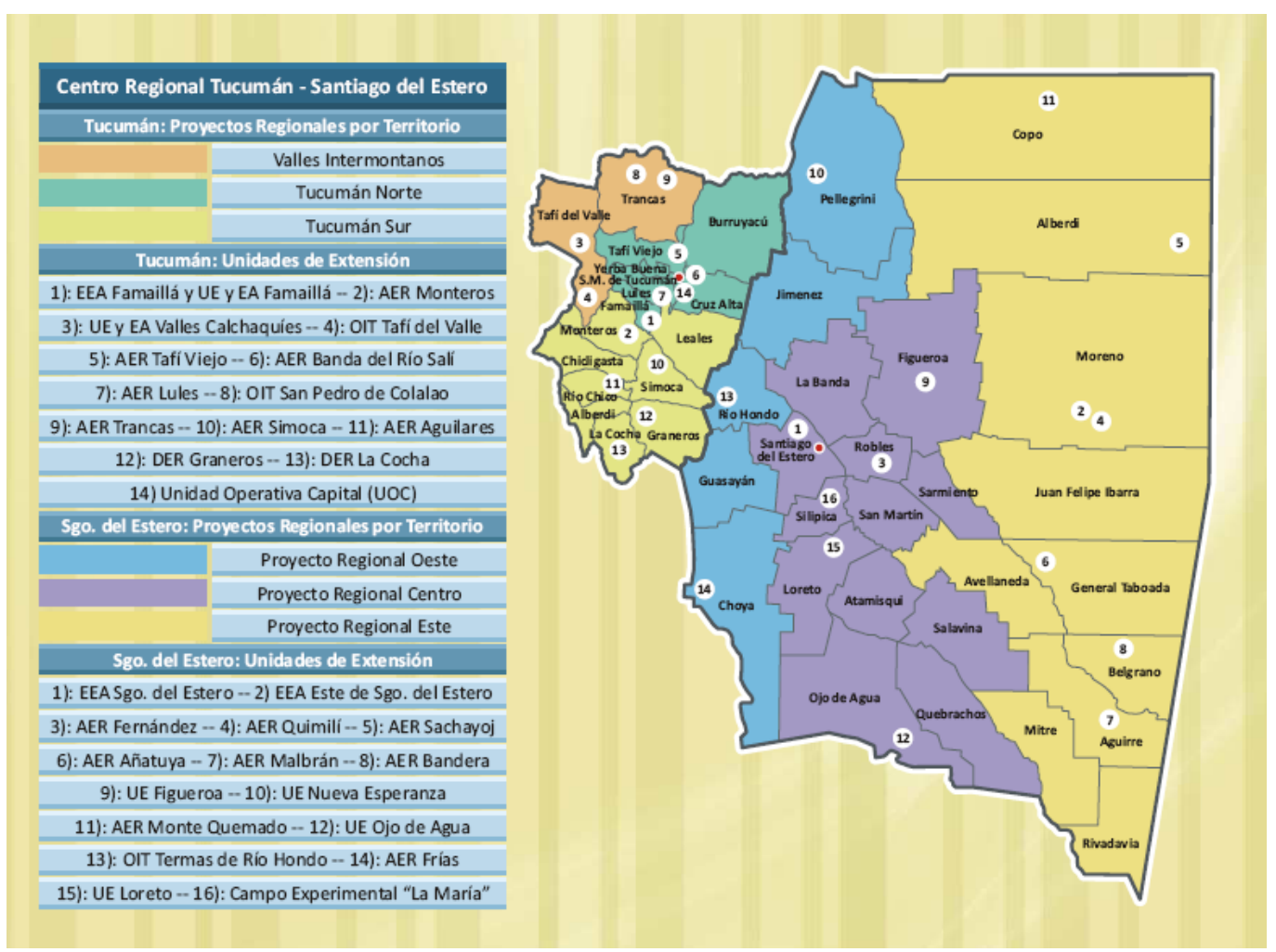


Además, cuenta con el Consejo del Centro Regional Tucumán-Santiago del Estero, conformado por representantes de distintas asociaciones de productores, gobiernos provinciales, comunidad científica y universidades de ambas provincias. Es la máxima autoridad política en su ámbito y su responsabilidad es la de establecer las políticas, estrategias y la asignación de recursos de su Centro, asegurando la correspondencia entre las actividades de la Institución y la problemática en sus ámbitos de intervención en el territorio.

EI CR mantiene una amplia red de relaciones institucionales para trabajar en el territorio con los gobiernos provinciales y municipales, universidades, establecimientos educativos, empresas privadas, cooperativas, mutuales, centros comerciales e industriales, asociaciones de la sociedad civil de Tucumán, el NOA, Argentina y otros países, especialmente latinoamericanos.

Las acciones de las EEAs y las Unidades de Extensión del CRTUSGO se desarrollan en el marco de una estrategia de proyectos regionales englobados en el Plan Tecnológico Regional 2009-2011 (PTR). Éste fue elaborado a partir de los problemas y oportunidades captados y de líneas de acción propuestas en los talleres territoriales realizados entre el 2005 y 2008 con la participación de todos los agentes de la Institución y los actores con los que se vinculaban en el territorio. "En esta estrategia, el Centro adoptó un enfoque de desarrollo territorial con el objetivo de articular y comprometer voluntades en pos de un objetivo común a partir de identificar y comprometer a los actores y recursos locales en proyectos y acciones en cada territorio" (INTA, 2008: 4).

Entre las problemáticas planteadas en el territorio, el documento expresa: el monocultivo, la deforestación, desertificación, degradación físico-química de los suelos, pérdida de biodiversidad, bajos niveles de adopción de las tecnologías, migración, falta de información útil y relevante para la intervención en sistemas productivos con enfoque de ecorregión; débil poder de negociación de las organizaciones de pequeños productores frente a otros actores; prevalencia de un modelo de desarrollo no sustentable ni equitativo; falta de capacitación de los recursos humanos; baja participación del INTA en espacios de concertación local.

Específicamente en relación al problema abordado por la Mesa de Gestión, el PTR habla de una profundización de problemas ambientales que representan importancia para la región. Entre ellos menciona la contaminación de suelos, aguas y aire por agroquímicos y prácticas de manejo como la quema de cañaverales; la 
erosión hídrica y eólica por desmontes; las prácticas de manejo y riego ineficientes, profundizados por la intensificación de la producción y la expansión a ecosistemas frágiles.

A partir de estas problemáticas y de las oportunidades identificadas, el Plan Tecnológico Regional propone diferentes líneas de acción englobadas en 6 proyectos regionales por territorio: PR Valles Intermontanos, PR Tucumán Norte y PR Tucumán Sur para dicha provincia; y PR Oeste, PR Centro y PR Este para Santiago del Estero.

De este modo se puede identificar a la problemática ambiental $y$, específicamente, a la quema de cañaverales como una fuerte demanda del territorio que debe ser atendida por el INTA en Tucumán, ya que concentra el $62 \%$ de la producción de azúcar del país.

Veamos, entonces, cómo trabaja el INTA en la provincia. La institución inició sus actividades el 1 de abril de 1958 con el desarrollo de tecnologías relacionadas a la producción de caña de azúcar. Pero, recién en el año 1962 se instaló la EEA Famaillá como funciona en la actualidad, en un predio de 358 ha. ubicado en la Ruta Provincial № 301, Km. 32, Padilla, Famaillá, Tucumán. Esto da cuenta de la importancia de este cultivo para la institución y de la trayectoria de trabajo que tiene con los productores del sector.

La estructura de la Experimental cuenta con la Dirección y las áreas de investigación e innovación, extensión y desarrollo rural, administración y las transversales como economía, comunicaciones, informática y biblioteca. Cada una de ellas cuenta con un coordinador y grupos de trabajo con un jefe o responsable.

En investigación e innovación, el INTA Famaillá orienta sus líneas de acción a la generación y transferencia de conocimientos y tecnologías en caña de azúcar, frutihorticultura/citrus, frutas finas, apicultura, recursos naturales, forestales, floricultura, gestión ambiental, agrometeorología, agroindustria y calidad agroalimentaria. También, cuenta con cuatro laboratorios especializados: Suelos, Sistemas de Información Geográfica (SIG-GPS), Fitopatología (Sección Caña de azúcar) y Agroindustria, situados en la EEA Famaillá.

En relación a la intervención en el territorio desarrolla un fuerte trabajo con pequeños, medianos y grandes productores, por medio del Programa Federal de Apoyo al Desarrollo Rural Sustentable (PROFEDER). Se destaca el trabajo que realiza en temas de enfoque social como la seguridad alimentaria mediante el 
Programa Pro Huerta ${ }^{31}$ y las actividades vinculadas a la evaluación de pérdidas de cosecha y la agricultura de precisión en granos y caña de azúcar.

Para conocer las demandas del sector y poner las nuevas tecnologías al servicio de los productores, el INTA Famaillá operacionaliza los programas del PROFEDER a través de las UE ubicadas en los distintos puntos de la Provincia de Tucumán: 7 AERs (Trancas, Tafí Viejo, Banda del Río Salí, Lules, Monteros, Simoca y Aguilares), 2 UEyEAs (Amaicha del Valle y Famaillá), 2 DERs (Graneros y La Cocha), 2 OIT (Tafí del Valle y San Pedro De Colalao) y 1 UOC (San Miguel de Tucumán).

Toda la labor de investigación y trabajo en terreno junto a los productores de la región se desarrolla a través de grupos de trabajo multidisciplinarios (intervienen profesionales de las ciencias agronómica, química, forestal, económica, comunicacional) y en acuerdos de vinculación institucional y tecnológica con el gobierno provincial, los gobiernos municipales, las universidades, los institutos de ciencia y técnica, organizaciones de la sociedad civil, asociaciones de productores y empresas privadas.

Entre ellos se destaca el Ministerio de Desarrollo Productivo y unidades dependientes del Gobierno de Tucumán; las Municipalidades de Trancas, Lules, Famaillá y Monteros; la Facultad de Agronomía y Zootecnia y la Facultad de Bioquímica, Química y Farmacia de la Universidad Nacional de Tucumán; la Universidad de San Pablo-Tucumán; la Estación Experimental Agroindustrial Obispo Colombres; el Consejo Nacional de Investigaciones Científicas y Técnicas (CONICET) y algunos de sus centros dependientes como el Centro de Referencia de Lacto Bacilos (Cerela), la Planta Piloto de Procesos Industriales Microbiológicos (Proimi) y el Instituto Superior de Investigaciones Biológicas (Insibio); la Fundación Miguel Lillo y su Centro de Investigaciones sobre el Control de Poblaciones de Organismos Nocivos (CIRPON); los CR NOA Norte y NOA Sur del Servicio Nacional de Sanidad y Calidad Agroalimentaria (SENASA); la Delegación Regional NOA del Instituto Nacional de Semillas (Inase); la Unidad Operativa NOA Tucumán del Instituto Nacional de Tecnología Industrial (INTI); el Programa de Servicios Agrícolas Provinciales (PROSAP); el Programa de Desarrollo Rural del Noroeste Argentino (PRODERNOA); la Sociedad Rural de Tucumán; el Colegio de Ingenieros

\footnotetext{
${ }^{31}$ El Programa Pro Huerta forma parte de un convenio entre el INTA y el Ministerio de Desarrollo Social de la Nación.
} 
Agrónomos y Zootecnistas de Tucumán; la Fundación del Tucumán. También tiene una extensa red de relaciones con otras Unidades del INTA de la región y el país.

El área de comunicaciones del INTA Famaillá, en la cual trabajo desde el año 2007, funciona como un servicio de apoyo y asistencia al resto de los grupos de trabajo desde un enfoque operativo instrumental basado en la trasmisión de información tanto interna como externamente. Para ello se usan diferentes canales como el correo electrónico y las carteleras en el caso de la difusión interna y los medios de comunicación y materiales gráficos (cartillas, folletos, libros) y audiovisuales (videos) para la difusión externa.

En este sentido, se reconoce a la comunicación y a los comunicadores como un medio o canal, cuyo rol es la traducción de los mensajes para adecuarlos a las diferentes audiencias, logrando transmitir lo que se desea. De este modo, el comunicador/a no forma parte del proceso de producción de los materiales, sino que es citado en la etapa final para adecuar los mensajes a los públicos a los que van dirigidos.

Por otra parte, se relaciona el trabajo de la comunicación con la organización de eventos (seminarios, jornadas, días de campo) y la cobertura periodística de los mismos. También se reconoce al comunicador como el agente que debe manejar las tecnologías informáticas.

Desde esta estructura de funcionamiento, la EEA Famaillá lleva adelante las líneas de acción definidas en los tres proyectos regionales elaborados para la Provincia de Tucumán.

Por ello, dentro del Proyecto Regional Tucumán Norte, el INTA Famaillá en un trabajo articulado con la AER Banda del Río Salí decidió convocar a los diferentes actores locales vinculados a la problemática de la quema para debatir y pensar en posibles transformaciones. Así se inició la Mesa de Gestión Ambiental de Cruz Alta, una organización que lleva más de tres años de funcionamiento en el territorio.

Podríamos decir que la posición del INTA Famaillá como el actor convocante de la Mesa y el que encabeza las acciones de la organización en el territorio tiene que ver con que en Tucumán "los actores sociales reconocen en el INTA un rol de liderazgo como creador, formador y gestor de redes socio-productivas" (INTA, 2008: $6)$. 
Con la participación en la Mesa, el área de comunicaciones de la EEA Famaillá inició su primera experiencia ligada al trabajo en terreno junto a los actores con los que se vincula la institución. Lo que el INTA llama comunicación para el desarrollo. Como plantea Juan Díaz Bordenave (2007: 15) en cuanto a la función de la comunicación en el desarrollo:

Estos dos subsistemas de un sistema mayor, consideran el desarrollo, el progreso agrícola, como un proceso de resolver problemas. Esto explica el abordaje sistémico, por el cual la responsabilidad comienza ya en la comunidad local, ella es la que tiene los problemas, pero para poder resolverlos es necesario que la gente se comunique entre sí, entonces es ahí donde comienza el trabajo del comunicador para el desarrollo, promoviendo el diálogo intracomunitario, el diálogo horizontal, no para hacer llegar los mensajes del gobierno. Es conseguir que la gente detecte, investigue, diagnostique su problema, lo articule, porque en general la gente no consigue resolver por sí sola sus problemas, cada día menos.

De este modo, con el proceso de diagnóstico comunicacional desarrollado junto a los actores de la Mesa en el marco de esta tesis, se comenzó a vislumbrar en el área un trabajo relacionado a la comunicación entendida como proceso de construcción de sentidos, vinculada a las prácticas sociales y las organizaciones. Como afirma Claudia Villamayor, hablamos de "prácticas sociales atravesadas por experiencias de comunicación. Prácticas sociales factibles de ser reconocidas como espacios de interacción entre sujetos, en los que se verifican procesos de producción de sentido, de creación y recreación de significados, generando relaciones en las que esos mismos sujetos se constituyen individual y colectivamente" (Villamayor, 2002: 5).

\section{Conformación de la Mesa de Gestión Ambiental de Cruz Alta}

Decíamos que la sede del INTA en Tucumán fue la institución que convocó a los demás actores para conformar la Mesa de Gestión Ambiental de Cruz Alta. Veamos, entonces, en qué condiciones se gestó esta organización en el territorio. 
Si bien la quema de caña y maloja en Tucumán existe hace muchos años, "el 2009 alcanzó el récord de "Focos de Calor" (FC). El Laboratorio de Sistema de Información Territorial del INTA Famaillá registró un total de 1.801 fuegos sobre diferentes coberturas en la Provincia, lo que representó un incremento del 95\% respecto del promedio anual de la serie 2004-2008 (924 FC). El 45\% de esos focos fueron sobre suelo ocupado con caña de azúcar" (Benedetti y Valeiro, 2011: 65).

Los datos obtenidos permitieron detectar 9 "áreas calientes" (con una superficie de $10 \mathrm{Km}^{2}$ cada una), donde se llegó a registrar hasta un máximo de 52 focos de calor en el año para cada una. Cruz Alta fue el departamento que concentró tres de esas áreas calientes, coincidiendo con que es el que tiene la mayor superficie con caña en Tucumán y en zonas muy cercanas a poblaciones, con los consecuentes riegos para la salud y la infraestructura. Las seis áreas restantes se ubicaron en Lules, Leales, Famaillá, Monteros, Río Chico y Simoca.

Esto se debió, por un lado, a las particulares condiciones meteorológicas de ese invierno, uno de los más fríos y secos de la serie histórica ${ }^{32}$. En el 2009 se produjo un gran número de heladas con una fuerte intensidad agronómica, generando un importante volumen de vegetación seca, especialmente en caña de azúcar, material altamente combustible.

Por otra parte, el endurecimiento del gobierno provincial basado en el Art. 186 del Código Penal llevó a que se detuviera a cualquier persona que se encontrara en un campo que estaba prendiéndose fuego, lo que provocó una práctica de quema descontrolada. Los productores o empleados iniciaban el fuego y no se quedaban en el sitio a controlarlo para evitar ser sancionados; tampoco acudían a apagar un fuego iniciado por terceros en sus campos.

Un caso emblemático que aumentó la presión de la sociedad civil sobre el sector cañero y las autoridades gubernamentales fue el incendio registrado el 28 de agosto de 2009 en la localidad de Los Ralos. El fuego se había iniciado en un campo de la localidad de Alabama y, alimentado por el intenso viento que corría, avanzó a lo largo de 10 kilómetros pasando por varias fincas. El incendio llegó a viviendas precarias que se encontraban ubicadas a pocos metros de una finca, por lo que las personas debieron ser evacuadas y trasladas al hospital con síntomas de intoxicación por humo. Algunas familias pudieron salvar parte de sus pertenencias,

\footnotetext{
${ }^{32}$ Según datos de la Sección de Agrometereología del INTA Famaillá, el promedio histórico del mes de julio es de cuatro y seis heladas meteorológicas y en julio de 2009 ocurrieron ocho. Las heladas agronómicas pasaron de un promedio de 10 a 28 en ese mismo mes.
} 
pero siete de ellas perdieron todo. Además, el fuego produjo daños en las instalaciones eléctricas y dejó a parte del pueblo sin luz y agua por varios días (Galindez, 2009).

Hasta ese momento, si bien las instituciones de ciencia y técnica, las universidades y el gobierno provincial venían trabajando en el tema con la búsqueda de alternativas tecnológicas en etapa experimental y mensajes publicitarios para evitar la quema, no se ejecutaron líneas de acción concretas para eliminarla. Incluso, como explicamos en el capítulo anterior, las acciones para la erradicación de la quema contempladas en la legislación provincial (Art. 38 de la Ley № 6253) no se llevaron adelante.

Frente a este escenario, técnicos del Programa Nacional de Cultivos Industriales y el Laboratorio de Sistema de Información Territorial del INTA Famaillá articularon con la Agencia de Extensión Rural Banda del Río Salí (cuya zona de influencia es el Este de la Provincia) para trabajar en el departamento Cruz Alta. De este modo, convocaron a los diversos actores vinculados con la quema para analizar la problemática y pensar la transformación.

Así, en el mes de mayo de 2010, comenzaron a reunirse investigadores y extensionistas del INTA; autoridades de las pequeñas localidades del departamento; representantes de las áreas de producción, medio ambiente, seguridad ciudadana, salud y educación del gobierno provincial; comisarios; bomberos voluntarios; organizaciones gremiales, cooperativas, grandes empresas y productores independientes del sector cañero de Cruz Alta.

En la primera reunión, el 21 de mayo de 2010, el Ing. Agr. Alejandro Valeiro del INTA exponía la opinión sobre la quema desde la visión de la Institución: "Lo que nos preocupa a nosotros como INTA es el efecto que tiene la quema de caña o de otros cultivos sobre la salud porque todos vivimos acá, así que sabemos que es un problema que tenemos todos. Segundo nos preocupa que creemos sinceramente que la producción de caña en el futuro está amenazada si esto sigue así, realmente cada vez la cosa es más complicada, la sociedad se está como poniendo en contra de la producción de caña y eso no creemos que sea bueno para el futuro. Muchos de los tucumanos vivimos de la caña y el azúcar y, por lo tanto, hay un proyecto de futuro ahí que esto lo está amenazando. Es hora de que empecemos a hacer algo entre todos". 
En cuanto al interés sobre la convocatoria, Valeiro explicaba que "la idea de esta reunión es sentarnos entre todos los actores de la zona para ver si podemos empezar algo en conjunto. Nosotros sabemos que es un tema muy complejo porque no hay un único culpable, la verdad es que tenemos que cambiar el comportamiento entre todos. La única solución es que nos sentemos en una mesa todos los que estamos, los representantes de las instituciones y la sociedad, para reducir lo más posible el tema de la quema".

De este modo, entre todos decidieron conformar la Mesa de Gestión Ambiental de Cruz Alta, una organización social interinstitucional y multidisciplinaria que reúne a los diferentes actores del sector público y privado de Tucumán con el objetivo de lograr la erradicación gradual de la quema de caña de azúcar en el Departamento.

Se trata de una organización entendida como una "disposición de relaciones entre componentes o individuos que produce una unidad compleja o sistema dotado de cualidades desconocidas en el nivel de los componentes o individuos [...] Asegura solidaridad y solidez a estas uniones, una cierta posibilidad de duración a pesar de las perturbaciones aleatorias. La organización, pues, transforma, produce, reúne, mantiene" (Morín, 1981: 126).

La Mesa está integrada por técnicos de distintas áreas y disciplinas del INTA (Programa Nacional de Cultivos Industriales, Caña de Azúcar, Gestión Ambiental, Sistema de Información Territorial, Comunicaciones, Forestales, Programas Pro Huerta y Cambio Rural, tanto de la EEA Famaillá como de la AER Banda del Río Salí); la Secretaría de Medio Ambiente, Dirección de Flora y Fauna, Dirección de Defensa Civil y Dirección de Fiscalización Ambiental del Gobierno de la Provincia de Tucumán; el Sistema Provincial de Salud (SIPROSA); la Asociación Bomberos Voluntarios de Las Talitas; la organización gremial Cañeros Unidos del Este; la Cooperativa La Merced; las empresas Juan José Budeguer, Los Cevilares y PAP Productores; y pequeños y medianos productores independientes. En el 2012 se sumó la Estación Experimental Agroindustrial Obispo Colombres, la Fundación PROYUNGAS y la Empresa Transener.

Entre el 2010 y 2012, el colectivo de actores de la organización llevó adelante un diagnóstico sobre la realidad de la quema de caña de azúcar en Tucumán y diseñó un programa para erradicarla, dentro del cual se elaboraron productos comunicacionales. Durante el proceso se realizaron reuniones periódicas 
y talleres en la sede de la AER Banda del Río Salí del INTA, ubicada en Pje. Alberdi 202, Banda del Río Salí, Cruz Alta, Tucumán. En dichos encuentros, al poner a dialogar las diferentes miradas, cada uno de los integrantes aportó su visión, experiencias e intereses sobre la problemática para pensar la transformación.

Así, la Mesa se constituye como un actor social cuyas prácticas se desenvuelven en el territorio de la Provincia de Tucumán, considerando que trabajamos con actores sociales en tanto sujetos colectivos. Samaja los describe de la siguiente manera: "los conglomerados de individuos (los grupos humanos, en todas las escalas) son entidades con determinaciones propias [...] son partes de un todo, y este todo existe y estabiliza patrones propios de acción mediante el doble mecanismo de conservar a sus componentes, pero a condición de suprimir su autonomía en aras de sus patrones normativos que son nuevos y superiores respecto de los patrones anteriores" (Samaja, 2003: 26).

Nos referimos a "grupos humanos que se unen para defender sus intereses y que obran utilizando el grado de poder que cada uno puede ejercer. Las tendencias (sociales, económicas, etc.) existen porque han sido el fruto de estrategias desplegadas por actores sociales. $Y$ si las rupturas a estas tendencias no han logrado hacerles cambiar su rumbo, ha sido porque el poder de estos actores sociales no ha sido suficientemente fuerte para aniquilarlas" (Mojica, 2005: 114). Éstos se desenvuelven "en el marco del dinamismo de la sociedad y de la historia, porque los actores sociales son agentes de intereses particulares en la sociedad" (Uranga, 2008: 13).

\section{Caracterización de los actores de la organización}

En un trabajo reciente, Claudia Villamayor (2008: 1) rescata la siguiente carta enviada por una persona de la nación mapuche a un grupo de comunicadores de una organización dedicada a la comunicación educativa:

"Un mundo es un planeta, un universo, un grupo, una aldea. Un mundo es una identidad. Hay muchos mundos. No somos iguales y las maneras de entender se construyen con las historias de quienes somos, qué hacemos y cómo vivimos, no sólo de cómo pensamos. Un mundo, no es todo el mundo. Un mundo, es el tuyo y el mío, el de muchos. Si no se ponen a dialogar, si no pueden escucharse en un mismo pie de igualdad, 
aunque uno se escriba y el otro viva en la voz hablada, prima uno sobre el otro y lo domina. Construir en la diferencia es saber escuchar todos los mundos para definir muchas formas de ver y de actuar. Naides es más que naides. F.H"

Estas palabras nos llevan a pensar en la complejidad en la que se desenvuelve el funcionamiento de una organización interinstitucional y multidisciplinaria como la Mesa de Gestión Ambiental de Cruz Alta, cuyas prácticas se construyen a partir de las diferentes miradas e intereses de sus miembros.

Por eso, lo primero que necesitamos conocer de la Mesa para realizar un diagnóstico comunicacional sobre ella es a los actores que la integran dentro de las dimensiones contextuales en las que se encuentran insertos, en el marco de las relaciones de unos con los otros, comprendiendo los significados que se construyen en esa interacción en situaciones concretas. Debemos identificarlos a partir de su identidad, considerando su visión sobre la problemática y los intereses que lo llevan a formar parte de la organización, todo ello enmarcado en las relaciones de poder que se tejen en esa vinculación.

Para hacerlo, Claudia Villamayor (2006: 5) nos propone "salir de la perspectiva de los modelos para encaminarnos en la mirada de un nuevo paradigma complejo, diverso y múltiple que nos invita a trabajar en el camino de primero que nada saber escuchar lo que las personas que animan un proyecto tienen para decir"

Es importante considerar que cada actor explica, reconoce y comprende a su modo la situación, a partir de su historia, motivaciones, propósitos y su posición relativa dentro de la situación. "Los seres humanos actuamos de acuerdo al significado que le adjudicamos a nuestras condiciones materiales de existencia. ¿Qué significa esto? Acordemos inicialmente que todo objeto se constituye sólo como objeto de discurso. Es decir: no es posible concebir un objeto al margen de la producción social de sentidos [...] Las percepciones, concepciones y evaluaciones son siempre vividas por alguien en particular y constituyen una forma de reafirmación de cada una de las personas en relación con su contexto" (Villamayor, 2002: 7-8).

En el ámbito de las prácticas sociales, cada actor construye su realidad y sus relaciones a partir de las matrices socio-culturales que lo atraviesan, entendidas como "el esquema básico que describe los rasgos principales de la lógica de 
funcionamiento de un grupo social. Una matriz sociocultural programa en cada grupo su sistema de percepción-acción. Incluye no sólo las condiciones, sino la percepción que cada grupo tiene de ellas (lo simbólico y lo material imbricados)". Esto implica "pensar lo social como una manera de trabajar las relaciones que conservan cierta estabilidad en los sectores o grupos socioculturales como formas que dan cuenta de una trayectoria, una genealogía en la historicidad de los vínculos" (Massoni, 2007: 31).

Por ello, en este apartado nos proponemos conocer a los sujetos de la Mesa de Gestión a través de la formulación que hacen de su mundo, mediante el lenguaje, y de las acciones que llevan adelante en situaciones concretas para ver cómo se vinculan esas formulaciones con esas acciones.

Veamos entonces cómo se constituye cada actor de la Mesa de Gestión a partir de su estructura, misión y funciones como institución, además de su mirada sobre la problemática y las propuestas que hizo para abordarla dentro de la organización. Para obtener la información, utilizaremos los audios que quedaron registrados de las reuniones. Las técnicas de investigación serán la observación participante y el análisis del discurso para abordar los relatos de los sujetos.

A lo largo de la historia de la Mesa se fueron sumando actores con diferentes grados de participación. Los principales, considerando aquellos que tuvieron un activo trabajo en la organización desde el momento en que se sumaron, son: el INTA; la Dirección de Defensa Civil; el Sistema Provincial de Salud; las empresas Juan José Budeguer, Los Cevilares y PAP Productores; la organización gremial Cañeros Unidos del Este; la Dirección de Fiscalización Ambiental; la Asociación Bomberos Voluntarios de Las Talitas; la Estación Experimental Agroindustrial Obispo Colombres; la Fundación PROYUNGAS; la Secretaría de Medio Ambiente y la Empresa Transener.

La Mesa también contó con la presencia de actores secundarios, que formaron parte de la organización con una baja participación en algunas de las reuniones. Ellos son la Dirección de Flora, Fauna Silvestre y Suelos de Tucumán y la Cooperativa La Merced.

\section{Dirección Provincial de Defensa Civil}

Este organismo depende de la Secretaría de Estado de Servicios al Ciudadano del Ministerio de Seguridad Ciudadana del Gobierno de la Provincia de 
Tucumán. El Director de Defensa Civil es el Ing. Fernando Jorge Torres. La misión es la de asistir al Señor Gobernador de la Provincia en todo lo relativo a la planificación, organización, coordinación, promoción, dirección y control de la defensa civil y, eventualmente, en la conducción de las operaciones de emergencia dentro del ámbito provincial, conforme a las directivas e instrucciones impartidas por el Ministerio de Defensa.

De acuerdo a la Ley Provincial de Defensa Civil No 3921 y su Decreto Reglamentario 2036/14, se entiende por Defensa Civil la parte de la Defensa Nacional que comprende "...el conjunto de medidas y actividades no agresivas tendientes a evitar, anular o disminuir los efectos que la guerra, los agentes de la naturaleza o cualquier desastre de otro origen puedan provocar sobre la población y sus bienes, contribuyendo a restablecer el ritmo normal de vida de las poblaciones afectadas..."

El organismo cuenta con una serie de servicios de protección civil como alerta, alarma y comunicaciones; orden; transporte; contraincendio y salvamento; asistencia sanitaria; asistencia social; e ingeniería y rehabilitación de servicios. Se trata de organismos especializados que cumplen su cometido en las emergencias, en base a planes y procedimientos operativos preestablecidos. Por otra parte cuenta con servicios auxiliares como la Cruz Roja Filial Tucumán; Scoutismo; Radioaficionado; y Bomberos Voluntarios ${ }^{33}$. Son instituciones constituidas por voluntarios que tienen como única finalidad servir a la comunidad para atender las necesidades públicas.

La Dirección Provincial de Defensa Civil forma parte de la Mesa de Gestión Ambiental de Cruz Alta desde su conformación en el año 2010. Lo hace a través del Ingeniero Mecánico e Ingeniero en Higiene y Seguridad César Acuña, Subdirector del organismo.

Según el funcionario, la misión de Defensa Civil ante una quema de cañaverales es la de coordinar todas las acciones para estar antes, durante y después del fuego.

En la primera reunión de la Mesa (21 de mayo de 2010), César Acuña sostenía que la quema de caña genera un peligro para la población: "Tenemos que definir primero la palabra peligro y riesgo. Peligro es aquello que de continuar

\footnotetext{
33 Tucumán cuenta con 14 asociaciones de bomberos y 4 en formación, nucleadas en la Federación Tucumana de Bomberos Voluntarios.
} 
amenaza la vida en forma directa. Y riesgo es aquello que con precaución se puede evitar. En cuanto al incendio de cañaverales, puede pasar de la fase agrícola a la fase urbana o a las localizaciones aisladas de casas. Entonces, estamos en presencia de peligro. Luego, tenemos el escalón anterior que es cuando se produce el fuego y se está dando riesgos de enfermedades, accidentes y de afectar otros tipos de bienes, ya no la vida, pero si una máquina, por ejemplo".

Por lo tanto, planteaba que los productores son los responsables de controlar sus campos para evitar este peligro: "voy a poner un ejemplo claro. Si tengo un auto, ese auto está registrado, tiene una tarjeta verde y es mío. Yo soy el responsable de eso. Si sube cualquiera en ese auto y mata a una persona, yo soy el responsable económicamente por lo que ha hecho el auto. Entonces, ustedes que son productores y tienen esas hectáreas son responsables económicamente por lo que pase ahí. Por lo tanto, uno tiene que vigilar las cosas propias".

Según el discurso del funcionario en ese momento, el interés de Defensa Civil de formar parte de la Mesa estaba centrado en que se puedan evitar las quemas debido a la escasez de recursos y tiempo de acción de los bomberos que son voluntarios. "Los recursos para actuar en contra del fuego son muy limitados. Están basados en 3 autobombas de la policía que está en San Miguel de Tucumán y otra que está en Concepción. Son los cuarteles oficiales. Después tenemos 10 cuarteles a lo largo de la provincia. Alderetes y La Florida están para trabajar en esta zona caliente que ustedes plantean. Tenemos una fuerza muy limitada, que se dirige a donde realmente existe el peligro. Entonces, nosotros ante la denuncia evaluamos la situación, preguntando al comisionado municipal de qué se trata y cuál es la magnitud, y dependiendo de eso actuamos o no".

\section{Sistema Provincial de Salud}

Dependiendo del Ministerio de Salud Pública del Gobierno de la Provincia de Tucumán, su Presidente es el propio Ministro, Dr. Pablo Yedlin. La misión del organismo es asegurar el mayor nivel de salud posible de las personas, las familias, la comunidad y el ambiente, mediante servicios de calidad, tanto preventivos como curativos y de rehabilitación, independientemente de la fuente de financiamiento, para lo cual, en relación a asuntos sanitarios, convocará a los sectores público y privado y a todas las fuerzas sociales. 
Dentro de su competencia se encuentra la tarea de organizar e instrumentar la promoción, protección, reparación y rehabilitación de la salud física y mental de la población y cualquier otra prestación y servicios de salud en relación con el ambiente; promover el dictado o dictar, según el caso, las normas necesarias para la ejecución de lo establecido en los artículos $2^{\circ}$ y $3^{\circ}$ de la Ley № 5.652 del 08-1084 y fiscalizar su cumplimiento; orientar la educación y promoción de la salud para generar en la comunidad una conciencia sobre el valor personal y trascendente de la vida humana y de la necesidad de su participación solidaria en el logro de su máximo bienestar; lograr el acceso de la población a una asistencia médica integral que contemple sus aspectos físico, mental, higiénico-ambiental y estético, a través de una medicina humanizada, oportuna, eficaz y participativa, atendiendo siempre a la condición humana de sus destinatarios y desterrando todo privilegio basado en la situación económica o social de los mismos; entre otros.

La estructura del SIPROSA se divide en 4 Áreas Programáticas: Oeste, Este, Sur y Centro. En la Mesa de Gestión Ambiental de Cruz Alta participa el Área Programática Este, cuya Directora es la Dra. Irma Díaz. Ésta cuenta con 13 áreas operativas (Banda del Río Salí, Burruyacú, El Bracho, El Timbó, Estación Aráoz, Garmendia, La Florida, La Ramada, Leales, Los Ralos, Ranchillos, Alderetes y Bella Vista) donde se ubican los hospitales y los Centros de Atención Primaria de la Salud (CAPS). Cada una de ellas tiene un Supervisor de Agentes Sanitarios (AS) de Áreas Operativas que tiene a su cargo a los agentes de terreno; todos ellos responden al Supervisor de Agentes Sanitarios del Área Programática Este, Sr. Domingo Mirk.

El Agente Sanitario es un trabajador que ejecuta la estrategia de Atención Primaria de la Salud, mediante acciones de promoción, protección y recuperación de la salud. Es el contacto directo entre la población y los servicios de salud. Trabaja con la comunidad dentro de un área programática, tanto en el hospital como en visitas domiciliarias o escolares programadas.

Desde esta estructura de funcionamiento, el Área Programática Este del SIPROSA participa en la Mesa de Gestión desde el comienzo, específicamente a través de sus agentes sanitarios. El representante del organismo es el Sr. Ariel Leiva, Supervisor de Agentes Sanitarios del Área Operativa Los Ralos con sede en el Hospital Los Ralos.

En cuanto a su visión sobre la quema de cañaverales, en la reunión del 21 de mayo de 2010, el Agente Sanitario planteaba que la sociedad conoce un sólo 
punto de vista de la problemática y está en contra de los productores, situación impulsada por los medios de comunicación. "Yo voy a dar un punto de vista que no es técnico. Nosotros hemos padecido el incendio en Los Ralos en el 2009 y vemos que ha habido un cruce de información mala en los medios de comunicación. Creo que ha habido un solo punto de vista en el tema de que vos ves la tele y la propaganda que sale directamente dice que se prohíbe a los productores quemar caña [...] Por eso es que la gente está en contra de los Budeguer, de todos los productores, porque a la gente vos le decís que están quemando caña y todos se les van a ir encima porque en la misma tele te están diciendo que el productor está quemando para ahorrar plata. Eso es lo que yo sabía hasta ahora y es la primera vez que veo el punto de vista de los productores [...] Ahora acá me entero que es una tradición". A su vez, Ariel sostenía que "yo vivo en el pueblo y muchas veces los chicos queman la caña".

Por ello, su relato en la reunión demostraba que la preocupación en integrar la Mesa era que se puedan prevenir los incendios con difusión y concientización, pero logrando que la comunidad conozca los diversos puntos de vista de la problemática. "Me parece lógico que haya una contrapropuesta en el sentido éste de la difusión de información para llegar a una prevención en esto, pero escuchando también el punto de vista del productor [...] Se tiene que apuntar a la difusión y concientización. Creo que tiene que haber una difusión masiva, pero mirando de ambos lados, que hay gente que directamente no puede llevar a cabo otro proceso más que éste para se lo contemple".

\section{Empresa Agrícola Juan José Budeguer}

Funciona desde el año 1974 con una sede ubicada en la localidad Banda del Río Salí, Tucumán. Es la empresa con mayor superficie de caña de azúcar del Norte Argentino con unas 10.000 hectáreas aproximadamente. Otra de las actividades principales es la producción de soja, contando con alrededor de 6.000 hectáreas.

Todo el proceso de producción de la caña es realizado con maquinaria propia de última tecnología. El sistema de cosecha utilizado es el mecánico. Sumado a esto, la rotación de caña con ganadería y granos como maíz y trigo le permite prescindir del uso del fuego en la cosecha y poscosecha.

Claramente, la Empresa Agrícola Juan José Budeguer se encuentra dentro del grupo de los grandes productores caracterizados en nuestra tesis por tener más 
de 500 hectáreas producidas, practicar una agricultura empresarial diversificada con otros cultivos, contar con un nivel alto en tecnología y mecanización y tener equipamiento y logística propia para los servicios de plantación, cultivo y cosecha.

El representante de la empresa en la Mesa de Gestión es su jefe de campo, el Ingeniero Agrónomo Mariano Abregú, que participa desde la conformación de la organización hasta la actualidad.

Con respecto a su mirada sobre el uso del fuego, en la segunda reunión (8 de junio de 2010), el técnico explicaba que ellos no utilizan la quema de caña ni de rastrojo en sus campos, pero que sufren la quema vandálica de los vecinos: "Nosotros hace algunos años ya que cosechamos todo completamente en verde, hemos incorporado la tecnología para trabajar en verde. Para nosotros la maloja tiene un valor, no de renta sino agronómico como mejorador de suelo y todo lo demás. Y nos vemos envueltos en un montón de situaciones, sobre todo porque estamos rodeados de casas [...] Ya son muy pocos los cañeros que realmente queman en la cosecha semimecanizada, pero los incendios se producen, donde hay más población hay más incendios. A veces no hay mala intención, pero hay personas que viven en una casa en el campo rodeada de caña, donde normalmente hay animales, y buscan que se le saque rápido esa caña y la forma más fácil es ir y prender fuego".

Abregú planteaba que el endurecimiento en la aplicación de la ley provincial que prohíbe la quema en el 2009 hizo que los productores no se quedaran en los campos para controlar el fuego, lo que aumentó la superficie quemada en la Provincia. "La ley si lo encuentra a uno en el lugar del incendio lo lleva preso. Nosotros hemos abandonado incendios que no habíamos provocado y dejamos que se queme porque si estábamos ahí nos llevaban presos".

Ante ello, consideraba necesario que se modifique la ley para autorizar a que el cañero pueda estar con su gente en el lugar del incendio para apagar el fuego. "Cuando hablamos de lo que se dispone para atacar un incendio en el campo, como son los bomberos, es muy poco. Y, por otro lado, un camión de bomberos con las características que tiene no está preparado y capacitado para transitar por donde hay caña. Creo que el que más capacitado está para atacar el fuego es el productor cañero. Antes cuando se quemaba no había inconveniente porque el cañero sabía a qué hora quemar, cómo iba a quemar, dónde iba a poner su gente y no había inconvenientes grandes. Yo creo que es muy importante el hecho de que uno esté 
en el lugar para tratar de apagar. Y a veces para apagar hay que prender, hacer un contrafuego, es lo único que puede controlar un incendio de cañaverales. No hablamos de bomberos, ni agua, hay que hacer un contrafuego y circunscribir el fuego hacia una zona que no sea combustible".

Por otra parte, manifestaba que su mayor interés era poder trabajar en la parte de educación: "Hay que educar en las escuelas, en todos lados, hay que educar porque es la base de todo el cambio".

\section{Empresa Los Cevilares S.A.}

La empresa cañera funciona desde el año 1984 en Tucumán, cuyo domicilio fiscal figura en la calle Federico Kossel s/n, Colombres, Cruz Alta. Con una planta de 50 personas trabajando en temporada alta y 36 en época baja, produce azúcar en 2.000 ha de caña ubicadas en los departamentos Cruz Alta, Burruyacú y Leales.

Los Cevilares cuenta con maquinaria propia para realizar las actividades de plantación, cultivo y logística. Para la cosecha de la caña utiliza el sistema mecánico, que es tercerizado. Toda la producción se comercializa con un solo ingenio, Los Balcanes. El cultivo de la caña es rotado con la producción de cereales como soja, trigo y maíz.

De este modo, la empresa forma parte del grupo de los grandes productores caracterizados en nuestra tesis por tener más de 500 hectáreas producidas, un alto nivel tecnológico y mecánico de su maquinaria y la realización propia de los servicios del cultivo.

Desde el año 2010, el Ingeniero Agrónomo Emiliano Hernández, Jefe de Campo de la empresa, integra la Mesa con una constante participación. En su opinión sobre la problemática, en la reunión del 21 de mayo de ese año destacaba que "hay una condena social hacia lo que ha sido la producción de caña [...] Estamos condenados socialmente, que es lo peor, porque estamos luchando contra eso también".

Por otra parte, expresaba una fuerte crítica a la ley provincial que prohíbe la quema. "Hay una ley con una prohibición hacia una práctica que venía instalada en un cultivo y es muy difícil cambiar una idiosincrasia de producción de un año a otro y, muchos más, imponiéndola como es el caso de esta ley que venimos viendo. Sobre todo en muchas zonas con productores medianos y chicos que hacen 
cosecha semimecanizada y se han visto totalmente imposibilitados de hacerla. El año pasado estaba prohibida la quema, entonces muchos productores prepararon su caña y la quemaron a escondidas o en horarios indebidos, lo que ha sido gran parte de los descontroles".

En este sentido, junto a otros productores cañeros e instituciones de investigación, llevó una fuerte lucha por la modificación de la ley desde que se implementó en el año 2007, pero sin lograr resultados. "Nosotros, un grupo de productores con gente del INTA y la EEAOC hemos venido durante dos meses reunidos con la Secretaria de Medio Ambiente [...] Esos dos meses hubo 3 reuniones con la Comisión de Medio Ambiente de la Legislatura, en la última reunión volvimos a cero porque no hubo una decisión de un cambio o de flexibilizar algunos puntos".

Por ello, el mayor interés que manifestaba el empleado de Los Cevilares con su participación en la Mesa era poder trabajar para que se contemple la quema controlada de rastrojo para la renovación del cultivo y de caña en situaciones particulares donde los productores medianos y grandes necesitan utilizar la cosecha semimecánica. "No proponemos que se derogue la ley para seguir quemando, sólo planteamos algunos puntos como el caso de la cosecha semimecanizada que por superficie, pendientes, piedras o problemas de piso porque hay napas altas se sigue haciendo. $Y$ si se quiere seguir haciendo caña no hay otro método y no creo que lo haya, son situaciones que lo requieren [...] Pedimos casos puntuales para la época de renovación de cañaverales. Es un $20 \%$ de la superficie que se renueva cada año, son unas 40.000 has".

\section{Empresa PAP}

El domicilio fiscal de esta empresa cañera es Balcarce 806, San Miguel de Tucumán, donde cuenta con 7 empleados de campo permanentes, 24 temporarios y 5 administrativos.

PAP tiene una superficie total de 1.120 has destinadas al cultivo de la caña de azúcar, distribuidas en los departamentos de Cruz Alta, Lules y Leales. Las actividades de plantación, cultivo y cosecha son realizadas por la misma empresa, para lo cual cuenta con 4 cosechadoras integrales, 15 tractores e implementos propios. La comercialización de toda la producción se realiza con el Ingenio Concepción. Se utiliza la rotación con otros cultivos como soja, trigo y maíz. 
En cuanto a la Responsabilidad Social Empresaria, sólo tiene una participación indirecta con las comunas y escuelas de las zonas colaborando con donaciones cuando éstas lo solicitan.

De acuerdo a estos datos, la empresa PAP se ubica claramente dentro del grupo de los grandes productores cañeros. En representación de este sector, el Perito Agrónomo Manuel Ponce, encargado de producción de caña de azúcar de la empresa, participa en la Mesa de Gestión desde su constitución en el año 2010.

Con respecto a su visión sobre la quema, el representante de PAP planteó varias cuestiones que quedaron manifestadas en sus relatos: el mayor problema es el rastrojo, por lo que se debe legislar específicamente en esa temática; no todos los cañeros pueden acceder a las tecnologías disponibles para no quemar; los productores sufren las quemas vandálicas por parte de la población; la quema genera pérdidas para los productores; la legislación también debe contemplar la situación de los medianos y grandes productores. Por ello, su intensión en la Mesa es poder trabajar en alternativas que permitan abordar estas situaciones con una mayor incidencia en los ámbitos gubernamentales que tienen injerencia directa en la problemática.

Manuel Ponce lo expresaba de la siguiente manera en la primera reunión de la Mesa (21 de mayo de 2010): "Hay que recalcar qué es una caña en pie y qué son los rastrojos para que empecemos a diferenciar y se pueda legislar puntualmente sobre qué es cada cosa. De un cañaveral el $75 \%$ es caña, de lo cual se extrae el azúcar, y el 25\% es rastrojo, considerado hasta hace no mucho tiempo basura. Hoy el problema que nos acusa es el tema del rastrojo en el campo. A través de la colaboración de la Experimental o del INTA con algunos trabajos estamos buscando darle el valor que tiene el rastrojo ya sea como cobertura para mantener la humedad, en el control de plagas, como materia prima para calderas, alimentos para ganado, mulching ${ }^{34}$ en otros cultivos. Todas estas acciones podrían dar una solución mediante investigación e inversión. La investigación es porque todas estas cosas que se están haciendo en el sector, técnicamente no tienen un ok de que vayan a darnos una solución".

En cuanto a las quemas accidentales o intencionadas de los pobladores sobre los cañaverales, sostenía que "uno está parado en cualquier rincón de

\footnotetext{
${ }^{34}$ El mulching hace referencia al uso de la maloja como acolchado vegetal para proteger a los cultivos de las temperaturas extremas del ambiente e incorporar materia orgánica al suelo. De este modo, reemplaza el uso de la cobertura plástica que tiene poca durabilidad y difícil reciclaje.
} 
Tucumán, por la distribución demográfica, y anda uno en bicicleta o en un carrito en el cerco. Ese tipo, sin quererlo, fumando, deja mal apagado un pucho. O se ha hecho un mate cocido y deja mal apagada la leñita. Los cosecheros de limón que si ustedes pasan los ven que se hacen un fueguito. Bueno, esos tipos dejan focos de incendio. Hay gente que barre el parque y quema las hojas".

Con respecto a las pérdidas de azúcar que se generan con las quemas, Manuel señalaba que "el fuego te empieza a manejar la cosecha. No es que el productor quema para cosechar. Una vez que está quemada, hagan de cuenta que han marcado una cuenta regresiva, a medida que van pasando las horas, días, semanas se pierde más".

\section{Cañeros Unidos del Este}

Es una asociación gremial con personería jurídica, que fue creada en el año 2009 y cuenta con unos 100 afiliados entre pequeños y medianos cañeros del Este de la Provincia. Su presidente es el Sr. Mario Tizeira, actual Delegado Comunal de Los Ralos y Presidente de la Cooperativa La Merced.

Cañeos Unidos del Este (CUE) expresa la voluntad de acompañar al cañero, luchar por sus intereses y brindarle un servicio para que mejore su producción. Para ello brinda asesoramiento técnico a sus afiliados y actúa como mediador ante posibles conflictos entre el productor y los ingenios.

La Comisión Directiva de la organización realiza reuniones semanales donde se tratan los temas económicos y productivos de interés para el sector y se definen los futuros movimientos gremiales.

El CUE es uno de los actores que tiene varios productores medianos y grandes como representantes en la Mesa desde que se conformó en el 2010. Los que tuvieron una mayor participación en las reuniones fueron el ingeniero agrónomo Roque Budeguer y el ingeniero agrónomo Walter Roda.

En su visión sobre la problemática, en las diferentes reuniones el CUE reconoció las dificultades que presentan actualmente los pequeños productores para erradicar la quema de acuerdo a la legislación vigente.

En este sentido, en la reunión del 8 de junio de 2010, el ingeniero Roque Budeguer explicaba que "estamos viendo que los pequeños productores, los que tienen de 50 has. para abajo, dedican su fundo a la cosecha semimecanizada. Hoy 
por hoy, esos pequeños productores no tienen otra alternativa, desde el punto de vista económico, que hacer este tipo de cosecha donde para ahorrar costos y para que el ingenio le pueda recibir esa caña y no tenga demasiada basura o todo el rastrojo que está quedando recurren al fuego. Entonces estamos hablando de dos cosas: la parte cultural y la parte económica de esos productores".

En cuanto a su interés de participar en la Mesa, Budeguer esperaba que se pueda rever la dureza de la implementación de la ley en el 2009. Y lo expresaba de la siguiente manera: "El año pasado el fuego se fue totalmente de las manos. No se podía mandar a ningún empleado a apagarlo porque lo llevaban preso. Todos los años atrás, el que quemaba cuidaba su lugar y trataba de que no pase. Desde el año pasado que fue la implementación de esta ley tan fuertemente aumento bruscamente las quemas. Yo creo que hay que buscar una alternativa".

Por otra parte, opinaba que se debía trabajar en educación con los productores y los niños de las escuelas para evitar las quemas vandálicas que sufren los cañeros en sus campos. "La formación y la educación, es lo único que va a dar resultados, la formación de los productores y de la sociedad".

\section{Dirección Provincial de Fiscalización Ambiental}

Depende de la Secretaría de Estado de Medio Ambiente del Ministerio de Desarrollo Productivo del Gobierno de la Provincia de Tucumán. La funcionaria a cargo es la Dra. Gladys Susana Meoni de López.

La misión del organismo es la de asistir a la Superioridad en todo lo inherente a la fiscalización de las condiciones relativas a la calidad de los recursos naturales disponibles, a fin de alcanzar un ambiente sano, equilibrado y apto para el desarrollo humano.

Entre sus funciones se destaca la de entender en la fiscalización del cumplimiento de las normas relacionadas con la contaminación ambiental; coordinar actividades para la fiscalización del ambiente con municipios, comunas rurales y otros organismos gubernamentales; realizar la supervisión y auditoría ambiental en establecimientos industriales y agropecuarios y lugares en donde por las actividades humanas o fenómenos naturales, se requiera del diagnóstico ambiental; realizar auditorías integrales, evaluaciones ex post de impacto ambiental, evaluaciones de los servicios públicos y privados que tengan relación con los temas ambientales. 
Además, hace referencia específicamente a ejercer los controles establecidos en la Ley № 7.459, relacionada con la quema de vegetación en general y de caña de azúcar en particular; y en la Ley № 7.873, vinculada con la prohibición a todos los Ingenios de recibir caña de azúcar quemada y cosechada con máquinas integrales. En ambos casos se constituye como la autoridad de aplicación de dichas leyes.

De este modo, se visibiliza el rol fundamental que cumple la Dirección de Fiscalización Ambiental en la problemática de la quema de caña como autoridad de aplicación de las legislaciones provinciales que regulan esta práctica.

Los primeros representantes de este organismo del Estado que se sumaron a la Mesa en el año 2011 fueron el Técnico Universitario en Higiene y Seguridad en el Trabajo Héctor Orlando Medina, Inspector a cargo del tema quema de caña en la Dirección, y la Lic. Química Natalia López, que ocupa el cargo de Analista de Laboratorio y Responsable de Muestreo de Aire. Y, en el 2012 se sumó el abogado Facundo Moreno, que forma parte de la asesoría jurídica del organismo, cumpliendo la función de levantar las actas de infracciones para la aplicación de las sanciones establecidas en la legislación vigente.

En cuanto a su visión sobre la problemática, en las reuniones ellos aclararon que su competencia es aplicar las sanciones administrativas, no penales, ante la infracción de una quema. También, reconocieron que cuentan con escaso personal para realizar esta tarea, que consiste en levantar actas e iniciar el proceso judicial ante casos de quema contemplados en uno o más de los 6 puntos del Art. 9 del Decreto $N^{\circ} 795 / 3$ donde se prohíbe absolutamente la quema.

En este sentido, en la reunión del 9 de agosto del 2012, Facundo Moreno explicaba: "nosotros somos como un brazo fiscalizador. Llegamos cuando ya el fuego está apagado y tenemos que levantar el acta. Es difícil con los recursos que tenemos poder cumplir, desde la Dirección de Fiscalización Ambiental, con la función sancionadora. Yo no doy abasto de sacar expedientes con actas [...] El decreto siempre termina en una prohibición absoluta, por más que prevé un plan y se discuta sobre las autorizaciones a los pequeños productores. Termina el Art. 9 del decreto con una prohibición de $6 \operatorname{casos}^{35}$ en que no se puede quemar sin

\footnotetext{
${ }^{35}$ Los seis casos de prohibición absoluta de la quema están referidos en las páginas 32 y 33 de la tesis.
} 
autorización o con autorización intermedia de un ente u otro del Estado; que creo que son los casos en los que está comprendido el 95\% de las quemas".

Pero, desde el organismo también reconocieron el esfuerzo de algunos productores por dejar de quemar. Héctor Medina, en la misma reunión, explicaba lo siguiente: "la experiencia nuestra nos dice que hay productores que están preocupados por este tema por solucionarlo. Yo creo en el esfuerzo del gran cañero en estos días. Pero hay situaciones donde nosotros tenemos el registro de un tipo que estaba quemando y a los 50 metros estaba todo el tren de cosecha ya armado, lo tenemos fotografiado, estaba perfecto. Eso ocurre, pero no quiere decir que sean los generalizados".

\section{Asociación de Bomberos Voluntarios de Las Talitas}

Fue creada el 3 de agosto de 2003 y cuenta con personería jurídica desde el 4 de diciembre de ese mismo año. Su sede está ubicada en la calle 10 № 452 de Villa Mariano Moreno, Las Talitas. El área operativa o jurisdicción es la ciudad de Las Talitas y las localidades aledañas como Los Nogales, Los Pocitos, Timbó Viejo y Nuevo y la zona norte de San Miguel de Tucumán. Pero, en caso de ser convocados ante una emergencia deben acudir a cualquier zona de la provincia.

En la actualidad realizan su trabajo voluntario 28 bomberos y 20 cadetes de entre 12 y 16 años. La Comisión Directiva está integrada por 18 personas de la comunidad de Las Talitas, que también son voluntarios. Para ser bomberos, los aspirantes tienen una formación de un año con capacitaciones a cargo de los instructores de la institución y el jefe de cuerpo.

La Asociación cuenta con tres vehículos que fueron donados o adquiridos con fondos propios. El Móvil 1 para primeros auxilios, equipado con tablas de rescate, collarines inmovilizadores, maletín de primeros auxilios, matafuegos, botiquín, radio y antena. El móvil 2 es un camión con cisterna de 3.000 litros de agua, con una bomba de agua, mangas de diferentes medidas, lanzas, columna hidráulica, herramientas de sapa, sirena y escalera. El Móvil 3 es una camioneta cerrada que sirve para primera respuesta, rescate vehicular y todo tipo de incendios, ya que tiene un tanque de mil litros y una bomba de agua, mangas y lanzas.

Para acudir ante incendios estructurales, cada una de las dotaciones está integrada por 6 bomberos equipados con guantes, monjas casco, antiparras, botas, 
coquetón y pantalón. En el caso de incendios forestales, además, acuden con mochilas forestales. También tienen ropa adecuada para extracción y tratamiento de abejas, trajes de lluvia con botas, chaleco de estribación, férulas y equipos para rescate en altura con elementos para ascenso y descenso.

En cuanto al financiamiento, el Gobierno de la Nación y la Provincia les entregan un subsidio, una vez al año, sólo para equipamiento o herramientas de lucha contra el fuego. La comisión debe conseguir fondos para combustible, viáticos, alimentación, hidratación y limpieza de los equipos.

La Asociación de Bomberos Voluntarios de Las Talitas se integró a la Mesa de Gestión en el año 2011, a partir de la invitación de la Dirección de Defensa Civil de la Provincia. Sus representantes son Lourdes Fernández Poblete, Presidente de la Asociación, y Segundo Antonio González, Jefe de Cuerpo.

En cuanto a su visión sobre la problemática, ante su experiencia en terrero, desde la organización reconocieron que las quemas en Tucumán no son sólo de caña de azúcar y plantearon la falta de campañas de difusión en los medios públicos para evitar y bajar los altos índices de fuegos en la Provincia.

En la reunión del 4 de mayo de 2011, Lourdes Fernández explicaba que "como bomberos somos los servidores públicos voluntarios que salimos a esta lucha y problemática actual, que no solamente son de caña estos incendios, son también de pastizales, basurales. Ya es una cultura, es cultural el problema. Pese a que nosotros como bomberos voluntarios en la Provincia no contamos con una ley provincial ni tampoco estamos adheridos a una ley nacional, estamos cumpliendo la ley en su generalidad, salimos a hacer prevención y a erradicar y combatir esta lucha con el fuego. Los elementos que utilizamos, que son escasos, los estamos utilizando no en emergencias sino en esto que se puede evitar".

Por esto, expresaban su interés de participar en la Mesa para trabajar en campañas de prevención y programas para darle usos alternativos a la maloja a fin de disminuir las quemas. La bombera voluntaria sostenía: "nosotros queremos que también exista y se puedan implementar programas para poder utilizar estos residuos en otros derivados. Estamos conscientes y hemos visto que existen programas. INTA nos ha demostrado que la maloja puede ser utilizada en carbón vegetal, briquetas, o que se podría transformar esa maloja en energía o abonos". 


\section{Secretaría de Estado de Medio Ambiente}

La dependencia jerárquica del organismo dentro del Poder Ejecutivo es el Ministerio de Desarrollo Productivo del Gobierno de la Provincia de Tucumán. El Secretario de Medio Ambiente es el Ing. Alfredo Montalván.

Su misión es la de participar en la formulación, implementación, evaluación y control de las políticas, programas y proyectos vinculados a la preservación y protección ambiental, al desarrollo sustentable, a la utilización racional y conservación de los recursos naturales renovables y no renovables, a los recursos hídricos y mineros tendientes a alcanzar un ambiente sano, equilibrado y apto para el desarrollo humano, proponiendo y promoviendo estrategias dirigidas a un aprovechamiento integral y racional de los mismos.

Entre sus funciones se encuentra la de prevenir los efectos ambientalmente negativos, provenientes de los riesgos naturales y antrópicos con relación a la instalación de asentamientos humanos, infraestructura y emprendimientos económicos; contribuir a planificar y tomar decisiones de nivel estatal y privado, a partir del conocimiento del territorio, de los recursos y de la tecnología, en los distintos campos de la actividad humana, con énfasis en la sustentabilidad ambiental de las actividades; supervisar las actividades de auditoría ambiental y control en aquellos establecimientos que por sus actividades humanas o fenómenos se requiera del diagnóstico ambiental.

De estas funciones se desprende la responsabilidad que tiene la Secretaría de Medio Ambiente de Tucumán sobre la problemática de la quema de caña de azúcar, donde debe articular con los organismos públicos y privados para lograr soluciones ambientalmente sustentables.

Si bien al inicio de la Mesa de Gestión Ambiental de Cruz Alta, desde el organismo mostraron cierta resistencia para sumarse y apoyar las acciones que llevaba adelante, finalmente terminaron sumándose en el 2012 con la presencia de la abogada Florencia Sayago.

En cuanto a la visión sobre la quema, desde la Secretaría de Medio Ambiente reconocieron la complejidad de la problemática, considerando que el sector productivo no es el único responsable de los fuegos, y las dificultades económicas y tecnológicas de los productores para erradicar esta práctica. 
En este sentido, el Ingeniero Alfredo Montalván, Secretario de Medio Ambiente, en la reunión de la Mesa con la Comisión de Medio Ambiente de la Legislatura de Tucumán (3 de agosto de 2012) manifestaba lo siguiente: "entiendo que no es un problema sólo del sector. El $45 \%$ de los focos de incendio en la provincia tiene que ver con el sector cañero. El otro 55\% tiene que ver con otro sector que no es cañero. El $80 \%$ de ese 45 es quema de rastrojo, si hay algo que destacar que en el último tiempo es que vienen disminuyendo las quemas de caña en pie. Mucho de la problemática está enfocada en el rastrojo".

Por otro lado, planteaba la dificultad que significa para ellos tener que aplicar la ley que prohíbe la quema de vegetación en la provincia: "en su momento se nos cargó el peso de una ley difícil a la Secretaría de Ambiente. Es una ley compleja porque también está el Art. 186 del Código Penal, donde es un delito la quema de pastizales o de vegetación seca".

El funcionario también reconocía la dificultad de autorizar la quema controlada para los productores de menos de 50 hectáreas dentro de las excepciones de la ley. En este sentido, en la misma reunión sostenía que "la ley en ese aspecto es bastante ambigua, autoriza pero no autoriza. Por lo tanto, lejos está de parte nuestra que autoricemos. Si yo estuviese autorizando una quema controlada estaría chocando contra las normas y al mismo tiempo con una complicación desde el punto de vista penal muy compleja".

Ante ello, el interés que manifestaba la Secretaría de Medio Ambiente de Tucumán con su incorporación a la Mesa de Gestión Ambiental de Cruz Alta era poder avanzar, con el apoyo de todos los sectores representados en la organización, en una modificación de la ley en este sentido. Alfredo Montalván lo explicaba así: "cuando se hace un análisis de las legislaciones internacionales encuentra que la tendencia mundial es la eliminación de esta práctica. Allá, en algunos lugares del mundo donde se sigue con esta práctica como método auxiliar de la cosecha es bajo ciertos parámetros y condiciones que las instituciones del Estado regulan. Entiendo que esta Mesa ha avanzado mucho en esa dirección de poder decir bajo estas condiciones es posible. Pero nuestra ley no contempla nada de esto. Si en algún momento esta legislatura tiene que revisar parte de la norma tiene que ser en esa dirección". 


\section{Estación Experimental Agroindustrial Obispo Colombres}

La EEAOC es un ente autárquico del área del Ministerio de Desarrollo Productivo del Gobierno de Tucumán. Fue creada en el año 1909 con la misión de apuntalar tecnológicamente el temprano liderazgo agro-productivo de la provincia.

La gestión de la Institución es conducida por un Directorio "ad-honorem", integrado por 10 representantes de los diferentes sectores de la actividad agroindustrial tucumana. $Y$ se ejecuta a través de una Dirección Técnica, que cuenta con el apoyo de cuatro Directores asistentes para otras tantas áreas operativas: Tecnología Agropecuaria, Tecnología Industrial, Disciplinas Especiales y Administración y Servicios.

La tarea de investigación en la EEAOC se organiza en torno a programas de trabajo, que abordan grandes áreas temáticas definidas en el Plan Estratégico Institucional. Estos programas, que pueden articular a la vez subprogramas y/o proyectos puntuales orientados a aspectos más especializados del conocimiento, tienden al mejoramiento de la calidad y el rendimiento de los productos, la disminución de los costos de producción y el aseguramiento de la sustentabilidad de los sistemas agroindustriales, a través de la creación y el desarrollo de tecnologías y métodos -tradicionales o biotecnológicos- para un manejo eficiente de los cultivos y de sus industrias derivadas. Específicamente en caña de azúcar cuenta con dos programas: Caña de Azúcar e Industrialización de la Caña de Azúcar.

A esta estructura matricial se le suma la actividad de servicios destinados al sostenimiento de la producción, la formación técnica y la transferencia del conocimiento.

El ingreso de la EEAOC a la Mesa de Gestión se dio en el año 2012 con la incorporación del Ingeniero Agrónomo Juan Fernández de Ullivarri, investigador en caña de azúcar dentro del Área en Investigación y Tecnología Agropecuaria de la Institución.

En su opinión sobre la quema, el técnico de la EEAOC expresaba que es una problemática compleja, donde la responsabilidad no es sólo del sector productivo, sino también de la sociedad y las instituciones de investigación. Además, destacaba la fuerte demanda social que existe para que se elimine esta práctica. 
En este sentido, Juan Fernández de Ullivarri ${ }^{36}$ sostenía que "en Tucumán la quema era aceptada hace unos años como una práctica más de la cosecha de la caña. Actualmente, la sociedad está reclamando al sector azucarero y a las instituciones de investigación que esta práctica tradicional sea eliminada. La problemática de la quema es bastante compleja, ya que involucra, además de diversos actores (productores, contratistas, ingenios, investigadores, legisladores, etc.), factores climáticos y sobre todo culturales que tienen gran influencia en la incidencia de la quema. Actualmente, si bien la quema es un gran problema, la actividad se está dando cuenta que tiene que cambiar hacia una producción sin quema. Esto implica un cambio cultural del sector azucarero y también de la sociedad que tiene como costumbre el uso del fuego como método de limpieza".

Por ello, el interés de la Estación Experimental Agroindustrial Obispo Colombres de formar parte de la Mesa era poder trabajar con el resto de los actores involucrados en las cuestiones técnicas y de educación necesarias para eliminar la quema. "La eliminación de esta práctica va a ser completa cuando se terminen de solucionar algunos problemas técnicos, que son responsabilidad de las instituciones de investigación, y de educación de la sociedad".

\section{Fundación ProYungas y Defensoría del Pueblo de Tucumán}

La Fundación para el Desarrollo y la Conservación de las Selvas Subtropicales de Montaña (ProYungas) es una organización sin fines de lucro que lleva adelante actividades de gestión para la conservación y el desarrollo sustentable en la ecorregión de las Yungas o Selvas Subtropicales de Montaña y de otras áreas del subtrópico argentino.

Esta organización nació en el año 1999, a partir del Laboratorio de Investigaciones Ecológicas de las Yungas (LIEY) de la Universidad Nacional de Tucumán. Desde allí trabaja con la misión de promover acciones de conservación, desarrollo sustentable, capacitación, monitoreo socioambiental y difusión de las selvas subtropicales de montaña del Noroeste Argentino (Yungas) y otros ambientes del subtrópico argentino y países vecinos. Desde su creación, mantiene un diálogo abierto con los actores involucrados en el uso del territorio y en la toma de decisiones en las ecorregiones donde interviene. Sostienen que cuantos más actores compartan y se involucren activamente y desde sus diversos ámbitos a las

\footnotetext{
${ }^{36}$ Entrevista personal, 5 de agosto de 2012.
} 
acciones de conservación y desarrollo sustentable de las ecorregiones del subtrópico, mayores serán las probabilidades de tener éxito en la implementación de las mismas, en su magnitud, su alcance y su sustentabilidad en el tiempo.

Si bien la mayoría de las actividades de la Fundación ProYungas se llevan a cabo en los sectores Norte y Centro de las Yungas (Alta Cuenca del Río Bermejo, Provincias de Salta y Jujuy), durante los últimos años ha extendido sus actividades al sector Sur de las Yungas (Tucumán y Catamarca) y otras áreas del subtrópico argentino.

En este sentido, al conocer las actividades que llevaba adelante la Mesa de Gestión Ambiental de Cruz Alta en la provincia, el Secretario Ejecutivo de la ONG, Dr. Sebastián Malizia, decidió formar parte de la organización a partir de junio de 2012.

Como el abogado ${ }^{37}$ además trabaja en la Defensoría del Pueblo de Tucumán, propuso sumarla también a la Mesa: "Una vez interiorizado del trabajo que estaba haciendo la Mesa y de los integrantes de la misma, me pareció que sumar a la Defensoría del Pueblo era positivo, ya que por su rol institucional podía cumplir una función importante de concertación de ciertos actores. Estoy convencido que la Defensoría del Pueblo puede aportar a la solución de estos problemas como la quema de caña, corriéndose un poco de su rol tradicional de ente de control y funcionando también como organismo de concertación que ayude a definir e implementar políticas públicas".

La Defensoría del Pueblo de Tucumán tiene origen parlamentario y su funcionamiento está reglamentado en la Constitución Provincial. Tiene la misión de defender, proteger y promocionar los derechos humanos y demás derechos e intereses individuales o colectivos de los ciudadanos de acuerdo a la Constitución Provincial y Nacional, los Tratados Internacionales y las leyes frente a los actos, hechos u omisiones de la Administración Pública provincial y municipal o de prestadores de servicios públicos.

El Defensor brinda un servicio gratuito al ciudadano, pudiendo realizar investigaciones, inspecciones, verificaciones y cualquier otra medida probatoria que requiera el caso. También puede acceder a toda documentación relacionada con ese caso que investiga en el ámbito de la Administración Pública Provincial. Para

${ }^{37}$ Entrevista personal, 15 de agosto de 2012. 
hacerlo, el Defensor cuenta con un equipo interdisciplinario que se encarga de recibir y tramitar los reclamos para elaborar las propuestas de solución.

En representación de la Fundación ProYungas y la Defensoría del Pueblo, Malizia $^{38}$ sostenía que el problema de la quema de caña radica en que el uso del fuego está descontrolado, lo cual es responsabilidad de la sociedad y el Estado. "Creo que el problema existe no por el simple hecho de la quema sino porque el uso de esta práctica esta fuera de control. Ello sucede porque tenemos una sociedad bastante poco apegada a las normas, y no me refiero sólo a las escritas, sino también a ciertos conceptos básicos de civilidad; y una total incapacidad del Estado de controlar las conductas de los ciudadanos. Hay una incapacidad de la sociedad en general de sobreponerse, aunque sea por un instante, a sus propias necesidades inmediatas y pensar en el bienestar general. Creo que la quema en si no es un problema por sí solo. Creo que la forma en que se la utiliza y los casos en que se la utiliza es el problema. Necesitamos madurar como sociedad".

De este modo, el interés que lo llevó a participar de la Mesa era poder elaborar políticas que aborden la quema desde las diferentes perspectivas del problema. "Creo que la solución a la problemática que ocasiona la quema de caña o malhoja vendrá de la mano de la implementación de verdaderas políticas que contemplen el problema desde distintas perspectivas. Está claro que el Estado con el rol tradicional de control y sanción nada puede hacer frente a este tema. Sí deberá controlar el cumplimiento de esas políticas, pero la mera prohibición de una actividad que se ha popularizado por la misma permisividad del Estado creo no nos lleva a ningún lado. Hay que buscar soluciones alternativas que generen interés para el sector afectado y nos lleven a pensar más globalmente y no sólo como individuos".

\section{Transener S.A.}

La Compañía de Transporte de Energía Eléctrica en Alta Tensión Transener S. A. se define como la empresa líder en el servicio público de transporte de energía eléctrica en extra alta tensión en la República Argentina. Es operadora de la red nacional de transporte de energía eléctrica en extra alta tensión, integrada por casi 8.800 kilómetros de líneas de transmisión. A ello se suman los aproximadamente 5.500 kilómetros de líneas que componen la red de su controlada Empresa de

${ }^{38}$ Entrevista personal, 7 de agosto de 2012. 
Transporte de Energía Eléctrica por Distribución Troncal de la Provincia de Buenos Aires Sociedad Anónima Transba S.A.

La empresa tiene definidos su organigrama, visión, misión y valores como perfil corporativo. En este sentido, su visión es ser líderes en el transporte de energía eléctrica. La misión, asegurar la prestación del servicio que se comprometen a brindar, con un nivel de calidad, eficacia y eficiencia que satisfaga las expectativas de los clientes, agentes del mercado eléctrico, accionistas, empleados y de la comunidad a la que sirven.

Dentro de las actividades de Responsabilidad Social, la empresa TRANSENER lleva adelante actividades de concientización en establecimientos educativos y visitas en emplazamientos operativos. Además, brinda apoyo a entidades de bien público como centros comunitarios, establecimientos educativos y centros de salud.

Transener utiliza medios de comunicación como su página web. Como estrategia comunicacional cuenta con espacios de capacitación que brinda a la comunidad, para la cual utiliza productos como folletería institucional.

El Técnico Agropecuario Juan Izquierdo Debi, integrante del Departamento Tierras de la Gerencia de Ingeniería de Transener en Tucumán, se acercó a la Mesa de Gestión en el año 2012 y, desde ese momento, forma parte de la organización.

En la primera reunión que participó (9 de agosto de 2012), Izquierdo planteaba las dificultades que genera la quema de caña por los cortes en el suministro eléctrico, considerando que los medianos y grandes productores también queman la caña.

En ese momento, el técnico lo graficaba de la siguiente manera: "el año pasado tuvimos nueve salidas de servicio por quema de caña. Para nosotros, que haya fuego debajo de las líneas de alta tensión de 500 mil voltios y haga descarga es igual o superior a un rayo. De las nueve salidas de servicio, sólo dos fueron por productores chicos. Para nosotros el perjuicio más grande son los productores grandes. Cinco de las salidas la tuvimos con el Ingenio Concepción, que es un sólo propietario y bastante grande. El productor chico es cierto que no tiene otra alternativa que quemar, pero el productor grande también quema y mucho y por una conveniencia total económica, de donde lo mires, es económica”. 
En cuanto al interés que lo llevó a sumarse a la Mesa, explicaba que querían poder trabajar con los productores para que eviten quemar la caña debajo de los tendidos, además de que tomen las medidas para evitar las quemas accidentales o intencionadas de terceros dentro de sus campos.

Como mencionamos al inicio del apartado, en la Mesa participaron actores secundarios, es decir, aquellos que formaron parte de la organización con una baja participación en algunas de las reuniones.

\section{Dirección Provincial de Flora, Fauna Silvestre y Suelos}

Esta Dirección del Estado depende de la Subsecretaría de Asuntos Agrarios y Alimentos perteneciente a la Secretaría de Estado de Desarrollo Productivo del Ministerio de Desarrollo Productivo del Gobierno de la Provincia de Tucumán. El Director de Flora, Fauna Silvestre y Suelos es el Arq. Daniel Ricardo Manso.

La misión del organismo es administrar los recursos naturales renovables, mediante el establecimiento e implementación de políticas acordes a las normas de manejo, recuperación y conservación en la materia.

Entre las funciones que tiene, vinculadas a su participación en la Mesa de Gestión Ambiental de Cruz Alta, se destaca la de aplicar y hacer cumplir la legislación vigente en la materia, proponiendo las modificaciones necesarias para el adecuado manejo de los recursos naturales renovables; ejecutar los planes inherentes al aprovechamiento y manejo de los recursos naturales renovables; mantener vinculaciones con instituciones públicas o privadas, nacionales, provinciales y organismos internacionales, relacionadas con sus funciones específicas; concientizar a la población acerca de los problemas derivados de la degradación de los suelos, realizando campañas de educación y difusión, en coordinación con los organismos competentes.

De este modo, cuando el INTA convocó a los actores del territorio para analizar la problemática de la quema en el año 2010, desde el Ministerio de Desarrollo Productivo de la Provincia enviaron al Técnico César Costas de la Dirección de Flora, Fauna Silvestre y Suelos para que los representara. Pero, sólo participó de manera intermitente, en algunas de las reuniones. Además, fue la única de las direcciones dependientes del organismo que se sumó. 


\section{Cooperativa La Merced}

Esta organización de productores cañeros está formada por 30 socios y cuenta con aproximadamente 800 ha en total. Su centro de operaciones se ubica en la Comuna Rural Los Ralos, Departamento Cruz Alta, donde además viven las familias socias constituyendo una pequeña comunidad. Son devotos de la Virgen La Merced, por ello la Cooperativa lleva su nombre.

El presidente de la organización es el Sr. Mario Tizeira, con una fuerte incidencia política, ya que además es el Presidente de la organización Cañeros Unidos del Este (CUE) y el Delegado Comunal de Los Ralos desde el año 2011.

Desde hace más de 20 años, destina sus 800 ha ubicadas en la Localidad de Los Ralos al cultivo de la caña de azúcar. En los últimos años comenzaron a incorporar la rotación con soja para limpieza del terreno, fertilidad, etc. La Cooperativa cuenta con toda la maquinaria para las tareas de plantación y cultivo, que son realizadas por los miembros de las familias socias. Pero, la actividad de cosecha es realizada por contratistas con el sistema mecanizado.

De este modo, al unirse los productores a esta Cooperativa lograron constituirse como una Explotación Agropecuaria Cañera grande, que comercializa el azúcar producida en esas 800 ha como una sociedad en relación directa con el ingenio, donde un porcentaje es destinado a inversión en tecnología e insumos y a acciones dentro de la comunidad, y el resto de la ganancia es distribuida entre los socios de acuerdo al porcentaje de hectáreas que aporta cada uno en la organización.

La Cooperativa tiene un fuerte trabajo social con la comunidad y las escuelas de la zona, donde se realizan donaciones y actividades recreativas. Además, desde hace dos años, cuenta con una radio propia a cargo del Sr. Luis "Lucho" González. La Radio "La Merced" no tiene un programa exclusivo de la Cooperativa, sino que está destinada para que cualquier persona de la comunidad pueda realizar un programa.

A pesar de constituirse como una empresa cañera grande por el número de hectáreas que tiene en total, la Cooperativa está formada por pequeños y medianos productores de la zona. Por lo tanto, desde su conformación la Mesa de Gestión tuvo la participación de su presidente, el Señor Mario Tizeira, en algunas de las reuniones. 


\section{Otros sujetos, otros relatos}

Algunas reuniones de la Mesa tuvieron la participación esporádica de sujetos que no llegaron a constituirse como actores de la organización, pero que expresaron su opinión sobre la problemática y propuestas sobre posibles estrategias y líneas de acción que se podían desarrollar. De este modo, hicieron sus aportes productores cañeros independientes, docentes, entre otros.

José Torres, agricultor de la Cooperativa Famaillá, en la primera reunión (21 de mayo de 2010) explicaba que la quema "es una costumbre ancestral y que, además de ser ancestral, es una necesidad. Llega un momento que la maloja es tal cantidad que hay que quemar. Es igual que si hacemos limpieza en una casa, hay un momento que hay que quemar algo de basura porque no la podemos transformar".

También sostenía que la implementación de la ley en el 2009 generó un mayor descontrol del fuego: "a mí me quemaron un lote. Cuando me fueron a decir que me estaban quemando yo les decía dejálo. Si yo me iba a ver el lote que se estaba quemado y caía la policía me metían preso porque había quemado, cuando yo era un damnificado. Esas son las cosas que ocurren. Hay gente que ha sido puesta presa".

Por su parte, el Ingeniero Agrónomo Ignacio Lobo Viaña, en la reunión del 9 de agosto de 2012 planteaba que era importante considerar los dos tipos de quema existentes: la quema como herramienta de producción y la quema que está metida en la cultura de la gente. "El otro tema es la quema que hace la gente. Los chicos que salen de la escuela van caminado y tiran un fosforito, queman un cañaveral. El grueso de las quemas de caña en pie son asî". También sostenía que hoy los pequeños productores que utilizan la cosecha semi-mecanizada no tienen alternativas para dejar de quemar: "el pequeño productor que tiene herramientas viejas no puede trabajar con esos equipos (se refiere a las cosechadoras integrales). Entonces, hasta que surjan alternativas para esos productores que eliminen la necesidad de quemar, lo van a seguir haciendo. No lo van a dejar de hacer".

Desde una posición bastante diferente a la mayoría de los productores del medio, el Dr. Carlos Chediack, médico de profesión y productor cañero de 50 has, no admite una erradicación progresiva de la quema ni excepciones para los pequeños productores. En la reunión del 9 de agosto de 2012 sostenía que la 
quema en general se debe eliminar urgente porque afecta la salud de la población y que el gobierno debe ofrecer las alternativas para que los productores y los ciudadanos puedan hacerlo. "Quemar es un delito, penado por la Nación. La quema no es limpiar, ni como era en la edad media, los que queman, no la caña, sino por todos lados es porque no tienen la posibilidad de que los asistan para levantar la basura. Hay un problema de educación y, fundamentalmente, hay una falta de decisión política de los gobiernos que han ido pasando. El gobierno si tiene decisión política puede colaborar con el productor chico, mediano para que trabaje y use la maloja como se usa en otros lados".

En cuanto a los problemas sobre la salud, Chediack planteaba lo siguiente: "si yo me pongo como médico en la posición de que la quema provoca y empeora patologías, yo no puedo permitir que se cumpla con ese delito. Esto merece una consideración real y sana que es legislar para que no se queme. Queremos que se termine con la quema, la población no tiene la culpa, los chicos de las villas que ya tienen bronquitis llenan los hospitales porque se agravan con la porquería de la contaminación. No tienen idea lo que es Tucumán en contaminación en la época de la zafra".

Lorena Casal, docente de la Comuna Rural El Naranjito (Cruz Alta), proponía apuntar a la difusión y concientización en la primera reunión de la Mesa (21 de mayo de 2010): "yo como docente y como una persona más del pueblo pienso que lo que hace falta es difusión y estaría buenísimo en las escuelas, en el CAPS ${ }^{39}$, en todo el pueblo informar, no sé, dar una pancarta, lo que sea, porque eso es lo que hace falta, difusión".

A partir de esta descripción de los actores que conforman la Mesa se visibiliza una heterogeneidad de instituciones que, con el aporte de sus miradas e intereses diversos, lograron construir una realidad de la quema y diseñar estrategias haciendo foco en los diferentes aspectos del problema. Al poner a dialogar estas diferencias, encuentros y contradicciones en el proceso se entrecruzaron, fusionaron y transformaron unos discursos con otros dando como resultado una mirada compartida para diseñar la transformación.

Para resumir de manera esquemática la visión de cada actor de La Mesa sobre la quema de caña de azúcar en Tucumán, manifestada en sus discursos,

${ }^{39}$ Se refiere a los Centros de Atención Primaria de la Salud (CAPS). 
realizamos el siguiente gráfico que muestra a cada uno con el sector al cual le adjudica la responsabilidad en la problemática abordada.
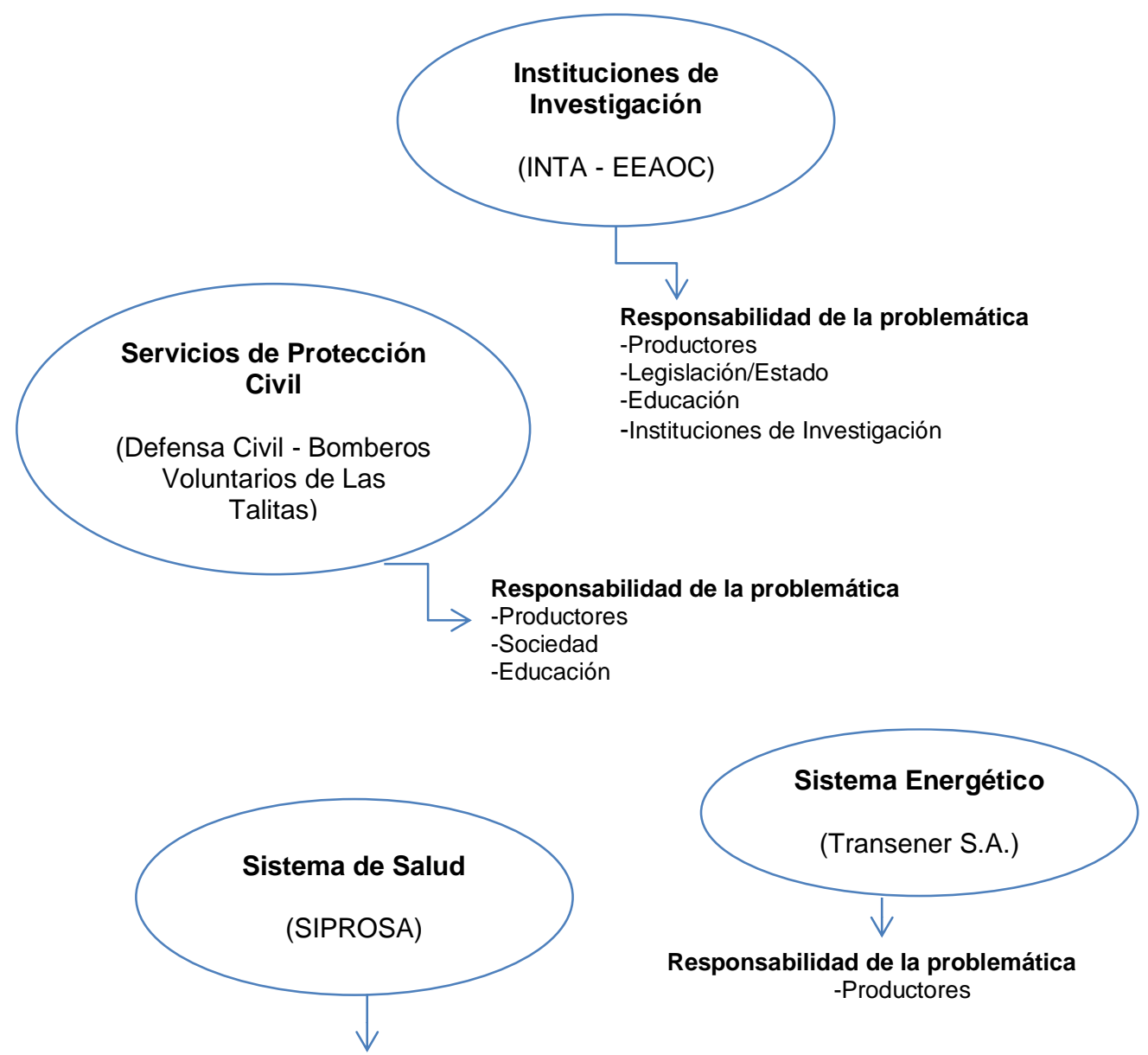

Responsabilidad de la problemática -Productores

Responsabilidad de la problemática -Medios de Comunicación
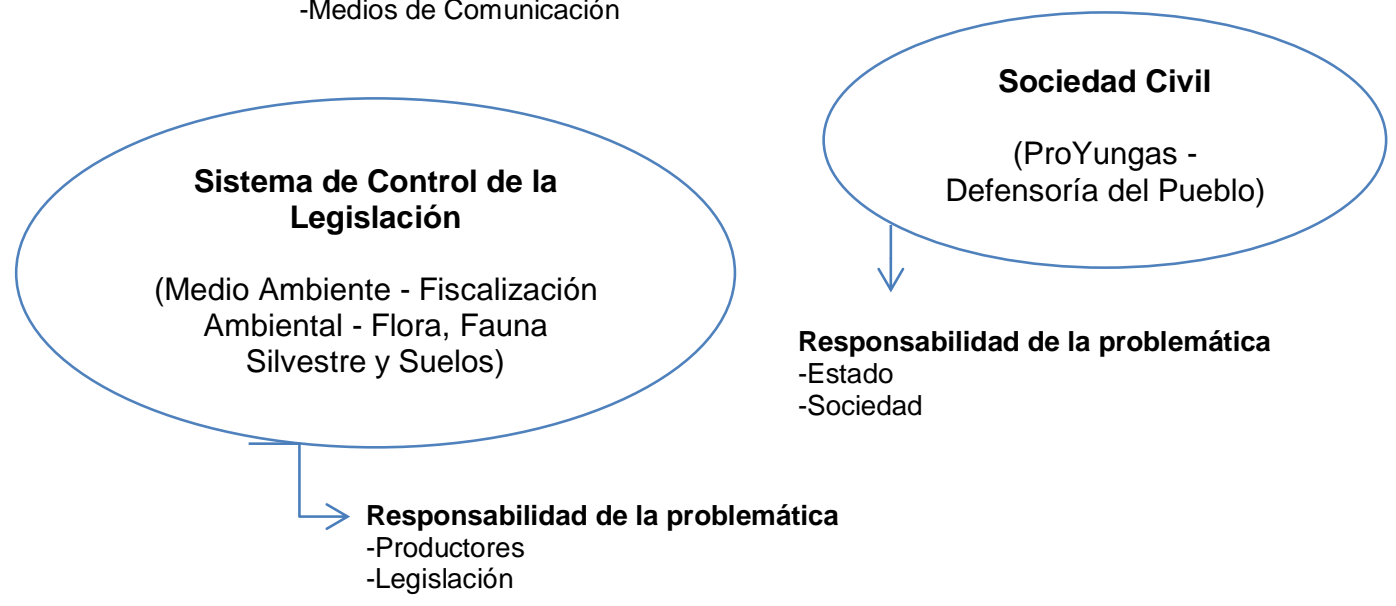

Responsabilidad de la problemática Estado Sociedad

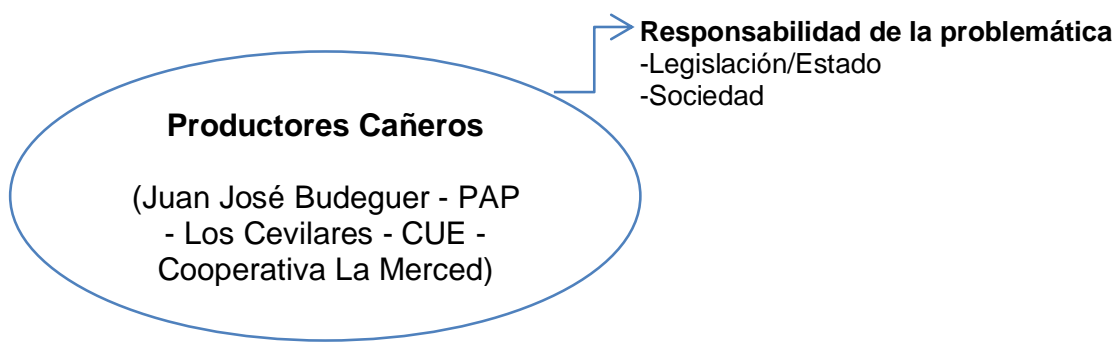


Como se visualiza en el gráfico, durante la construcción de la realidad sobre la problemática, una de las cuestiones centrales de la discusión fue la identificación del sector al cual se lo responsabilizaba de las quemas. De esta manera, los productores fueron considerados los principales responsables, señalados por la mayor parte de los actores. Le siguieron el Estado, la legislación y la sociedad, también identificados como tal por varios de los integrantes de la Mesa.

Además, entre los mismos actores se cruzaron culpabilidades. Mientras los productores acusaban a la legislación y al Estado, los organismos estatales como Medio Ambiente, Fiscalización Ambiental, Flora y Fauna y Defensa Civil los señalaban a ellos como los culpables.

Con estas opiniones se inició el diálogo entre los integrantes de la Mesa de Gestión Ambiental de Cruz Alta, en un camino que siguió construyéndose en medio de discusiones y transformaciones permanentes. 


\section{CAPÍTULO IV: PROCESOS COMUNICACIONALES DESARROLLADOS EN LA}

ORGANIZACIÓN

En el capítulo anterior decíamos que la Mesa de Gestión Ambiental de Cruz Alta, desde su conformación en mayo de 2010, llevó adelante un proceso de diagnóstico sobre la problemática de la quema de caña de azúcar en Tucumán y diseñó un programa para erradicarla, dentro del cual se elaboraron productos comunicacionales.

En este apartado nos proponemos describir y analizar comunicacionalmente ese proceso desarrollado por la organización desde una perspectiva teórica que entiende a la comunicación como relación social y cultural con sujetos que interactúan en prácticas socio-culturales donde intervenimos para planificar procesos de cambio. Lo comunicacional, entonces, trasciende los medios y las técnicas y se sitúa en la complejidad de las relaciones entre actores y sujetos, en el espacio de las prácticas sociales y las organizaciones donde se generan las producciones sociales de sentidos.

Desde esta perspectiva buscamos no sólo realizar un análisis de la realidad comunicacional de la Mesa, sino también construir un modo de intervención que tiene como fin último el cambio. Por ello, este análisis dará lugar, finalmente, a la construcción de las propuestas de cambio de la organización y sus prácticas junto a los actores en el siguiente apartado.

Entendemos esta mirada constructiva como un proceso en espiral, donde los procesos comunicacionales desarrollados por la organización, desde su constitución en el 2010, conformarán inherentemente una etapa de diagnóstico macro de la tesis. Esta espiral se comprende como un proceso de investigación complejo, que conlleva un análisis reflexivo donde inevitablemente encontraremos elementos y condiciones de las demás etapas de análisis, tanto de las ya desarrolladas cronológicamente en la organización como de aquellas que se llevan adelante en este proyecto de investigación.

Hablamos de realizar un diagnóstico comunicacional de la Mesa desde la perspectiva PLANGESCO, entendido como un proceso dinámico de construcción de conocimientos y propuestas para transformar la realidad de la organización y sus prácticas en el territorio. La actitud de diagnóstico supone "una mirada que le permite a los distintos actores establecer diferencias y regularidades, las 
características propias de cada situación, reconocer la trama compleja de las relaciones y la forma como los actores se constituyen comunicacionalmente en la misma desde una perspectiva histórica" (Uranga, 2008: 33).

La lectura de situaciones sociales desde lo comunicacional implica entender que nos encontramos allí mismo, en las prácticas, hábitos, dentro de ese espacio y tiempo, sirviéndonos de lo reflexivo. Lo que Daniel Prieto Castillo (2004: 97) expresa "la sociedad nos habla a través de múltiples discursos y nos va exigiendo que aprendamos a expresarnos de determinada manera y a referirnos a ciertos temas por encima de otros [...] una situación de comunicación comprende relaciones intrapersonales (yo conmigo mismo), grupales, sociales en general; las circunstancias económicas, políticas, culturales, el desarrollo de ciertas tecnologías, de ciertas formas de enfrentar y resolver los problemas de la naturaleza y la sociedad".

En este recorrido, construiremos la realidad comunicacional de la Mesa a partir del análisis de las situaciones de comunicación de la Organización en dos etapas:

En la primera, denominada "Propuesta de Programa de Erradicación Progresiva de la Quema de Caña de Azúcar en el Departamento", realizaremos un recorrido analítico del proceso de elaboración y ejecución de la propuesta en el territorio desde concepciones teóricas que nos permitirán construir las situaciones de comunicación.

En la siguiente etapa, "Productos comunicacionales elaborados por la Mesa", recorreremos el proceso de construcción y difusión de los afiches, spots publicitarios, el folleto, el volante, el video y los comunicados de prensa realizados por la organización.

Considerando que como comunicadora fui parte activa del proceso de desenvolvimiento de la Mesa, la principal herramienta metodológica para reflexionar, construir las relaciones y sistematizar el proceso desarrollado por los actores de la Mesa en las dos etapas de análisis será la observación participante.

"La presencia directa es, indudablemente, una valiosa ayuda para el conocimiento social porque evita algunas mediaciones -del incontrolado sentido común de terceros- ofreciendo a un observador crítico lo real en toda su complejidad, aunque inevitablemente siempre parcial. En esta línea, la observación participante es el medio ideal para realizar descubrimientos, para examinar 
críticamente los conceptos teóricos y para anclarlos en realidades concretas, poniendo en comunicación distintas reflexividades" (Guber, 2001: 57).

La metodología se complementará con otras técnicas como la recopilación documental de las actas y audios de las reuniones que quedaron registrados y los materiales elaborados; entrevistas semi-estructuradas a los actores de la Mesa; y análisis del discurso para analizar los relatos que aparecen en las diferentes situaciones de comunicación que abordaremos.

Es importante considerar que en los relatos los sujetos manifiestan la construcción que hacen de una realidad: su realidad. Verón y Sigal (1986: 126-127) señalan que "toda producción de sentido, en efecto, tiene una manifestación material" y que "partimos siempre de configuraciones de sentido identificadas sobre un soporte material (texto lingüístico, imagen, producción sonora, sistema cuyo soporte es el cuerpo, etc.) que son fragmentos de semiosis. Cualquiera que sea el soporte material, lo que llamamos un discurso o un conjunto discursivo no es otra cosa que una configuración espacio temporal de sentido".

En el mismo sentido, Samaja (2003: 31) plantea que "hay en la percepción, en el habla, en el pensamiento una inmensa cantidad de sujetos actuantes que aunque no sean reconocidos por nosotros cuando percibimos, hablamos o pensamos, sin embargo, están haciendo su trabajo: para nosotros, pero también en nosotros, por nosotros y para algún Otro, aunque no lo sepamos: es decir, para la Comunidad, el Estado y la Sociedad Civil".

Por esto, "de lo que se trata en los procesos llamados de comunicación, de información, culturales o como se quiera, es de la producción histórica-social de la significación y no de una mera reproducción. Significación que posee una materialidad histórica concreta y una forma no añadida, ni refleja, sino la que se produce desde una determinada racionalidad, la de la mercancía en nuestra sociedad que domina conformando tanto los objetos como los mensajes porque lo que codifica y domina son las relaciones sociales" (Barbero, 1987: 35).

\section{Etapa 1. Programa de erradicación de la quema}

Para lograr la eliminación gradual de la quema de caña en Cruz Alta, la Mesa construyó la "Propuesta de Programa de Erradicación Progresiva de la Quema de Caña de Azúcar en el Departamento" a través de un proceso complejo y dinámico 
que incluyó el diagnóstico sobre la problemática en Tucumán y el diseño y ejecución de dos planes.

El recorte temporal para describir y analizar la historicidad de este proceso serán los tres años de duración de la propuesta, desde que se creó en el 2010 hasta su finalización en el 2012.

El análisis comunicacional de esta práctica se guiará desde una concepción que entiende al diagnóstico, planificación y gestión de estrategias para la acción como tres momentos de un mismo proceso de conocimiento y de intervención y, por lo tanto, indisociables.

Esta perspectiva parte de pensar que el ideal de todo proyecto es construirse a partir de diferentes etapas: el diagnóstico dinámico, la planificación, el diseño de estrategias, la ejecución y la evaluación como fases que incluso, en diferentes momentos, pueden desarrollarse de manera simultánea y transversal.

En este sentido, tomamos la propuesta de Daniel Prieto Castillo (2000, citado por Uranga, 2001: 35) que rescata "el valor del esquema ya clásico (diagnósticoplanificación-gestión). Si coloco los guiones es porque aludo con ellos a una totalidad imposible (al menos idealmente) de fragmentar en acciones aisladas. Un diagnóstico sin consecuencias para la planificación carece de sentido, una planificación sin diagnóstico es pura improvisación y una gestión, sin los pasos anteriores, un camino orientado a resolverlo todo sobre la marcha, como si el día fuera suficiente para conocer y resolver situaciones complejas de más en más".

Desde que se conformó la Mesa de Gestión Ambiental de Cruz Alta, el primer desafío para los actores fue conocer la situación de la quema de caña en Tucumán a través de los actores y sus discursos vinculados a la problemática en el departamento Cruz Alta.

Durante las dos primeras reuniones, el 21 de mayo y el 8 de junio de 2010, se realizó un diagnóstico inicial para construir la realidad de la quema desde la visión y los intereses que perseguía cada actor. La metodología utilizada fue un debate dirigido por una moderadora, la ingeniera Cristina Biaggi del INTA, y la base de esa construcción fue el diálogo.

De acuerdo a la propuesta de Antonio Pascuali (2008: 62), entendemos que "sólo es, pues, auténtica comunicación la que se asienta en un esquema de 
relaciones simétricas, en una paridad de condiciones entre transmisor y receptor y en la posibilidad de oír uno a otro o prestarse oídos (Heidegger), como mutua voluntad de entenderse. Esta última es la condición básica e insuprimible de la nocontradicción en toda relación de comunicación (que llamamos diálogo)".

Los sujetos que participaron de este proceso fueron ingenieros agrónomos y una comunicadora del INTA, un agente sanitario representante del SIPROSA, productores cañeros medianos y grandes, un técnico de la Dirección de Defensa Civil, un técnico de la Dirección de Flora y Fauna Silvestre, una supervisora y una docente del nivel primario, un empleado comunal y un policía.

En ese recorrido de construcción de una realidad, los integrantes de la organización se fueron conociendo a partir de sus propias experiencias y relatos sobre el vínculo vivido con la quema de caña. Y, como vimos en la descripción de los actores en el capítulo anterior, esos relatos mostraron posiciones diferentes y contrapuestas, de acuerdo al rol y los intereses que perseguía cada uno. Como explica Samaja (2004: 37), "para Vico la experiencia es experiencia vital e histórica (o protagónica) en la que el sujeto se va construyendo a sí mismo mediante su obrar". De este modo, cada actor aportó desde esa especificidad a la definición de la problemática.

Sandra Massoni (2007: 31) entiende que "es en las relaciones donde sujetos, prácticas e imaginarios se reinventan; y es a partir de las relaciones que se fijan posiciones de diferencia, siempre inestables pero no aleatorias, entre actores sociales. La mediación es un espacio de articulación, no un espacio mediador. No hay extremos entre los cuales mediar; hay relaciones entre matrices que configuran posiciones de sujetos".

Por esto, es importante reconocer que el conflicto es dinamizador del cambio, ya que las prácticas y procesos sociales se refieren "a situaciones con alto nivel de inestabilidad y de conflictividad, con actores que ponen en juego su libertad, que luchan por el poder así no lo formulen de esa manera, y que buscan incidir en bien de sus propios objetivos" (Uranga, 2008: 2).

Si bien la Mesa no cuenta con un documento donde se encuentre registrado este diagnóstico, mediante la revisión de las actas y audios de las reuniones identificamos las condiciones de la problemática aportadas por los actores. La importancia de exponerlas radica en facilitar la comprensión de la realidad construida por los mismos, que sirvió como disparadora de las estrategias que se 
diseñaron posteriormente. Por esto, realizaremos una sistematización de las ideas aportadas por los sujetos, registrando las matrices comunes para reunirlas en los siguientes ejes: de carácter político, legal, social-ambiental, económico-tecnológico y comunicacional.

Este registro diferenciado nos permitirá identificar las distintas dimensiones que constituyen el problema de la quema de caña, dentro de las cuales se enmarcan diferentes condiciones vinculadas entre sí y, por lo tanto, indisociables para entenderlo y construir transformaciones.

La dimensión política hace referencia a cuestiones vinculadas al Estado provincial; la legal, a las leyes y decretos reglamentarios que prohíben la quema de caña en la provincia y el país; la social-ambiental, a la relación de las quemas con la sociedad civil, la convivencia con el medioambiente, la salud; la económicotecnológico, a las cuestiones referidas al ciclo del cultivo (plantación, cosecha y pos cosecha); y la comunicacional, a la difusión de información en medios de comunicación locales, a la educación y capacitación y a los espacios de encuentro para auspiciar diferentes diálogos.

Como veremos más adelante, la Mesa sólo logró trabajar sobre algunas de estas condiciones, especialmente las de carácter legal, social-ambiental y comunicacional, considerando que eran aquellas en las que podía intervenir.

\section{Condiciones:}

De carácter político

- Falta de recursos humanos para que la Dirección de Fiscalización Ambiental levante las actas ante el incumplimiento de la ley provincial.

- Los recursos provinciales para actuar en contra del fuego son limitados e inadecuados para ingresar a los lotes cañeros.

\section{De carácter legal}

- Incumplimiento del Decreto N 795/3 con la excepción de quema controlada para los productores minifundistas menores de 50 hectáreas. 
- Se debe legislar de manera diferenciada los dos tipos de quema como herramienta de producción: la quema de caña en la cosecha semi-mecanizada y la quema de maloja después de la cosecha en el sistema mecanizado integral.

- La legislación no contempla la situación de los medianos y grandes productores que por problemas de superficie deben utilizar la cosecha semi-mecánica y quemar caña.

- Ambigüedad y falta de flexibilidad en la legislación provincial que prohíbe la quema de cañaverales en la provincia.

- Los productores no permanecen en el lugar del fuego por medio a ser apresados.

\section{De carácter social-ambiental}

- A la quema de los productores se suma la quema generalizada en la sociedad tucumana para la limpieza de banquinas, residuos domiciliarios o basurales de comunas rurales.

- Existe una condena social hacia los productores cómo únicos responsables de las quemas.

- La quema contamina el medioambiente y genera problemas en la salud de la población.

\section{De carácter económico-tecnológico}

- Los productores utilizan la quema por una cuestión económica para abaratar los costos de producción.

- Falta de alternativas tecnológicas para que los productores eviten la quema de caña en el sistema semi-mecánico y la quema de maloja en el sistema mecanizado integral.

- En la mayor parte de los productores hay una falta de acceso a la tecnología que permite dejar de quemar.

- Los productores son víctimas de quemas accidentales o intencionales por parte de personas ajenas a las explotaciones cañeras.

- El productor es la persona más preparada para apagar un incendio de cañaverales. 
- Las empresas concesionarias de energía se ven afectadas por los cortes de servicio a causa de la quema de cañaverales.

\section{De carácter comunicacional}

- Falta de campañas de difusión/comunicación para la prevención de la quema de cañaverales.

- Falta de programas de educación sobre la quema de caña.

- Inadecuada circulación de información sobre la problemática en los medios de comunicación.

Ante este escenario construido por los mismos actores de la organización, éstos reconocieron que se trataba de una problemática compleja, donde se debía trabajar tanto con los productores cañeros como con la sociedad en general. Y a la hora de diseñar las estrategias se debía diferenciar la situación de los productores medianos y grandes y la de los más pequeños (menos de 50 ha), que aún no disponen de la tecnología adecuada para dejar de quemar la caña. También, distinguir los dos tipos de quema en el proceso de producción: la quema de caña durante la cosecha semi-mecanizada y la quema de los residuos agrícolas de cosecha (maloja) en la post-cosecha. Por último, se debía tener en cuenta la legislación nacional y provincial vigente.

Desde una concepción de la comunicación como proceso complejo, dinámico y democrático, visualizamos una construcción participativa de la realidad sobre la quema en el diagnóstico realizado por la Mesa a partir de un diálogo basado en la multiplicidad de voces de los actores.

En este sentido, se destaca la característica de construcción colectiva que se asume en un diagnóstico, que intenta colocarse por encima de la individualidad "para adentrarse en la búsqueda de la acción común de los actores sociales, incorporando también los intereses materiales, las concepciones y las percepciones de los colectivos" (Uranga 2008: 4).

Con este diagnóstico inicial, en la tercera reunión realizada el 16 de junio de 2010 se comenzaron a pensar las estrategias de transformación y se decidió 
elaborar la "Propuesta de Programa de Erradicación Progresiva de la Quema de Caña de Azúcar en el Departamento".

El proceso de diseño de las estrategias también se realizó con el aporte de todos los integrantes de la Mesa. La metodología empleada fue un taller participativo, donde se dividió a los actores en dos grupos, considerando que se trabajaría con un plan destinado a los productores cañeros y otro a la sociedad civil con un enfoque integral del problema.

El grupo 1 trabajó sobre la propuesta para los productores, donde participaron los ingenieros agrónomos del INTA, los productores cañeros y los técnicos de las Direcciones de Defensa Civil y Flora y Fauna Silvestre de la Provincia. El grupo 2 lo hizo con el plan para la sociedad civil, con el aporte de los técnicos del Pro Huerta, la comunicadora del INTA, el agente sanitario y una docente del nivel primario.

Esta división respondió a la necesidad de considerar los conocimientos, saberes disciplinares que podía tener cada actor para aportar a la construcción de cada una de las estrategias en función de su historia, formación académica u oficio profesional. Claudia Villamayor (2002: 8) explica:

Si la percepción es algo que se va desarrollando a modo de proceso de aprendizaje, la experiencia previa condiciona las posteriores, sin que ello signifique necesariamente que el mismo individuo haya vivido personalmente todas esas experiencias. Hay un aprendizaje cultural que se apoya en experiencias sustitutas que se verifican en los grupos, los medios masivos de comunicación, en las redes de relaciones. La vida cotidiana es el lugar de las interacciones: el sujeto en su historia, en su contexto, en un tiempo y en permanente relación. Las experiencias que se viven en los grupos constituyen, sin embargo, la matriz social del individuo donde se construye el repertorio de significados que condicionan las formas y los modos de enfrentarse a situaciones diferentes de las habituales.

La sistematización de la información surgida del taller y la redacción del documento estuvieron a cargo de los técnicos del INTA. Luego, el texto fue discutido en una reunión con el resto de los integrantes de la Mesa donde todos realizaron sus aportes. 
Finalmente, la Propuesta de Programa de Erradicación Progresiva de la Quema de Caña de Azúcar en el Departamento Cruz Alta fue aprobada por los actores y comenzó a implementarse ese mismo año. Ellos la definían de la siguiente manera: "Se entiende que este programa puede constituir una experiencia piloto de articulación institucional y autogestión local, que luego podría servir de orientación para la aplicación en el resto de la provincia".

En la Justificación del documento no se profundizó en el diagnóstico realizado por la Mesa. Éste se expone de manera muy resumida, sin plantear algunos de los puntos más relevantes que salieron en el diagnóstico inicial y que son importantes para comprender la problemática y explicar las estrategias que se planificaron posteriormente. Esto puede deberse a la falta de sistematización del mismo que mencionamos al inicio del apartado.

Con esto nos referimos a que no rescata los motivos por los que los productores utilizan la quema. Tampoco menciona la falta de alternativas tecnológicas o de acceso a la tecnología que permite dejar de quemar. Otro de los puntos centrales que no aparece es la falta de campañas de difusión/comunicación y de programas de educación para la prevención de la quema de cañaverales ni la falta de información sobre la problemática en los medios de comunicación. Todas estas demandas, como veremos más adelante, son las que dieron origen a las estrategias que se diseñaron para lograr la erradicación de la quema.

En este sentido, consideramos que la planificación de una estrategia siempre debe fundamentarse en la situación detectada en el diagnóstico para explicar las razones por las cuales ese proyecto es una respuesta adecuada a las necesidades. Es decir, explicitar desde dónde se parte para entender hacia dónde se quiere llegar. Como explica Gloria Pérez Serrano (1993, citado por Uranga, 2001: 34), "la planificación nos ayuda a conjugar la utopía con la realidad, a armonizar lo que es y lo que debiera ser, a analizar dónde estamos y hacia lo que se tiende".

Siguiendo nuestro recorrido analítico, en el Marco legal considerado el programa mencionaba que "pretende cumplir con los objetivos de la legislación actual, facilitando la aplicación de las medidas necesarias". Y hacía referencia a los elementos legales que se consideraron para la elaboración de la propuesta: Ley Provincial № 6253/2009, Ley Provincial № 7459/2004 y su Decreto reglamentario 795/3-2005 (Modificado por Decreto no 2523/9-2008), Ley Provincial Nº 7.873/2007 y su Decreto reglamentario № 3695/3/2007, Ley Nacional 26.562/09 y Ley 6.292/92. 
Con respecto a la Duración y metas, el programa proponía un plazo de tres años con evaluaciones anuales de resultados que se medirían en número de focos de incendio; número de productores participantes del programa; superficie cañera participante en el programa; acciones de concientización; número de escuelas y alumnos participantes en el programa. El documento expresaba que "se establecerán metas para cada indicador", que finalmente no fueron definidas. Y si bien se lograron determinar algunos de estos resultados, no fueron evaluados por los actores ni sistematizados en un documento.

Del mismo modo, se comprometía a escribir informes anuales, que no llegaron a elaborarse; además de realizar un monitoreo mensual de focos de incendio en la temporada de fuegos, lo cual sí llegó a cumplirse porque formaba parte de las actividades del Laboratorio de Sistema de Información Territorial del INTA Famaillá.

En esta descripción se reconoce que la Mesa tuvo la intención, aunque no llegó a concretarlo, de llevar adelante lo que se denomina evaluación del proceso o evaluación continua. Es aquella que "se realiza durante la ejecución de las acciones previstas en la planificación, sirve para detectar las dificultades que se dan durante la ejecución de las actividades e introducir los mecanismos de corrección. Este tipo de evaluación le brinda al equipo de trabajo información permanente para adecuar los proyectos y sus actividades, y por esta misma razón es recomendable que los responsables de la ejecución de las acciones participen de la evaluación" (Villamayor, 2002: 80).

En cuanto al Desarrollo de la propuesta, el documento pretendía "cumplir con los objetivos de la legislación actual, facilitando la aplicación de las medidas necesarias". Y, basándose en las demandas surgidas en el diagnóstico, exponía un plan dirigido a los productores cañeros, por un lado, y un plan destinado a la sociedad en general del departamento Cruz Alta, por otro.

De acuerdo a la terminología clásica de la planificación, el concepto de "plan" refiere al término de carácter más general de la programación, que engloba programas y proyectos. De este modo, consideramos que el término adecuado para denominar estas propuestas hubiese sido el de "proyectos", que son aquellos que comprenden una serie de actividades concretas.

A continuación, analizaremos el proceso de diseño y ejecución en el territorio de ambos planes, a partir del reconocimiento de las etapas necesarias para 
planificar y gestionar un proyecto: el diagnóstico, la planificación propiamente dicha, el diseño de estrategias, la ejecución y la evaluación.

\section{Plan destinado a los productores cañeros}

En el documento, el programa proponía un plan destinado a los productores para "avanzar hacia un ordenamiento, primero; una reducción en el uso y aplicación del fuego en los cultivos de caña de azúcar, después; y finalmente, cumplir con la erradicación definitiva antes del 2024 en el territorio departamental de acuerdo a las excepciones de la legislación vigente" ${ }^{\prime 40}$.

Para lograr este objetivo, planteaba como necesaria la instrumentación de dos protocolos o directrices con los pasos a seguir según se tratara de incendios o aplicación de fuego controlado ${ }^{41}$, definiendo los roles de cada actor de la Mesa. Además, definía normas de precaución a tener en cuenta para evitar las quemas accidentales.

Las "Directrices generales para realizar quema controlada de cañaverales provenientes de cosecha manual y/o semi-mecanizada" contemplaban un régimen de uso controlado del fuego para los productores minifundistas menores de 50 hectáreas cuyos lotes se encuentren ubicados en Cruz Alta, dentro de un plan de reducción progresiva.

Las "Directrices generales para aviso de incendios de vegetación" indicaban los pasos a seguir en caso de incendios accidentales o generados intencionalmente por acción de terceros.

Por último, las "Normas de precaución y resguardo para evitar la quema de cañaverales provenientes de la cosecha integral de caña de azúcar" explicaban las medidas que debía tomar el productor para prevenir quemas accidentales en sus cañaverales.

En la descripción del plan no se explicita una programación que permita llevar adelante esta propuesta, en la cual se definan las características de los

\footnotetext{
${ }^{40}$ Se refiere a las excepciones contempladas para los pequeños productores (menos de 50 ha) en el Decreto $N^{\circ} 795 / 3-2005$ reglamentario de la Ley $N^{\circ} 7459$.

${ }^{41}$ El plan distingue lo que es un incendio de una quema controlada. Un incendio es todo aquel fuego que se produce de manera espontánea, accidental o no, bajo cualquier condición, sin conducción y que causa daños severos en la vegetación, suelo, infraestructuras, pérdidas económicas y, en los peores casos, muerte. La quema controlada es la aplicación de fuego sobre una determinada vegetación en condiciones de humedad del suelo, de los combustibles, de la temperatura ambiente y vientos óptimos, de modo que permita su confinamiento a un área determinada y que responda a objetivos definidos y autorizados previamente.
} 
interlocutores (los productores cañeros de menos de $50 \mathrm{ha}$ ); las modalidades de ejecución; las actividades que generarán los resultados esperados; los recursos económicos, humanos y materiales necesarios para llevarlo adelante; ni un sistema de evaluación.

La definición clara de estos criterios es esencial para hacer viable y factible la planificación en un proyecto y evitar la improvisación de las acciones. En este sentido, consideramos que "la planificación puede ser entendida y utilizada por los actores con voluntad de cambio como una herramienta eficaz para armonizar propósitos que se apoyen en objetivos políticos y sociales de transformación, tomando en cuenta todos los elementos del escenario en el que los mismos deben concretarse y desarrollando la manera de implementarlos de manera eficaz para generar alternativas positivas" (Uranga, 2001: 34).

En el año 2011, la Mesa elaboró una herramienta para instrumentar las directrices y normas descriptas en el plan: el "Compromiso de adhesión voluntaria al programa piloto de erradicación de la quema de caña de azúcar en el departamento Cruz Alta, Tucumán" destinado a los pequeños productores cañeros. Al firmar el documento, éstos podían solicitar la excepción de quema controlada, comprometiéndose a cumplir con los pasos mencionados en las directrices y normas. (Anexo 1)

Para la puesta en marcha del compromiso, se presentaban dos desafíos: lograr que los productores conozcan y firmen el documento y, por otro lado, conseguir que la Dirección de Fiscalización Ambiental dependiente de la Secretaría de Medio Ambiente de la Provincia de Tucumán como autoridad competente ${ }^{42}$ los apruebe para evitar que los productores firmantes puedan ser sancionados.

Mientras los integrantes de la Mesa realizaban gestiones con los funcionarios de la Secretaría para conseguir la aprobación, se inició la difusión del documento entre los productores de Cruz Alta. Para ello, se utilizaron diferentes herramientas como un comunicado de prensa enviado por la Mesa a los medios de la provincia y entrevistas en algunas radios comunitarias de Los Ralos, contando de qué se trataba, el objetivo que tenía, a quiénes estaba destinado y dónde podían inscribirse los interesados. Finalmente, se lograron muy pocos compromisos firmados. Los

\footnotetext{
42 La función de este organismo del Estado en relación a la legislación que prohíbe la quema de caña está descripta en la página 69 de la tesis.
} 
integrantes de la Mesa reconocieron que esto se debió a que las herramientas de difusión fueron insuficientes o inadecuadas.

Esto deja expuesta la falta de un diagnóstico de los medios de comunicación que permitiera planificar una estrategia acorde a los resultados deseados. Esto posibilita la identificación de los espacios mediáticos potenciales para la difusión del compromiso dentro del contexto de influencia de la organización, además del reconocimiento de aquellos medios más significativos para el público objetivo: los productores.

Continuando la difusión del compromiso, en el año 2012, la ingeniera Cristina Biaggi del INTA le comentó la propuesta al Sr. José Reviglione, presidente de la Cooperativa El Porvenir, quien se comprometió a conseguir que los integrantes de su organización firmaran el documento. De este modo, se lograron 100 compromisos firmados que fueron remitidos a la Dirección de Fiscalización Ambiental.

En esta concepción de priorización de la difusión del compromiso en los medios o a través de intermediarios se reconoce la preponderancia de la dimensión informativo instrumental de la comunicación, basada en la transmisión de "información" (el compromiso) de un "emisor" (la Mesa) a un "receptor" (los productores cañeros).

Los beneficios de esta racionalidad comunicacional son la posibilidad de organizar la información que desea transmitir la organización de acuerdo a sus intereses y elegir la manera más adecuada para hacerlo, sin considerar las repercusiones, ni dar lugar a espacios de intercambio con los interlocutores.

Sin embargo, los límites de este enfoque están en el no reconocimiento de las relaciones existentes en los procesos de construcción de consensos o de decisión entre los actores, es decir, en los espacios de producción de sentidos, que no operan según una racionalidad lineal.

Así, con esta estrategia, la Mesa no consideró espacios de encuentro con los productores no participantes de la Organización que posibiliten el intercambio de reflexiones y la construcción en común sobre la problemática de la quema de caña de azúcar. En este sentido, compartimos la propuesta de la Perspectiva de la Comunicación para el Cambio Social que "rechaza el modelo lineal de la transmisión de información desde un emisor central a un receptor individual y, en cambio, 
fomenta un proceso cíclico de interacciones centradas en el conocimiento compartido y la acción colectiva" (Gumucio Dragón y Tufte, 2008: 24).

Finalmente, el Secretario de Medio Ambiente de la Provincia, Ing. Alfredo Montalván, dijo que no podía autorizar los documentos porque no había conseguido la autorización de sus superiores. De este modo, el compromiso como estrategia fracasó. En la reunión de la Mesa con la Comisión de Medioambiente de la Legislatura de Tucumán (3 de agosto de 2012), el funcionario lo explicaba así: "ahora estamos ahí entrampados porque el pequeño productor no tiene más remedido que la semi-mecanizada. Puede hacer la quema desde un punto de vista controlado y desde lo técnico bien direccional. La Mesa de Gestión avanzó en eso, pero yo no los puedo seguir acompañando porque no tengo soporte administrativo y jurídico. Es complicado porque yo no puedo poner el gancho y decir 'señores está autorizada la quema controlada' porque no existe eso. La ley en ese aspecto es bastante ambigua, autoriza pero no autoriza. Si yo estuviese autorizando una quema controlada estaría chocando contra la normas y al mismo tiempo con una complicación desde el punto de vista penal muy compleja".

En el relato del funcionario se manifiesta un reconocimiento de los límites tecnológico-productivos y legales que rodean a la problemática de la quema y que fueron identificados en el diagnóstico inicial realizado por la Mesa. Además, se destaca la propuesta de quema controlada de la organización como una alternativa. De allí tal vez podamos comprender la decisión de la Secretaría de Medio Ambiente de integrarse a la Mesa en el año 2011.

Sin embargo, el límite para aprobar el compromiso se basa en la falta de "soporte administrativo y jurídico" a la cual alude el secretario en referencia a la legislación provincial y nacional, pero también a una decisión política del Estado Provincial en relación a la problemática.

\section{Plan destinado a la sociedad civil}

Para trabajar con la sociedad, la Propuesta de Programa de Erradicación Progresiva de la Quema de Caña de Azúcar en el Departamento Cruz Alta proponía un plan para abordar los aspectos sociales y culturales de la quema en general, buscando reducir al mínimo los incendios y quemas accidentales.

Como objetivo señalaba "facilitar el diálogo entre los diferentes actores del territorio para la articulación productiva de sus saberes y capacidades en función de 
la construcción de consensos de transformación en relación a la problemática de la quema en Tucumán. Se buscará ofrecer los instrumentos para garantizar más y mejores espacios de participación y construcción entre los actores, fortaleciendo acciones conjuntas entre las instituciones y los grupos ciudadanos, para diseñar $e$ implementar una campaña de comunicación que involucre a todos los sectores y considere la sostenibilidad ambiental para garantizar una mejor calidad de vida".

Este punto hace referencia al rol del comunicador como facilitador del diálogo entre la Mesa y sus interlocutores para promover la construcción en común de los conocimientos sobre la problemática y las estrategias de cambio. Los conceptos utilizados fueron tomados de la perspectiva de la comunicación para el cambio social que propone "trabajar con la comunidad y no para ella, promoviendo y potenciando los elementos transformadores que permitan un grado aceptable de desarrollo sostenible en la población. Es la base del diálogo la que posibilita la participación ciudadana en la construcción de su vida cotidiana y de su futuro" (Díaz Larrañaga, 2009: 11).

Como veremos más adelante, en el funcionamiento de esta propuesta, la Mesa logró involucrar la participación de los ciudadanos por momentos, mientras en otros trabajó desde paradigmas de la comunicación basados en el diseño de tecnologías para persuadir en lugar de educar.

Para lograr el objetivo, el plan describía dos estrategias a desarrollarse de manera simultánea y complementaria: una campaña de concientización y la mediación pedagógica en las escuelas del área en cuestión.

\section{En cuanto a la "Campaña de concientización sobre la problemática de la} quema", se proponía trabajar en la planificación de una campaña de sensibilización/concientización sobre la quema en general, a fin de instalar el tema en la sociedad local y movilizar la reflexión de la población, procurando un cambio de actitud. Se menciona al público objetivo como "sociedad local" y "población", sin especificar quiénes son, sus características y relaciones.

La definición de este objetivo se sitúa en el modelo positivista emisormensaje-receptor, basado en la trasmisión de información, y en un concepto que predominó en la década del 60' y aún persiste en la actualidad en el cual "a través de la comunicación se piensa en convencer y enseñar para modificar valores y actitudes" (Saintout, 1998: 24). Como explica Rosa María Alfaro (2006: 89), "lo que 
se cuestiona en este modelo no es sólo su verticalidad sino su dureza formal al pensar la comunicación como una flecha que se dirige al receptor y va en una línea de transformación pues ese es el deseo del señor emisor. La interactividad y el diálogo no cuentan".

Siguiendo esta idea de instrumentalidad de la comunicación, en la estrategia se planteaba como única actividad la realización de productos mediáticos para la difusión de información, detallando los pasos a seguir por los actores de la Mesa para hacerlo:

1. Definir los aspectos de la problemática a comunicar;

2. Discutir las herramientas a utilizar;

3. Diseñar el mensaje adecuado para cada una.

Para llevar adelante el segundo punto, bajo la denominación de "ejemplos serían" la estrategia describía una serie de herramientas que podrían ser consideradas por los actores al momento de la elección. Sólo se las menciona, sin analizar las características, funciones, modalidades de uso, ni la articulación con los destinatarios de cada una.

- Campaña gráfica en la vía pública: Colocar carteles publicitarios gigantes en las rutas provinciales. Diseño de 3 (tres) modelos de afiches y 1 (uno) modelo de volante o folleto resumen.

- Campaña publicitaria en medios televisivos: Spots publicitarios para los diferentes medios públicos.

- Campaña publicitaria en medios radiales: 2 (dos) frases radiales para ser difundidas en radios de alcance departamental.

- Publicaciones en los medios de comunicación locales: convenir publicaciones de recomendaciones en distintos programas televisivos y medios escritos (revistas y diarios), a fin de mantener vigente la temática y profundizar la campaña. 
Por último, en el documento no se explicitaban las metas, actividades y recursos necesarios para ejecutar los productos ni un sistema de evaluación para realizar un seguimiento de su implementación. En este sentido, se considera fundamental la definición de una planificación para dar coherencia y continuidad a la selección, producción, contenidos y ejecución de los materiales elaborados.

La campaña de concientización se inició ese mismo año (2010). Los actores de la Mesa optaron por algunas de las herramientas sugeridas en el documento y elaboraron una serie de productos, cuyo análisis sobre el proceso de creación y difusión de cada uno profundizaremos en el próximo apartado del capítulo.

De este modo, se creó un afiche destinado a los productores con recomendaciones para evitar las quemas, que fue ubicado en la puerta de los cuatro ingenios del Este de la Provincia (Concepción, Cruz Alta, La Florida y San Juan). Además, se realizaron dos afiches dirigidos a la sociedad con las frases "Quemar nos hace mal a todos" y "Prender fuego no es un juego", que fueron colocados en algunas escuelas, hospitales y comisarias del departamento Cruz Alta. (Anexo 2)

Otra de las herramientas utilizadas fue el comunicado de prensa para dar a conocer la propuesta de la Mesa de Gestión Ambiental de Cruz Alta y su visión sobre la complejidad de la problemática. Entre el 2010, 2011 y 2012 se difundieron seis notas entre los medios que forman parte de la agenda del INTA Famaillá.

Finalmente, durante el 2012 se diseñó un spot televisivo y radial de prevención de la quema para ser difundido en los medios de comunicación de toda la Provincia, que no llegó a publicarse (Anexo 3); además de un volante que se distribuyó en 97 escuelas y lugares públicos (comisarías, hospitales) del área de influencia de la campaña. (Anexo 4)

La segunda estrategia dentro del plan destinado a la sociedad, denominada “Mediación pedagógica en las escuelas", proponía diseñar un proceso estratégico de comunicación para trabajar con los alumnos y docentes de las escuelas de Cruz Alta sobre la problemática de la quema.

El plan mencionaba estar basado en la propuesta de la mediación pedagógica de Gutiérrez Pérez y Prieto Castillo, citando la definición de los autores: "Se busca abrir el camino a nuevas relaciones del estudiante: con los materiales, con el propio contexto, con otros textos, con sus compañeros de aprendizaje, incluido el docente, consigo mismo y con su futuro. Se insiste en la importancia del interlocutor como verdadero agente de la búsqueda y construcción del sentido. Se 
trata de pasar de una modalidad anclada en la enseñanza y en objetivos preestablecidos a otra caracterizada por el aprendizaje, la participación y la construcción de conocimientos".

Desde esta argumentación, el documento expresaba como objetivo que "los alumnos y docentes, desde el lugar que ocupan en el acto educativo, puedan actuar como mediadores pedagógicos y como personas que aprenden con todo el apoyo de la pedagogía. La idea es que puedan construir, junto a los educadores, los conocimientos sobre la problemática de la quema, a partir de la creatividad, los materiales didácticos y el intercambio de experiencias entre ellos".

Por último, en cuanto a las actividades a desarrollar para alcanzar este objetivo, la estrategia señalaba que la Mesa diseñaría las prácticas pedagógicas, es decir los procedimientos más adecuados a emplear para facilitar la construcción en común de los conocimientos sobre la quema. Sin embargo, no explicitaba una programación para llevar adelante la propuesta, que defina características de los interlocutores (alumnos y docentes), modalidades de ejecución, actividades, recursos necesarios y un sistema de evaluación.

En esa búsqueda de las prácticas pedagógicas a utilizar, en el mes de agosto de 2010, los integrantes de la Mesa decidieron realizar una experiencia piloto en 4 escuelas de la localidad de Los Ralos (Bríjido Terán, José Ingenieros, Eudoro Avellaneda y Colonia Lolita), que era la zona de influencia del agente sanitario integrante de la Mesa.

La metodología utilizada fueron talleres participativos, considerados como "espacios creados donde se reúnen actores involucrados en algún proceso específico, auspiciando reflexiones en búsqueda de la multiplicidad de voces y la toma de decisiones en compromiso común. La participación significa que cada uno de los actores de su voz, teniendo el derecho de ser escuchado y también la voluntad de escuchar a los demás; pero también de aceptar diferencias, con las cuales lograr construir un "trabajar con" en cada una de las propuestas a desarrollar" (Buschiazzo, 2009: 86).

De este modo, se decidió trabajar con el último curso del nivel primario, niños de 11 a 13 años, en cada escuela mediante dos actividades. En la primera, los representantes de la organización debatieron y construyeron los conceptos de la quema en general junto a los alumnos y docentes mediante la técnica de "lluvia de ideas", teniendo en cuenta sus conocimientos previos y las experiencias de la vida 
cotidiana local. En la segunda, ante la consulta sobre cómo se podía informar sobre el tema a la comunidad, en las cuatro escuelas los chicos hicieron propuestas similares como la realización de maquetas, murales, afiches y volantes para pegar en distintos lugares del barrio y de unas frases para difundir en las radios locales. La idea de los niños generó la tercera actividad de la jornada, donde los representantes de la Mesa acompañaron el proceso de producción de esos materiales.

Como cierre de la experiencia piloto, el 6 de octubre de 2010 se realizó el "Encuentro Prender Fuego no es un Juego", con el objetivo de exponer los productos elaborados por los 200 alumnos y docentes de las cuatro escuelas participantes.

Después de la apertura del evento, los integrantes de la Mesa de Gestión hicieron un recorrido para ver las producciones de los chicos que fueron colocadas en las paredes laterales del salón con un cartel indicativo de la escuela a la que pertenecían.

Al finalizar la jornada, se invitó a los niños a convertirse en educadores de su comunidad para evitar las quemas y proteger el medioambiente, y se les entregó un certificado, una gorra y una calcomanía que acreditaba su pertenencia a la "BRIGADA ECOLÓGICA" de la ciudad. En ese momento, los alumnos y docentes se comprometieron a ubicar sus producciones en distintos lugares públicos de su barrio.

En el análisis de esta experiencia, partiendo de una concepción de la comunicación-educación que concibe a la enseñanza como una construcción en común y no como la transmisión de saberes de un sujeto a otro, podemos reconocer que la Mesa pudo situarse en la presencia del alumno como un ser sociocultural, histórico, atravesado por la complejidad de la interacción con el entorno y con los otros sujetos y, por lo tanto, con capacidad para construir conocimientos y realizar productos para informar a su comunidad.

En este sentido reflexiona Francisco Gutiérrez Pérez al considerar que las exigencias básicas de una pedagogía participada son las estructuras móviles y comunicación a nivel de bases. "Unas estructuras que permitan el máximo número de contactos y experiencias con la vida [...] Imposible lograr la participación de las bases (los alumnos) en el proceso de aprendizaje si no se llega a obtener una comunicación horizontal, prerrequisito de la comunicación dialógica. Este tipo de comunicación implica admitir que el profesor ya no es un sabelotodo sino un 
coinvestigador, coaprendiz y corresponsable en la acción educativa [...] Las aportaciones de todos los participantes puestas en común son el verdadero enriquecimiento del grupo" (Gutiérrez Pérez, 2008: 122).

Después de considerar como exitosa esta experiencia piloto a partir de lo vivenciado en el Encuentro prender fuego no es un juego, los actores de la Mesa quisieron ampliar la propuesta al resto de las localidades del departamento Cruz Alta en el año 2011. Pero, la mayor limitante era conseguir los recursos humanos que cumplieran el rol de facilitadores del intercambio en las escuelas.

A partir de allí, el Sr. Ariel Leiva propuso diseñar un proyecto para trabajar con los agentes sanitarios del Área Programática Este del SIPROSA como capacitadores. Recordemos que, de acuerdo a su estructura de funcionamiento, el SIPROSA se divide en 4 Áreas Programáticas: Sur, Centro, Oeste y Este. Esta última tiene un supervisor de agentes sanitarios, del cual dependen 13 supervisores de áreas operativas que tienen a su cargo a unos 290 agentes de terreno en total.

Después de una reunión con la Dra. Irma Díaz, Directora del Área, se creó el "Proyecto para la erradicación de la quema de cañaverales junto a los agentes sanitarios del Área Programática Este del SIPROSA". Esto significó ampliar la propuesta a su zona de influencia que incluía, además de las escuelas del departamento Cruz Alta, las de Burruyacú y Leales.

Dentro de las actividades previstas en el proyecto, la Mesa elaboró dos materiales didácticos para acompañar el proceso de aprendizaje de los chicos: el video "Prender fuego no es un juego" y el folleto "Erradiquemos la quema de caña de azúcar" (Anexo 5 y 6), cuyo análisis realizaremos en el próximo apartado.

Entendemos que esta decisión de incluir información en la enseñanza se basa en comprender que "el conocimiento se adquiere mediante un proceso de reflexión individual y colectiva, en el cual la información externa es solamente una parte complementaria a la cultura, el contexto propio, la experiencia vivida, las relaciones sociales y el propio conocimiento local” (Gumucio Dragón, 2009).

También, se realizó un taller participativo con el supervisor del área programática y los 13 supervisores de áreas operativas para discutir y enriquecer la metodología de trabajo construida en la experiencia piloto de Los Ralos.

De este modo, quedó definida una metodología con seis pasos a seguir, donde se aclaraba que era "sólo de carácter orientativo, considerando que cada 
agente sanitario podrá ejecutarla con las variantes que requiera cada situación e incluyendo las técnicas de dinámicas participativas". Así, los agentes trabajarían con los docentes y alumnos del último año de la escuela primaria de la siguiente manera:

Paso 1- Construir los conceptos de la quema junto a los alumnos y docentes, teniendo en cuenta sus conocimientos previos y las experiencias de la vida cotidiana local.

Paso 2- Brindar la charla de un especialista de la salud (médica/os, enfermera/os, agentes sanitarios) sobre las consecuencias de la inhalación de humo.

Paso 3- Reproducir el video y entregar los folletos.

Paso 4- Proponer a los chicos la producción de materiales (maquetas, murales, afiches, volantes, frases radiales, radioteatros, obras de teatro) para informar sobre la problemática a su comunidad. La actividad consistirá en buscar información sobre la quema en sus hogares, junto a los padres, para traer al aula y armar una propuesta entre todos los compañeros del grado. Finalmente, los chicos expondrán los materiales y se reproducirá el video ante todos los alumnos de la escuela.

Paso 5- Organizar un evento local, en cada una de las 13 áreas operativas, para exponer los materiales producidos por las escuelas visitadas.

Paso 6- Organizar una jornada de intercambio de experiencias de toda el Área Programática Este, donde los alumnos expondrán los materiales producidos en un espacio de intercambio y debate junto a los integrantes de la Mesa de Gestión Ambiental de Cruz Alta y representantes del gobierno. Al finalizar el evento, los niños colocarán sus producciones en distintos lugares públicos de la comunidad para informar sobre el tema a sus vecinos.

Otra de las actividades programadas en el proyecto fue la formación de los 13 supervisores de áreas operativas como capacitadores mediante un taller sobre herramientas participativas para el abordaje comunitario a cargo de la Lic. Luisa Vivanco, especialista en la temática. Allí se combinó el aprendizaje de técnicas para lograr un accionar participativo junto a los grupos escolares con la reflexión en 
común sobre la problemática de la quema. Finalmente, los supervisores se encargarían de formar a los agentes a su cargo a partir de lo aprendido.

En la misma reunión los supervisores presentaron el listado de las escuelas que visitarían dentro de su zona de influencia. Esta selección se dejó a criterio de cada agente, de acuerdo a las posibilidades de traslado en función de las distancias y la disponibilidad horaria y de recursos humanos que tenía cada uno.

De este modo, la meta fue trabajar con 160 escuelas en total y realizar 13 eventos locales (uno por área operativa) y la jornada de intercambio del Área Programática Este en el plazo previsto hasta fines del 2011.

En el mes de junio de ese año, después de la entrega de los materiales (video y folleto), se puso en marcha el proyecto con los 290 agentes sanitarios de terreno. El 16 de agosto se realizó un taller de evaluación con los 13 supervisores para analizar los avances y las dificultades que tenían hasta ese momento. Se había cumplido con el $50 \%$ de las escuelas previstas. En cuanto a las dificultades, los agentes plantearon las siguientes:

- Falta de medios de movilidad para trasladarse a las escuelas.

- Problemas para reproducir el video por falta de reproductores de DVD.

- Falta de personal y disponibilidad horaria de los agentes para cumplir con las metas previstas.

- Falta de videos y folletos para entregar.

- Problemas con los directores para realizar los talleres.

Esto permitió introducir algunos mecanismos de ajuste como la entrega del material faltante. Por su parte, el Supervisor de Agentes Sanitarios del Área Programática Este, Sr. Domingo Mirk, se comprometió a resolver los problemas de medios de movilidad y disponibilidad horaria de los agentes, además de hablar con los directores con los que hubo conflictos. Recordemos que este tipo de evaluación es la que se realiza durante la ejecución de los proyectos para determinar si es necesario realizar cambios significativos en el planteo táctico y poder hacerlos ahí.

Sin embargo, esto deja de manifiesto que si bien hubo una programación de las actividades para el diseño de las prácticas pedagógicas a utilizar en el aula y la 
formación de parte de los agentes como capacitadores en la planificación del proyecto, no ocurrió así con la implementación de la metodología para trabajar con las escuelas. En este caso no se definieron las acciones o tareas concretas que generarían los resultados esperados en cada paso de la metodología. Tampoco se evaluaron las condiciones de viabilidad y factibilidad. Con esto nos referimos a considerar "¿Cuáles son los factores que deben garantizarse para favorecer la realización del proyecto? ¿Cuáles son los obstáculos previsibles? ¿Cuáles son las alternativas previstas para su superación?" (Uranga, 2008: 51).

Considerando estas ausencias en la programación tal vez podamos comprender la falta de cumplimiento de las metas al finalizar el plazo estimado para la ejecución del proyecto. A fines de 2011, los agentes sanitarios habían capacitado a 3.995 alumnos en 97 escuelas de Burruyacú, Cruz Alta y Leales. De este modo, se logró cumplir sólo con el 55\% (97 de 160) de las escuelas y el 23\% (3 de 13) de los eventos locales previstos para exponer los materiales producidos por las escuelas visitadas. Mientras que la jornada de intercambio de experiencias de toda el Área Programática Este no se realizó porque el SIPROSA argumentó dificultades para organizarla. Desde la Mesa reconocen que esto se debió a fallas en los agentes sanitarios como responsables de la ejecución de estas actividades.

En este sentido, podríamos considerar entonces que hubo dificultades en el involucramiento y compromiso de los 290 agentes participantes como capacitadores dentro del proyecto, debido a la falta de formación de los mismos como mediadores del intercambio en el acto educativo. Recordemos que sólo participaron de la capacitación los 13 supervisores de áreas operativas. Como sostienen Gumucio Dragón y Tufte (2008: 24), “demasiados proyectos de comunicación en el contexto del desarrollo fracasaron debido a la falta de participación y compromiso de los sujetos/agentes del cambio".

\section{Etapa 2. Productos comunicacionales elaborados}

Para implementar las estrategias destinadas a la concientización y educación de la sociedad, la Mesa de Gestión Ambiental de Cruz Alta diseñó una serie de productos comunicacionales, cuyo proceso de elaboración y ejecución analizaremos a continuación. 
Antes de iniciar este recorrido analítico, es importante considerar que partimos de una concepción que entiende a las tecnologías y su uso no como mera circulación, reproducción, instrumento, sino como prácticas de producción colectiva. Héctor Schmucler (1997: 193) plantea que "lo significativo de una tecnología es el cómo se hace, que normalmente está implícito en el instrumento que se utiliza y que con frecuencia impone su valor cultural sobre el para qué se hace”.

La metodología empleada para la elección de las herramientas a utilizar y la elaboración de los contenidos fue la participativa, a través de reuniones donde cada actor de la Mesa hizo sus aportes. La selección de cada producto respondió a las condiciones de la problemática surgidas en el diagnóstico inicial. Del mismo modo que la construcción de los mensajes se hizo a partir de esta información, sumada a nuevos datos que se fueron generando a lo largo del proceso de desarrollo dinámico de la Mesa.

Para comprender esta vinculación, que detallaremos en el análisis de cada producto, en el siguiente cuadro recuperamos la sistematización de las ideas construidas por los actores en el diagnóstico inicial que elaboramos al comienzo del capítulo. Estas condiciones están vinculadas unas con otras dado que pertenecen al eje común quema de caña y son indisociables tanto en su análisis como en su abordamiento.

\begin{tabular}{|c|c|c|c|c|}
\hline \multicolumn{5}{|c|}{ Demandas } \\
\hline Político & egal & $\begin{array}{c}\text { Social/ } \\
\text { Ambiental }\end{array}$ & $\begin{array}{l}\text { Económico/ } \\
\text { Tecnológico }\end{array}$ & onal \\
\hline $\begin{array}{l}\text { - Falta de } \\
\text { recursos humanos } \\
\text { para aplicar } \\
\text { sanciones ante } \\
\text { incumplimiento de } \\
\text { la legislación. } \\
\text { - Los recursos } \\
\text { provinciales para } \\
\text { actuar en contra } \\
\text { del fuego son } \\
\text { limitados e } \\
\text { inadecuados para } \\
\text { ingresar a los }\end{array}$ & $\begin{array}{l}\text { - Incumplimiento del } \\
\text { Decreto } N^{\circ} 795 / 3 \text {. } \\
\text { - La legislación no } \\
\text { contempla la } \\
\text { situación de los } \\
\text { productores } \\
\text { medianos y grandes } \\
\text { que deben quemar. } \\
\text { - Se debe legislar } \\
\text { de manera } \\
\text { diferenciada los dos } \\
\text { tipos de quema: } \\
\text { caña y maloja }\end{array}$ & $\begin{array}{l}\text { - Costumbre de } \\
\text { quema } \\
\text { generalizada en } \\
\text { la sociedad } \\
\text { tucumana. } \\
\text { - Condena } \\
\text { social hacia los } \\
\text { productores } \\
\text { como únicos } \\
\text { responsables de } \\
\text { las quemas. } \\
\text { - La quema } \\
\text { contamina el }\end{array}$ & $\begin{array}{l}\text { - Los } \\
\text { productores } \\
\text { utilizan la } \\
\text { quema para } \\
\text { abaratar } \\
\text { costos. } \\
\text { - Falta de } \\
\text { alternativas } \\
\text { tecnológicas } \\
\text { para evitar la } \\
\text { quema de } \\
\text { caña y maloja. } \\
\text { - Falta de }\end{array}$ & $\begin{array}{l}\text { - Falta de } \\
\text { campañas de } \\
\text { difusión/comunica } \\
\text { ción para la } \\
\text { prevención de la } \\
\text { quema de } \\
\text { cañaverales. } \\
\text { - Falta de } \\
\text { programas de } \\
\text { educación sobre } \\
\text { la quema de caña. } \\
\text { - Inadecuada } \\
\text { circulación de }\end{array}$ \\
\hline
\end{tabular}




\begin{tabular}{|c|c|c|c|c|}
\hline lotes cañeros. & $\begin{array}{l}\text { - Ambigüedad y } \\
\text { falta de flexibilidad } \\
\text { en la legislación } \\
\text { provincial. } \\
\text { - Los productores } \\
\text { no permanecen en } \\
\text { el lugar del fuego } \\
\text { por miedo a ser } \\
\text { apresados. }\end{array}$ & $\begin{array}{l}\text { medioambiente } \\
\text { y genera } \\
\text { problemas en la } \\
\text { salud de la } \\
\text { población. }\end{array}$ & $\begin{array}{l}\text { acceso a la } \\
\text { tecnología que } \\
\text { permite dejar } \\
\text { de quemar. } \\
\text { - Los } \\
\text { productores } \\
\text { sufren quemas } \\
\text { accidentales o } \\
\text { intencionales } \\
\text { de terceros. } \\
\text { - El productor } \\
\text { es la persona } \\
\text { más } \\
\text { preparada } \\
\text { para apagar } \\
\text { un incendio de } \\
\text { cañaverales. } \\
\text { - Cortes de } \\
\text { servicio de } \\
\text { energía a } \\
\text { causa de la } \\
\text { quema. }\end{array}$ & $\begin{array}{l}\text { información sobre } \\
\text { la problemática en } \\
\text { los medios de } \\
\text { comunicación. }\end{array}$ \\
\hline
\end{tabular}

De acuerdo a estas condiciones, se realizó una estrategia que contempló la integración informativa de lo desarrollado anteriormente en algunos productos comunicacionales. Para el plan de concientización se elaboraron tres afiches, seis comunicados de prensa, un spot televisivo y radial y un folleto. Mientras, para acompañar el proceso de aprendizaje en el aula dentro del plan de mediación pedagógica en las escuelas se elaboró un video y un folleto.

Veamos entonces cómo fue el proceso de creación de los productos, sus formatos y mensajes, cómo se decidió y construyó cada uno, desde qué necesidades surgieron, quiénes participaron en su armado y ejecución.

\section{Afiches y comunicados de prensa}

Para llevar adelante la estrategia de concientización, los actores de la Mesa partieron de la necesidad de enfocar la campaña en la quema generalizada que existe en la sociedad tucumana, donde la responsabilidad del uso del fuego es de 
todos los ciudadanos y no sólo del sector cañero, y en los daños que genera esta práctica para el medioambiente y la salud de la población.

En este sentido, decidieron comenzar en el año 2010 con la realización de dos afiches para ser ubicados estratégicamente en lugares de concurrencia como escuelas, hospitales, comercios, comisarías de las diferentes localidades del departamento Cruz Alta. El objetivo era llamar la atención de los pobladores e introducirlos en la temática de la quema en general, sin relacionarla exclusivamente con el cultivo de la caña de azúcar. Por ello, el aspecto de la problemática que se quiso comunicar fue que "toda la sociedad es responsable de las quemas y las consecuencias afectan a todos".

Para el diseño de los afiches, todos los integrantes de la Mesa se reunieron con el Sr. Mariano Matías, comunicador del INTA EEA Famaillá, para discutir el texto del mensaje y las imágenes que lo acompañarían. De este modo, se eligieron dos frases, una para cada afiche. La primera, "Quemar nos hace mal a todos", se acompañó con la imagen de un fósforo encendido con llama y humo. La segunda, "Prender fuego no es un juego", fue aportada por los agentes sanitarios del Hospital Los Ralos y se convirtió en el slogan de la campaña de concientización y educación. En este caso, la frase estuvo acompañada por la imagen de varios fósforos sin encender.

Los mensajes de los afiches manifiestan la intención de la Mesa de involucrar a los ciudadanos en la responsabilidad del uso del fuego, tanto en las causas como en las consecuencias del mismo.

Ambos productos llevaron el logo de los actores que participaban en la Mesa en ese momento: Dirección de Flora y Fauna, Dirección de Defensa Civil, INTA, Empresa Agrícola Juan José Budeguer y Productores Cañeros ${ }^{43}$, bajo el título "Campaña de Prevención de Incendios".

Dentro de la misma estrategia y con igual metodología se realizó un afiche destinado a los productores para ser colocado en la puerta de los ingenios del Este de la Provincia. En este caso, los productores sugirieron que el mensaje fuera positivo para evitar el rechazo del sector que se siente condenado socialmente como único culpable de las quemas. Por ello, el aspecto que se decidió comunicar fue "la sugerencia de mejora de las prácticas de manejo del cultivo a fin de evitar el

\footnotetext{
${ }^{43}$ Este logo fue creado en ese momento para representar al resto de los productores integrantes de la Mesa.
} 
uso del fuego como herramienta de producción y las quemas accidentales o intencionadas de terceros en sus campos".

La frase elegida fue "Quemar caña nos afecta a todos. Trabajemos día a día para controlarlo mejorando las prácticas culturales". Y se pusieron cuatro recuadros con recomendaciones expresadas mediante una frase acompañada por una imagen: "Callejones limpios", "Cosecha integral en verde", "Limpieza bajo tendido eléctrico", "Incorporación del rastrojo".

El financiamiento de los afiches se realizó con fondos aportados por el INTA y los productores. Para la colocación de los materiales no hubo una planificación donde se pautaran tiempos, lugares y responsables de la distribución, sino que cada integrante de la Mesa se encargó de ubicarlos en las escuelas, hospitales, comercios, comisarías e ingenios dentro de su zona de trabajo.

De este modo, si bien se logró difundir los afiches para introducir a los pobladores en la temática, la estrategia se vio discontinuada hasta el año 2012 cuando se elaboró un spot televisivo y radial y un folleto para profundizar sobre las causas y consecuencias de la quema como se había propuesto al principio.

Esto puede deberse a la inexistencia de una programación, que mencionábamos en la descripción de la estrategia de concientización, donde se definieran las metas y resultados esperados con las tareas y recursos necesarios para alcanzarlos. Recordemos que una planificación que sirva como marco y referencia permite brindar coherencia y continuidad a la selección, producción, contenidos y ejecución de los productos comunicacionales elaborados.

Por otra parte, ante la demanda surgida en el diagnóstico inicial sobre la "falta de información sobre la problemática en los medios de comunicación", la Mesa decidió utilizar los comunicados de prensa para dar a conocer su propuesta de programa de erradicación progresiva de la quema y su visión sobre la complejidad de la problemática. Entendemos a los mismos como la información escrita o grabada que proporciona una institución u organización, sea pública o privada, a los medios de comunicación con el objetivo de anunciar algo que podría revestir interés periodístico.

Durante los tres años de ejecución del programa de erradicación se difundieron seis comunicados escritos. El proceso de elaboración de cada uno comenzaba con la definición del contenido donde participaban todos los integrantes de la Mesa. Luego, por pedido de los actores, la tarea de redacción del texto estaba 
a mi cargo por ser comunicadora. Esto da cuenta de una mirada sobre el rol del comunicador como el encargado de traducir los mensajes para poder transmitir lo que se desea. Una vez redactado el texto, era enviado vía mail a todos para que realizaran modificaciones y/o agregados.

La difusión de los comunicados se realizaba entre la agenda de medios del INTA Famaillá, que incluye diarios, revistas y programas de radio y TV de San Miguel de Tucumán y el país. Además, se los publicaba en formato de notas en el Boletín Noticias de la Institución. Se trata de un boletín electrónico quincenal, que es distribuido de manera interna al personal y externa a las agendas de productores de las diferentes cadenas (caña de azúcar, apicultura, frutihorticultura, granos, frutas finas, forestales y citrus), la prensa y estudiantes e instituciones del medio.

Así, se logró una baja aparición y sólo en algunos medios de la capital tucumana, sin llegar específicamente a los pobladores de Cruz Alta. Aquí queda expuesta la falta de un diagnóstico que permitiera identificar los espacios mediáticos potenciales para la difusión de la información dentro del contexto de influencia de la organización y los medios más significativos para los interlocutores, a fin de poder planificar una estrategia con productos acordes a esos resultados. En este sentido, por ejemplo, no hubo una estrategia específica para distribuir los comunicados en los medios radiales y televisivos que son los de mayor alcance en las zonas rurales del interior de la provincia.

Es importante reconocer la importancia que reviste el relacionamiento con los medios de comunicación para organizaciones como la Mesa de Gestión Ambiental de Cruz Alta que buscan instalar el tema de su interés en el ámbito público, entendido como "lo que conviene a todos, de igual manera, para su dignidad" (Toro y Rodríguez, 2001: 5).

En este sentido, Claudia Villamayor (2002: 34) afirma que "la centralidad de la massmediación y la importancia que esto tiene para todo tipo de organizaciones sean estatales, privadas o privadas con fines públicos es un dato con el que convivimos en nuestra vida cotidiana. Sin embargo, son pocos los casos en los que la organización ha diseñado una estrategia para lograr una permanencia en los medios de comunicación o para colocar en la agenda pública sus problemáticas de interés, aunque todas reconocen la necesidad de tal estrategia".

Por lo tanto, hablamos de que la relación con los medios requiere de la planificación y gestión de una estrategia que permita conducir a los objetivos 
deseados y evitar la improvisación. "No se diagnostica sino para poder planificar mejor. No se planifica sino en función de diseñar de la manera más adecuada una gestión de estrategias comunicacionales orientadas a mejorar la manera de llevar adelante la tarea de una organización, de una institución, de una empresa o de un grupo social" (Uranga, 2001: 37).

De esta manera, durante el año 2010 se realizaron tres comunicados. El primero, titulado "Todos por la erradicación progresiva de las quemas en Tucumán", describía el proceso de creación de la Mesa, los integrantes y su propuesta para trabajar con los productores y la sociedad. La que hablaba en este caso era la organización, pero en tercera persona.

El relato se iniciaba explicando las consecuencias del uso del fuego y los múltiples orígenes de esta práctica en los campos, lo cual deja manifiesta la intención de la organización de reconocer a todos los ciudadanos como responsables de las quemas en los cañaverales y no sólo a los productores.

En este sentido, explicaba que "la quema de residuos está generalizada en la sociedad tucumana (quema de "limpieza" de banquinas, residuos domiciliarios, para apertura de montes, etc.); otras veces constituye un descuido (quemas iniciadas por colillas de cigarrillos, fuegos mal apagados, etc.); o es un método de daño intencional a las propiedades (personas ajenas a las explotaciones cañeras). $A$ ello se suman las quemas de caña en pie o residuos de cosecha como práctica de producción por parte de algunos productores".

Se utilizó esta fundamentación como introducción para explicar la decisión de la Mesa de trabajar tanto con los cañeros como con la sociedad en general dentro de su programa de erradicación progresiva de la quema.

El comunicado contaba con dos subtítulos: "Los focos de fuego detectados por el INTA" para explicar por qué la Mesa trabaja sólo en el departamento Cruz Alta, aclarando que "si bien la quema de residuos vegetales es un problema de toda la provincia de Tucumán y de diversas producciones, Cruz Alta es uno de los Departamentos donde se registró la mayor cantidad de focos de fuego sobre superficie de caña de azúcar en los últimos años”. El otro subtítulo, “¿Qué es un incendio y una quema controlada?", señalaba esta distinción realizada por la Mesa dentro de las directrices del plan destinado a los productores.

En el mes de septiembre, con la realización del "Encuentro prender fuego no es un juego" como cierre de las experiencias piloto de mediación pedagógica en las 
escuelas de Los Ralos, se difundieron dos comunicados de prensa. Uno para invitar al evento y el otro, una vez finalizado el mismo, para describir lo vivenciado durante la jornada y rescatar los materiales producidos por los chicos. Si bien en ambos casos la que relataba el proceso era la Mesa, en el último parte se buscó visibilizar la voz de los chicos para mostrar el producto de la construcción en común sobre la realidad de la quema.

De esta manera, se expusieron textualmente algunas de las frases creadas por los niños en las maquetas, murales, afiches, volantes y frases radiales para informar a sus vecinos:

- No a la quema de caña. Por favor no quemen ustedes gente de Ralos, se van a dar cuenta que el humo que se produce nos perjudica. iSean conscientes con lo que hacen!

- Compañeros no debemos quemar las cañas, eso podría causar mucho daño, si las cañas están cerca de una autopista podría causar un choque o también si está cerca de una casa podría quemarla. Compañeros pensemos las cosas antes de hacerlas. Pensemos en lo que puede pasar.

- Debemos prevenir la quema de caña. Esto perjudica la salud de todos. Nosotros debemos cuidar el medioambiente. Por eso cuidemos nuestro planeta. No se puede quemar la caña en pie. Por favor, si ves que va a empezar un incendio llama al 103 a Defensa Civil.

- No a la quema de cañaverales porque es perjudicial para la salud. Pongamos todos un granito de arena y evitemos contaminar.

- ¿QQuerés que los chicos tengan un futuro mejor? Dale, no quemes.

- Juntos podemos cuidar nuestro ambiente.

- Basta de cubrirme el aire y matarme los sueños.

- Una sola chispa de fuego puede desencadenar un incendio furioso convirtiendo en cenizas todo nuestro sueño o esperanza.

En estos relatos se manifiesta la reflexión de los niños sobre los daños que genera la quema de cañaverales en la población y la responsabilidad de los ciudadanos de trabajar en la prevención. 
Por último, el comunicado mencionaba que "se generó un espacio de intercambio y debate entre los alumnos y docentes de las escuelas y los integrantes de la Mesa de Gestión Ambiental', cuando en realidad sólo se hizo una exposición y recorrido por los materiales producidos y se escuchó un programa de radio elaborado por la Escuela Eudoro Avellaneda.

En el 2011, la Mesa elaboró dos comunicados de prensa más. El primero se utilizó para la difusión del "Compromiso de adhesión voluntaria al programa piloto de erradicación de la quema de caña de azúcar en el departamento Cruz Alta, Tucumán". En este caso, la Mesa hablaba en primera persona, invitando a los productores a adherirse al programa.

Para ello, se decidió realizar un comunicado corto de tres párrafos con información concreta sobre la propuesta y los datos de contacto. Así, en el texto se relataba el objetivo del programa y las características de los interlocutores a los que estaba destinada la propuesta: "ordenar la quema controlada de caña de azúcar a cosechar en forma manual y/o semi-mecanizada, con un régimen para los productores minifundistas menores de 50 hectáreas. El objetivo es eliminar el 100\% de esta práctica antes de 2024 en el territorio departamental". Finalmente, se informaba sobre los datos de contacto para realizar el trámite en la sede de la Agencia de Extensión Rural Banda del Río Salí del INTA.

El segundo comunicado, titulado "Los niños tucumanos nos enseñarán a cuidar el medioambiente", se difundió en el mes de junio para dar a conocer el proyecto que se implementaría con los agentes sanitarios del SIPROSA. En el mensaje se destacaba como finalidad de la propuesta "trabajar con los niños como educadores de su comunidad", describiendo la metodología que se utilizaría para ese fin.

Además, se rescataba la vinculación de la Mesa con el SIPROSA para diseñar y ejecutar esta propuesta. En este sentido, planteaba que "a partir de la exitosa experiencia piloto realizada en 4 escuelas de Los Ralos en el 2010, el Sr. Ariel Leiva -Supervisor de Agentes Sanitarios del Área Operativa Los Ralospropuso ampliar esta propuesta a toda el Área Este de Tucumán. Así nació este proyecto, que fue presentado ante la Directora del Área Programática Este del SIPROSA, Dra. Irma Díaz". Este relato deja entrever la clara intención de la organización de mostrar la vinculación con otros actores del territorio y reconocer el 
apoyo y aporte de un organismo gubernamental como el Sistema Provincial de Salud para su trabajo en terreno.

Como propone Claudia Villamayor (2006: 5), "la multiplicidad construye otra forma de liderazgo que ya no se asienta en una o dos personas sino en la gestación de colectivos humanos capaces de generar procesos creativos de construcción en red".

Por último, en el 2012, la Mesa realizó un solo comunicado en el mes de junio con el objetivo de mostrar los logros alcanzados durante los dos primeros años de trabajo en el territorio. Bajo el título "Avances en la erradicación de la quema de caña de azúcar" se expusieron algunos resultados en el trabajo con los productores y la sociedad logrados hasta ese momento.

En el primer caso se destacaba que "un importante número de productores de Cruz Alta ya firmó el compromiso". Además, que "se observa una reducción de la quema de caña en pie y una importante mejora de las prácticas culturales por parte de los productores del Este de la Provincia como es la limpieza de callejones que funciona como cortafuegos. Por otra parte, se detecta una mayor inversión de los establecimientos más grandes para la puesta en funcionamiento de mecanismos para evitar incendios". Sin embargo, estas afirmaciones no estuvieron fundamentadas en datos que den cuenta de esas transformaciones.

En cuanto a la educación de la sociedad civil, en el texto se reconocía que la puesta en marcha del proyecto con los agentes sanitarios en el 2011 había "permitido que 3.995 alumnos de 97 escuelas de Burruyacú, Cruz Alta y Leales reflexionaran sobre la problemática de la quema y concientizaran a sus vecinos sobre la importancia de evitar las quemas accidentales o intencionadas".

Con respecto al plan de concientización, se destacaba como logro la realización de nuevos productos comunicacionales como el folleto y el spot televisivo y radial que sería difundido en los medios de comunicación de la Provincia.

Como mencionábamos al comienzo, con la difusión de estos comunicados a través de la agenda de medios del INTA la Mesa no logró una permanencia en los medios de comunicación para colocar su propuesta sobre la problemática de la quema en la agenda pública. 
En cambio, la mayor exposición la logró en el año 2012 cuando fue invitada por la Defensoría del Pueblo y la Comisión de Medio Ambiente de la Legislatura de Tucumán para exponer su programa de erradicación progresiva de la quema. Este hecho atrajo la atención de la prensa. Así, en ambas reuniones, los integrantes de la organización fueron entrevistados por los diarios, radios y canales de televisión locales, logrando visibilizar sus voces con un mayor alcance. La Gaceta, principal medio gráfico de la Provincia, publicó durante una semana noticias sobre la propuesta de la Mesa para erradicar la quema, lo que fue replicado por otros medios de la Provincia y el país. (Anexo 7)

\section{Video y folleto "Prender fuego no es un juego"}

Dentro del Proyecto para la erradicación de la quema de cañaverales junto a los agentes sanitarios del Área Programática Este del SIPROSA, en el año 2011 la Mesa elaboró un video y un folleto para acompañar el aprendizaje de los chicos en las escuelas.

El proceso de producción del video fue el que más tiempo y discusiones demandó en relación al resto de los productos comunicacionales. Durante dos reuniones, la discusión se centró sobre los aspectos de la problemática que debían estar presentes en el mensaje.

En este sentido, cada integrante de la Mesa hizo sus aportes en función de su rol e intereses sobre la problemática de la quema, lo cual, de alguna manera, se relacionaba con los datos surgidos en el diagnóstico inicial realizado. Así, mientras los productores propusieron exponer los múltiples orígenes y responsables de las quemas; Defensa Civil pidió que se explique qué hacer ante un incendio de cañaverales; EI SIPROSA planteó describir las consecuencias de la quema, especialmente en la salud de la población; desde INTA se propuso sugerir las acciones ciudadanas que permiten evitar las quemas e incluir la participación de los alumnos de la Escuela La Lolita de Los Ralos ${ }^{44}$ y de un médico en la realización del video.

Una vez apuntadas las sugerencias, la tarea de condensarlas en la redacción de un guion estuvo a mi cargo junto a la Ingeniera Cristina Biaggi del INTA. Y con esa primera versión nos reunimos con la Empresa Área Audiovisual

\footnotetext{
${ }^{44}$ La elección de la Escuela La Lolita respondió a que se encuentra ubicada en una zona rural de Los Ralos rodeada de cañaverales.
} 
para plantearle la propuesta. En cuanto a la estética del video, considerando que estaría destinado a alumnos del nivel primario de acuerdo a lo planificado en el proyecto, se decidió combinar dibujos con imágenes reales.

Para la grabación de las imágenes se utilizó como locación el predio donde funciona la Escuela La Lolita, rodeada de cañaverales. Se realizó la puesta en escena con los alumnos, docentes, un médico comunitario y los agentes sanitarios de Los Ralos. Los chicos prepararon afiches y unas frases relacionadas con la erradicación de la quema para la filmación.

De allí surgió la primera versión del video, que fue expuesta ante los actores de la Mesa para que realizaran críticas y sugerencias. Los cambios propuestos fueron los siguientes:

- Incluir frases positivas que motiven una actitud proactiva de la población en relación a la quema de caña.

- Eliminar algunas imágenes de cañaverales quemándose porque son demasiado fuertes.

- Explicar la importancia del cultivo de caña para la Provincia.

- Explicar por qué los productores aún deben utilizar la quema.

- Mencionar que la quema como herramienta de producción se está erradicando.

- Explicar el esfuerzo que están realizando los productores para eliminar esta práctica.

Con estas modificaciones quedó la versión definitiva del video, titulado "Prender fuego no es un juego. Material pedagógico para debatir en las escuelas", firmado por el INTA -que financió su realización- y la Mesa de Gestión Ambiental de Cruz Alta.

Finalmente, mostrando los diversos aspectos de la problemática sugeridos por los actores, el contenido del video focalizó sobre la importancia económica de la producción cañera para Tucumán; los motivos por los cuales los productores más pequeños y medianos utilizan la quema y el esfuerzo que realizan para evitar los incendios; las diversas causas y responsables de las quemas de cañaverales; las 
consecuencias de todo tipo que genera el uso del fuego; las acciones ciudadanas que pueden evitar una quema y las prohibiciones absolutas para quemar cualquier tipo de vegetación contempladas en el Decreto № 795/03.

Esta descripción realizada por la Mesa da cuenta de su objetivo de abordar la condena social que existe sobre el sector cañero, mostrando la responsabilidad de todos los ciudadanos en el inicio y prevención de las quemas y el esfuerzo que están realizando los productores para evitar los incendios. En este sentido, expresaba que "los productores están trabajando para evitar los incendios de cañaverales con la mejora de las prácticas en sus lotes: callejones limpios, cosecha integral en verde, limpieza bajo tendidos eléctricos e incorporación del rastrojo".

Considerando que el material estaba destinado a acompañar el proceso de aprendizaje de los chicos en las escuelas, en el relato la Mesa hablaba en primera persona utilizando frases que motiven una actitud proactiva a lo largo de todo el guion: "Todos podemos cuidar a la principal producción agrícola de nuestra provincia", "Entre todos podemos evitar los incendios de cañaverales y cuidar al ambiente y a nuestros vecinos. Sumáte vos también", "Vos también podés ayudarnos a erradicar la quema", "Te invitamos a sumarte a la Brigada Ecológica de tu ciudad para evitar incendios de cañaverales y concientizar a tus vecinos sobre la importancia de cuidar el medioambiente y la salud de todos nosotros", "Trabajemos juntos para la erradicación de la quema de cañaverales”. Esto se acompañó con imágenes de los alumnos de la Escuela La Lolita sosteniendo sus afiches con frases relacionadas con la erradicación de la quema.

El video fue utilizado por los agentes sanitarios en las 97 escuelas de Burruyacú, Cruz Alta y Leales que visitaron en el 2011. Siguiendo la metodología de trabajo prevista, el material fue reproducido por los capacitadores después de construir los conceptos de la quema junto a los alumnos y docentes y brindar la charla de un especialista de la salud.

Dentro de la misma propuesta, pensando en los alumnos como educadores de su comunidad, la Mesa elaboró un folleto con el mismo contenido y algunas imágenes del video. El formato fue un tríptico, de acuerdo a la cantidad de cuerpos del material. El objetivo era que los chicos pudieran llevar un material impreso que contenga información sobre la quema a sus hogares a fin de informar a sus familias. De este modo, los 3.995 alumnos y docentes que participaron del proceso de aprendizaje junto a los agentes sanitarios recibieron el folleto. 


\section{Spots y volante "Entre todos podemos cuidar nuestra provincia"}

En el año 2012, con una práctica de dos años de la Mesa en el territorio y una construcción de la realidad de la quema más consolidada, continuó la campaña de concientización con la producción de un spot televisivo y radial y un volante. El objetivo era profundizar el aspecto de la problemática que se abordó en los afiches: la quema es responsabilidad de todos y afecta a toda la sociedad.

Para lograrlo, en el momento de diseñar el mensaje, los actores de la Mesa coincidieron en que debía centrarse en las acciones que pueden llevar adelante los ciudadanos para evitar las quemas por las consecuencias que genera para el ambiente y la población. Por su parte, los productores insistieron en utilizar frases positivas que propicien una actitud proactiva en la gente. Mientras, desde el INTA propusimos utilizar una estética basada en dibujos para que los materiales resultaran más amigables y pudieran ser entendidos por adultos y niños.

Considerando todos los aportes, quedó definido el siguiente texto para el guion: "La caña de azúcar es el principal cultivo de Tucumán y debemos cuidarlo. Cualquier fuego puede pasar a los cañaverales y provocar un incendio. Por eso: no quemes la basura de tu casa, es mejor enterrarla; no arrojes fósforos o colillas de cigarrillo en lugares que puedan incendiarse; no prendas fuego los cañaverales y pastizales. Si se quema la caña perdemos todos: intoxicación con humo, accidentes en rutas, apagones en la ciudad. Entre todos podemos cuidar a nuestra Provincia". En este relato se visibiliza la intención de la Mesa de considerar a los ciudadanos como responsables de la prevención de los incendios y como los principales perjudicados con las consecuencias de esta práctica.

Para la realización de los materiales, la Mesa contrató a la Empresa Área Audiovisual, con la que había diseñado el video para trabajar con las escuelas el año anterior. A partir del guion entregado por la organización, la empresa se encargó de diseñar la gráfica del spot televiso y el volante y la grabación del spot radial.

En el caso del micro para televisión, se reemplazó parte del texto con imágenes para describir las acciones que pueden realizar los ciudadanos para evitar las quemas y las consecuencias de esta problemática. Mientras, en el micro radial se utilizó el texto completo relatado por un locutor. En cuanto al volante, también se usó todo el texto acompañado por imágenes. 
Tanto el producto gráfico como el audiovisual terminan con la firma de la Mesa de Gestión Ambiental de Cruz Alta y los logos de los actores que participaban en ese momento: Dirección de Defensa Civil, SIPROSA, INTA, Dirección de Fiscalización Ambiental, Empresa Agrícola Juan José Budeguer, Productores Cañeros, Cañeros Unidos del Este y Asociación de Bomberos Voluntarios de Las Talitas.

Una vez entregada la primera versión de los materiales, los integrantes de la Mesa propusieron realizar algunos cambios. Con la modificación de la música, por ser considerada muy lenta, y el agregado de más imágenes que representen las consecuencias de la quema quedó la versión definitiva de los productos.

La producción de los micros y el diseño del folleto se realizaron con fondos aportados por la Empresa Agrícola Juan José Budeguer. Mientras, las Direcciones de Defensa Civil y Fiscalización Ambiental fueron las encargadas de gestionar la publicación de los spots en los principales medios de comunicación (Canal 8, Canal 10, Canal 5, CCC, Radio LV12, Radio LV7, Radio Antena 8, Radio Universidad, entre otros) a través del Gobierno de la Provincia.

Desde el Área de Prensa y Difusión del gobierno rechazaron la difusión de los micros, argumentando que el mensaje debía estar dirigido a los productores y no a la sociedad como responsable de las quemas. $Y$ explicaron que ellos ya venían utilizando una propaganda sobre el tema. La respuesta de la Mesa fue que el contenido de su propuesta se basaba en un diagnóstico sobre la problemática, donde surgió que el spot que ellos utilizaban causaba el rechazo de los productores. Además, considerando que la erradicación de la quema implica un cambio tecnológico profundo que ofrece resistencias de los mismos, explicaron que la publicidad como herramienta no era efectiva en ese caso, por lo que se debía buscar otra estrategia comunicacional para trabajar con el sector.

El argumento del gobierno da cuenta de la mirada instrumental con que se maneja la comunicación en algunos estratos políticos, donde se privilegia la difusión de mensajes publicitarios para demostrar que se está trabajando en problemáticas que afectan a la ciudadanía. Pero, la existencia de un diagnóstico, la planificación y gestión de una estrategia y un sistema de evaluación que sirvan como base para la elaboración y publicación de este tipo de productos está ausentada por completo.

Finalmente, ante la negativa del Área de Prensa y Difusión, los micros no se publicaron en los principales medios de Tucumán porque la Mesa no contaba con 
fondos para financiar su difusión. Tampoco realizó gestiones, por su cuenta, con cada medio radial o televisivo para ver las posibilidades de publicación. Así, los spots sólo fueron distribuidos entre la agenda de medios del INTA Famaillá, logrando aparecer en las páginas web de algunos de ellos y en las del Ministerio de Producción de la Provincia y el INTA. En cambio, los volantes sí fueron distribuidos por los agentes sanitarios en las visitas domiciliarias que realizan habitualmente en su zona de influencia.

Otra vez queda de manifiesto las dificultades que generó la falta de programación en el plan de concientización, especialmente con la definición previa de los recursos necesarios y las condiciones de viabilidad y factibilidad para difundir los spots en este caso. Del mismo modo que no se identificó y caracterizó a los interlocutores (los pobladores de Cruz Alta) ni a los medios más significativos para ellos a fin de definir los espacios mediáticos más adecuados para su difusión.

La principal sensación que surge después de realizar este recorrido analítico sobre el proceso de construcción y ejecución del programa de erradicación de la quema de la Mesa es la dificultad de lograr las transformaciones deseadas cuando no se trabaja desde la planificación y gestión de las estrategias dentro de un proyecto. Del mismo modo, el hecho de no lograr comprometer e involucrar a todos los participantes de las estrategias dificulta el desarrollo del proyecto.

Bernardo Toro y Martha Rodríguez (2001: 4) sostienen que "todo proyecto, programa o reforma que involucre la acepción o el compromiso de la voluntad de los afectos (positiva o negativamente) debe poner especial atención a las estrategias comunicativas. Si la propuesta de reforma o el proyecto no tienen sentido para los implicados, la implementación tiene muchas dificultades y la sostenibilidad es dudosa".

Sin embargo, consideramos importante reconocer que la Mesa logró reunir y poner a dialogar a los diferentes actores vinculados a la quema de caña de azúcar en el territorio para pensar la transformación. También pudo diseñar una metodología para involucrar a los niños en la construcción de los conocimientos sobre la problemática, proponiéndolos además como educadores de su comunidad.

Esto nos demuestra que existen posibilidades dentro de la organización de rediseñar sus estrategias, trabajando desde una mirada de la comunicación concebida como instancia de puesta en común, donde la participación y la construcción conjunta son elementos indispensables. 
Es justamente esta instancia de puesta en común entre los actores lo que valoran los integrantes de la Mesa como la mayor fortaleza de la organización. Por esto, a continuación, rescatamos las opiniones de los actores surgidas en las entrevistas que realizamos, exponiéndolas como fundamento de esta afirmación:

En este sentido, el productor cañero Manuel Ponce ${ }^{45}$ explica que el valor de la Mesa radica en "haber logrado que sea un espacio de debate entre instituciones, autoridades y productores, exponiendo distintas visiones para lograr converger en un mismo objetivo".

Por su parte, Juan Ullivarri de la Estación Experimental Agroindustrial Obispo Colombres $^{46}$ plantea que "creemos que la MGA es la iniciativa más importante que se realizó en los últimos años para abordar el problema de la quema. Por lo tanto, es importante que la EEAOC tenga participación en esta iniciativa, ya que incorpora a la mayoría de los actores implicados en resolver este problema".

Lourdes Fernández Poblete, Presidente de la Asociación Bomberos Voluntarios Las Talitas ${ }^{47}$, sostiene que "la Mesa de Gestión Ambiental es un espacio donde todos los que integramos estamos dispuestos a cambiar y modificar costumbres. Es un poco difícil, pero con la constancia y la prevención se irá logrando proteger el medioambiente. Se ha logrado mucho con la participación de diferentes entes y organizaciones como particulares, lo que es muy difícil lograr. Me siento muy halagada, como muy comprometida en ser parte de la Mesa. Le doy un $80 \%$ de positivo al año 2012".

La opinión de Juan Izquierdo de la Empresa TRANSENER ${ }^{48}$ es que la Mesa "nos permitió conocer distintas opciones contadas por las personas involucradas que nosotros no teníamos sobre esta problemática, algo que nadie había podido lograr. Para nosotros también fue muy importante la Mesa, ya que a través de ella nos contactamos con gente de Fiscalización Ambiental y pudimos llegar a las autoridades provinciales con rapidez".

Emiliano Hernández, representante de la Empresa Los Cevilares ${ }^{49}$, en el balance del proceso transcurrido sostiene que "sin atacar ni defender quién quema y quién no, creo que hemos ido a la solución del problema. Nosotros como Mesa,

\footnotetext{
${ }^{45}$ Entrevista personal, 12 de diciembre de 2012.

${ }^{46}$ Entrevista personal, 12 de diciembre de 2012.

${ }^{47}$ Entrevista personal, 13 de diciembre de 2012.

${ }^{48}$ Entrevista personal, 14 de diciembre de 2012.

${ }^{49}$ Entrevista personal, 13 de diciembre de 2012.
} 
desde el lado técnico nos planteamos como un cuerpo de consulta, de desarrollo de nuevas cosas, que es lo que más sabemos hacer".

El representante de la Fundación ProYungas y la Defensoría del Pueblo, Sebastián Malizia ${ }^{50}$, explica que "la Mesa de Gestión Ambiental de Cruz Alta es muy útil ya que en el tema quema de caña es el único ámbito que conozco que ha logrado reunir en una misma mesa a productores grandes y chicos, organismos del estado, instituciones técnicas, organizaciones de la sociedad para, entre todos, abordar una situación que se percibe como un problema. Ya eso, convocar a todos estos sectores, es una ganancia".

Cristina Biaggi del INTA ${ }^{51}$ sostiene que "la Mesa de Gestión Ambiental de Cruz Alta se convirtió en un agente de extensión y capacitación en el territorio, además de ser un espacio de encuentro y búsqueda de alternativas para la erradicación de la quema, tanto para los que la componen como para los productores preocupados por la problemática".

Con estas palabras queda en evidencia que La Mesa se consolidó como un espacio de intercambio de saberes y opiniones, de construcción de una nueva forma de pensar la problemática de la quema de caña de azúcar. Los actores involucrados lograron sentirse cómodos, en confianza y en un ambiente de respeto para trabajar en común. De esta manera, queda abierta la posibilidad de continuar con el diagnóstico de los procesos comunicacionales desarrollados en la Mesa de Gestión Ambiental de Cruz Alta en el próximo capítulo para construir junto a los actores las líneas de acción comunicacionales que permitan rediseñar las estrategias de la organización.

${ }^{50}$ Entrevista personal, 14 de diciembre de 2012.

${ }^{51}$ Entrevista personal, 22 de diciembre de 2012. 
Para concluir con el diagnóstico de los procesos comunicacionales desarrollados en la Mesa de Gestión Ambiental de Cruz Alta, en el capítulo final nos centraremos en la construcción de las líneas de acción comunicacionales para rediseñar las estrategias de la organización en pos de aportar a lograr nuevas transformaciones respecto de la práctica de la quema en el cultivo de caña de azúcar en un departamento de la provincia de Tucumán.

Entendemos líneas de acción como puntos de partida para la planificación de estrategias comunicacionales, generando las condiciones para crear procesos de cambio. Se trata de "orientaciones de carácter general que expresan la importancia y necesidad de operar sobre determinados niveles o aspectos de la comunicación, sin precisar las cuestiones relativas a la organización, coordinación y ejecución de las acciones. Son un insumo para la discusión y formulación de los objetivos general y específicos de la planificación" (Villamayor, 2002: 51).

La construcción de las propuestas de cambio en este apartado se llevará adelante de manera participativa junto a los actores de la Mesa, en una interlocución permanente, que reconoce el conflicto como dinamizador del debate colectivo. Como afirma Dora Schnitman (1998: 27), "devenir un ser humano consiste en participar en procesos sociales compartidos en los cuales emergen significados, sentidos, coordinaciones y conflictos [...] El surgimiento de una conciencia creciente de la discontinuidad, de la no linealidad, de la diferencia y la necesidad de diálogo como dimensiones operativas de la construcción de las realidades en que vivimos".

Nos referimos a impulsar el mayor grado de participación posible de los actores en el diagnóstico, transformando a los miembros de la organización en corresponsables del mismo. Claudia Villamayor (2002: 33) plantea que "este diagnóstico se denomina participativo y su puesta en práctica no sólo mejora los niveles de eficacia, propicia la construcción de un lenguaje común a partir de la diversidad, compromete a los actores con el proceso de cambio, sino que se constituye en una instancia de aprendizaje acerca de un modo de 'pensarse' como organización y proyectarse hacia el futuro".

En este sentido, entendemos que el único cambio posible es el que surge desde adentro de la organización, ya que la participación y el aporte de los sujetos se da sólo en torno a cuestiones reconocidas por ellos como problemáticas, en el 
sentido de que responden a sus necesidades e intereses actuales. Considerando que los integrantes de la Mesa son los protagonistas del cambio, será más adecuado que se proyecten en común los caminos a desarrollar para la planificación de esa transformación. Esto permite sumar saberes, miradas, experiencias y buscar, de manera colectiva, las mejores estrategias para llevar a cabo la misión.

Entonces, para trabajar sobre la propuesta de las acciones orientadas al cambio nos basaremos en una práctica comunicacional de la Mesa de Gestión, cuya realización se articuló con la necesidad de concluir la etapa final del diagnóstico comunicacional considerado en esta tesis posgradual.

Nos referimos al "Taller de evaluación y construcción de las propuestas de cambio", realizado en dos jornadas el 18 de octubre y el 20 de diciembre del 2012. En estas reuniones, los actores de la Mesa junto al equipo investigador evaluamos las dificultades y los logros alcanzados con el programa de erradicación progresiva de la quema en los tres años de ejecución en el territorio. A partir de allí, hicimos un análisis y valoración de las debilidades y fortalezas en relación a la gestión de la organización dentro de su contexto social histórico determinado, a fin de identificar los nudos críticos que pudieran convertirse en futuras líneas de acción para la transformación.

De este modo, después de transitar el largo proceso de investigación para la acción desde la perspectiva PLANGESCO que iniciamos al comienzo de esta tesis, llegaremos al final del recorrido logrando cumplir con los dos objetivos específicos que nos propusimos para diagnosticar los procesos comunicacionales desarrollados en la Mesa de Gestión Ambiental de Cruz Alta:

- Describir, analizar y evaluar los procesos comunicacionales -procesos de diálogo y productos- desarrollados en y por la organización, a través de las etapas de diagnóstico, planificación y gestión.

- Proponer líneas de acción comunicacionales a partir de los problemas construidos a lo largo de la investigación.

Recordemos que la construcción diagnóstica dinámica y participativa de la Mesa en esta tesis se realiza desde una mirada comunicacional, que entiende a la comunicación como relación social y cultural con sujetos que interactúan en 
prácticas socio-culturales donde intervenimos para diseñar procesos de cambio planificado.

Llevamos adelante una propuesta epistemológica de intervención social y política, que implica una mirada propia desde el campo de la comunicación para planificar y gestionar un proceso de transformación. Porque uno de los principales desafíos para nosotros como investigadores en la actualidad es reconocer que "trabajamos con objetos que en realidad son procesos" (Foerster, 1984, citado por Massoni, 2007: 21).

En este sentido también reflexiona José Piñuel Raigada (1997: 14) cuando propone que:

El objeto de las ciencias sociales es siempre un objeto histórico, es decir, que el propio conocimiento a que aspiramos, el conocimiento científico, es una realidad material (una práctica humana) que se modifica y cambia por la propia actividad de los que, produciéndola, hacen ciencia. De esta manera el conocimiento [...] es una realidad efectiva por la que los sujetos que lo aplican renuevan sus prácticas, repitiéndolas y, a la vez, innovándolas (reproducción), y el conocimiento se hace colectivo por el intercambio comunicativo (dialéctica) y por la experiencia de transformación del entorno, etcétera.

Con esta propuesta como punto de partida, comenzamos el recorrido analítico-reflexivo de esta investigación con un registro de las condiciones políticas, productivas-económicas y sociales existentes en Tucumán y en el departamento Cruz Alta, permitiéndonos situar contextualmente la práctica para construir el diagnostico en la tesis.

De esta manera, pudimos reconocer la importancia económica y social de la caña de azúcar posicionada como la principal agroindustria de la provincia con más de 5.000 productores y 15 ingenios que producen el 62\% del azúcar del país. También, el impacto ambiental que tiene la actividad con la utilización de la quema durante la cosecha y poscosecha del cultivo, lo cual genera fuertes presiones de la sociedad.

Por eso, considerando que la Mesa de Gestión Ambiental de Cruz Alta trabaja para lograr la erradicación de esta práctica, continuamos nuestro análisis 
con la construcción de una realidad sobre la problemática de la quema en su contexto.

Así, comprendimos que durante el proceso de producción del cultivo el fuego es utilizado, desde 1960 aproximadamente, para eliminar las hojas que envuelven a la caña y otros residuos que quedan en el campo después de la cosecha, considerados basura. Esto se realiza para abaratar los costos de producción, además porque no existen alternativas tecnológicas viables o accesibles para que los productores puedan dejar de quemar, especialmente los de pequeña y mediana escala. A esto se suman las quemas accidentales o intencionadas por parte de personas ajenas a las explotaciones cañeras.

Pero, el problema radica en que esta práctica contamina la atmósfera y el suelo, causa problemas en la salud de la población, provoca daños en los tendidos eléctricos, ocasiona accidentes de tránsito e incendios en infraestructuras cercanas.

También, entendimos que si bien existe una legislación nacional y provincial que prohíbe la quema en el cultivo con sanciones administrativas y penales, esto por sí mismo no logró resolver la problemática.

Y, a pesar de que las instituciones de ciencia y técnica de la provincia están trabajando en el desarrollo de tecnologías que permitan evitar la quema, éstas aún se encuentran en etapa experimental o se desarrollan a una escala muy baja para brindar una solución a la totalidad del sector.

Dentro de ese contexto se gestó la organización sujeto de análisis de nuestra tesis en busca de la transformación de una práctica social y cultural, por lo que el siguiente paso de la investigación fue la realización de un pre-diagnóstico sobre la Mesa para conocer cómo se creó y quiénes son los sujetos que la integran, los cuales tienen su enfoque e intereses propios.

En un recorrido por la historicidad de la organización, comprendimos que el récord de fuegos sobre caña detectados en el año 2009 en Tucumán aumentó la presión de la sociedad y llevó a que el INTA Famaillá convocara a los actores vinculados a la quema para analizar la problemática y pensar cambios posibles.

De este modo, en mayo de 2010 quedó conformada la Mesa de Gestión Ambiental de Cruz, una organización interinstitucional y multidisciplinaria que reúne a representantes del INTA; las áreas de producción, medio ambiente, seguridad ciudadana, salud y educación del gobierno provincial; bomberos voluntarios; y 
organizaciones gremiales, cooperativas, grandes empresas y productores independientes del sector cañero.

En la descripción de cada representante de esas instituciones, visualizamos una diversidad de miradas, experiencias, capacidades, intereses y poderes, a veces complementarios y otros contrapuestos, de acuerdo a su vínculo con la quema de caña. $\mathrm{Y}$, desde esa especificidad, cada sujeto aportó sus conocimientos en la construcción del diagnóstico y en el diseño de las estrategias de la Mesa.

Esto nos permitió evaluar la viabilidad y factibilidad del diagnóstico comunicacional con el que continuamos en el cuarto capítulo de nuestra tesis. Mediante la descripción, análisis y valoración de las situaciones de comunicación de la organización pudimos conocer el proceso de elaboración y ejecución de la Propuesta de Programa de Erradicación Progresiva de la Quema de Caña de Azúcar en el Departamento, además de la construcción y difusión de los diferentes productos comunicacionales.

En el análisis del proceso transcurrido, reconocimos que, por momentos, la Mesa logró trabajar desde una perspectiva de la comunicación concebida como una instancia de puesta en común, donde la participación y la construcción conjunta fueron elementos indispensables. En este sentido, pudo llevar adelante un diagnóstico y diseñar un programa de forma participativa, con los debates y las decisiones consensuadas entre los integrantes. Del mismo modo que todos los actores de la organización hicieron sus aportes para la definición del contenido de los productos comunicacionales.

También, desde una concepción de la comunicación-educación basada en la construcción en común del conocimiento y no en la transmisión de saberes de un sujeto a otro, la Mesa logró diseñar una metodología participativa para trabajar en la reflexión colectiva sobre la problemática de la quema en las escuelas considerando la cultura, el contexto propio, las experiencias vividas, las relaciones sociales y el propio conocimiento local vinculado con la práctica de la quema de caña; además de proponer a los chicos como educadores de su comunidad con productos comunicacionales creados por ellos mismos. Esto da cuenta de una mirada de la educación como participación, creatividad, expresividad y relacionalidad, preocupada por "la interacción dialéctica entre las personas y su realidad, y el desarrollo de la capacidad y de la conciencia social” (Kaplún, 1978: 249). 
Sin embargo, al momento de evaluar el diseño y ejecución de las estrategias dentro del programa de erradicación, en general observamos la ausencia de una programación que defina los interlocutores; las modalidades de ejecución; las actividades o tareas que generarían los resultados esperados; los recursos económicos, humanos y materiales necesarios para llevarlo adelante; y un sistema de evaluación.

También, en algunos casos reconocimos una construcción de la comunicación basada en una racionalidad instrumental, "una matriz cuya linealidad y carácter instrumental puede cuestionarse desde otras perspectivas de comprensión de los hechos comunicativos" (Mata, 1994: 3). A esto nos referimos con la concepción de los productores de Cruz Alta como meros 'receptores' del plan de reducción de quema de cañaverales, sin crear espacios de reflexión y construcción que involucraran su participación.

Del mismo modo, la propuesta del plan de concientización menciona como objetivo instalar el tema en la sociedad local y movilizar la reflexión de la población, procurando un cambio de actitud. Esto da cuenta de paradigmas de la comunicación basados en el diseño de tecnologías para persuadir en lugar de educar, sin tomar en cuenta las condiciones sociales y culturales en las que la gente toma decisiones.

En este caso, la inexistencia de una programación que explicite metas, actividades y recursos necesarios para ejecutar los productos llevó a una falta de continuidad en la selección, producción, contenidos y ejecución de los mismos.

Relacionado a esto, vimos los problemas ocasionados por la falta de identificación previa de los espacios mediáticos potenciales para la difusión de información dentro del contexto de influencia de la organización con los medios más significativos para sus interlocutores. De allí las dificultades que tuvo la Mesa para difundir el compromiso de adhesión voluntaria destinado a los productores y el spot televiso y radial; además de que no logró una permanencia en los medios de comunicación para colocar su propuesta sobre la problemática de la quema en la agenda pública.

De la misma manera, los problemas para ejecutar el proyecto de educación junto a los agentes sanitarios se debieron a la ausencia de una planificación que defina las acciones o tareas concretas que generarían los resultados esperados y las condiciones de viabilidad y factibilidad para favorecer la realización del proyecto. 
También, a la falta de formación de todos los agentes sanitarios para involucrarlos y comprometerlos como capacitadores dentro del programa.

Llegamos, de esta manera, al final de la construcción del diagnóstico de los procesos comunicacionales desarrollados en la Mesa de Gestión Ambiental de Cruz Alta para proponer líneas de acción que permitan rediseñar las estrategias de la organización en el territorio desde una concepción de la planificación y gestión como proceso dinámico, complejo e integral que incluye las fases de diagnóstico, planificación, diseño de estrategias, ejecución y evaluación.

\section{Construcción de las propuestas de cambio}

Las líneas de acción propuestas en este apartado comenzaron a construirse en el "Taller de evaluación y construcción de las propuestas de cambio", realizado en dos etapas. La primera fue el 18 de octubre y la segunda el 20 de diciembre de 2012, ambas con la participación de todos los actores.

Las jornadas se realizaron en el lugar habitual de las reuniones de la Mesa, la sede de la Agencia de Extensión Rural Banda del Río Salí del INTA, considerando que permitía favorecer el intercambio en un ambiente reconocido y cotidiano para los participantes. Además, era el espacio adecuado para trabajar en un taller participativo, debido a que cuenta con una mesa ovalada con sillas alrededor para el trabajo en círculo, auspiciando la multiplicidad de miradas y la democratización de las voces.

La metodología utilizada para llevar adelante esta actividad fue la participativa, intercambiando los conocimientos de los actores. En este sentido, Daniel Prieto Castillo (1990: 54) afirma que:

Todo ser humano tiene conocimientos válidos para enfrentar la situación que le toca vivir. En ese sentido, nadie es totalmente ignorante, hay una sabiduría de la vida cotidiana, producto de acumulación de experiencias, de la confrontación con las condiciones de existencia. Se trata de una sabiduría algunas veces más válida que las propuestas teóricas. Pero ello no es suficiente para enfrentar todo. En este sentido, la gente sabe y no sabe, está preparada para algunas situaciones y carece de la información y experiencias necesarias para enfrentar otras. 


\section{Etapa 1. Debilidades y fortalezas}

Durante la primera jornada, realizada el 18 de octubre del 2012, el taller estuvo centrado en la evaluación de las dificultades y los logros que tuvo la Mesa con el diseño y ejecución del Programa de erradicación progresiva de la quema de caña de azúcar en el departamento Cruz Alta.

Entendemos que la finalidad de todo proceso de evaluación es saber cuáles son los efectos que las acciones planificadas promueven en la realidad de la organización y en su contexto. Por eso, "la evaluación no es un fin en sí mismo. Su valor reside en la comunicación de los resultados y de las conclusiones para que puedan ser utilizados por la propia organización para mejorar la calidad de sus propuestas y servicios, la pertinencia de su planificación y, de esta manera, alcanzar de manera más acabada la misión que le es propia” (Villamayor, 2002: 78).

Los objetivos que nos planteamos para la primera etapa del taller fueron los siguientes:

- Compartir la recuperación histórica del proceso de construcción y ejecución del Programa de erradicación progresiva de la quema de caña de azúcar en el departamento Cruz Alta durante los tres años que duró en el territorio (2010-2012).

- Reflexionar sobre el proceso transcurrido para evaluar las dificultades y los logros alcanzados en el trabajo con los productores y la sociedad.

- Sistematizar debilidades y fortalezas a partir de los problemas y oportunidades identificados por los actores.

Para la concreción de estos objetivos nos propusimos una serie de actividades que exponemos a continuación:

1. Presentación de la historicidad de la Mesa.

2. Identificación de las dificultades y logros del programa creado por la organización.

3. Plenario colectivo sobre las reflexiones del grupo. 
4. Sistematización de debilidades y fortalezas a partir de las propuestas de los actores.

Las coordinadoras de la jornada fuimos Cristina Biaggi y yo, que iniciamos el taller con la primera actividad de la jornada. La misma consistió en una presentación, utilizando como soporte el Power Point, sobre las distintas partes de la construcción y ejecución del Programa de erradicación progresiva de la quema de caña de azúcar en el departamento Cruz Alta.

Parte 1: Diagnóstico sobre la problemática de la quema. En esta parte se recuperaron las demandas construidas por los actores en las dos primeras reuniones (2010).

Parte 2: Compromiso ${ }^{52}$ de adhesión voluntaria para los productores. En el trabajo de la Mesa con los productores se revisó el texto del documento, la difusión del mismo, la baja adhesión de los productores y el rechazo de la Secretaría de Medio Ambiente.

Parte 3: Concientización sobre la problemática de la quema. En este punto se hizo un repaso por la difusión de los afiches, spots y comunicados de prensa.

Parte 4: Mediación pedagógica en las escuelas. La última parte se focalizó en los avances y dificultades de ejecución del plan con los agentes sanitarios. Para ello se recuperaron las demandas surgidas en el taller de seguimiento y evaluación realizado con los 13 supervisores el 16 de agosto de 2011.

Durante la presentación se dejó abierta la posibilidad de que los actores intervinieran con opiniones o sugerencias, ofreciendo un espacio constante de diálogo entre los participantes.

Para la segunda actividad, encadenada a la primera, la propuesta fue trabajar en un solo grupo conformado por la totalidad de los actores, considerando que todos tuvieron alguna participación en las actividades de la Mesa y, por lo tanto, era importante que aportaran su visión sobre el proceso transcurrido para la

\footnotetext{
${ }^{52}$ Nos referimos al "Compromiso de adhesión voluntaria al programa piloto de erradicación de la quema de caña de azúcar en el departamento Cruz Alta, Tucumán" diseñado dentro del Plan de reducción de quema de cañaverales.
} 
discusión. La consigna fue analizar e interpretar la experiencia de la organización para identificar:

Consigna 1: Logros y dificultades del Plan de reducción de quema de cañaverales destinado a los productores.

Consigna 2: Logros y dificultades del Plan de concientización/educación dirigido a la sociedad civil.

Las ideas surgidas en cada actor fueron discutidas con el resto de los participantes. A continuación transcribimos las propuestas que quedaron plasmadas en una pizarra y fueron compartidas en el plenario final.

\section{Consigna 1:}

\section{Dificultades:}

- Los productores no adhirieron al compromiso porque:

- Las estrategias de difusión fueron insuficientes o inadecuadas.

- El procedimiento detallado para realizar una quema controlada se consideró engorroso e inviable.

- Existe una negación por parte de los productores para inscribirse en el "Registro de Productores Cañeros".

- La presión de la sociedad civil fue la que impidió que los funcionarios aceptaran un protocolo de erradicación progresiva con quema controlada.

- El gobierno no toma la decisión política de resolver la problemática.

- La negación de la industria azucarera de participar en la Mesa dificultó el proceso de cambio impulsado por la organización.

- No se logró ofrecer alternativas para atender otras de las demandas surgidas en el diagnóstico como:

- La quema de maloja después de la cosecha.

- La situación de los medianos y grandes productores que por problemas de superficie deben quemar la caña. 
- No se trabajó sobre la concientización de los productores para que empiecen a dejar de quemar.

\section{Logros:}

- En los campos de los productores participantes de la Mesa se observa:

- Reducción de la quema de caña en pie.

- Avances en el porcentaje de cañaverales con manejo en verde.

- Importante mejora de las prácticas culturales para evitar incendios. Por ejemplo, la limpieza de callejones que funciona como cortafuego.

- Mayor inversión de los establecimientos más grandes para la puesta en funcionamiento de mecanismos para evitar incendios.

\section{Consigna 2:}

\section{Dificultades:}

- Hubo fallas en los mecanismos de difusión de los productos comunicacionales.

- La Mesa tuvo una baja aparición en los medios de comunicación.

- Hubo dificultades en el funcionamiento del plan con los agentes sanitarios por:

- Falta de programación previa para implementar el plan.

- Falta de formación del total de agentes sanitarios (290) como capacitadores.

\section{Logros:}

- La Mesa logró visibilidad pública al ser invitada por la Defensoría del Pueblo y la Legislatura de Tucumán para presentar su propuesta.

- Se elaboraron productos comunicacionales como afiches, spots, video, folletos.

- Se diseñó una metodología participativa para trabajar con los chicos de las escuelas.

- La estrategia de mediación pedagógica en las escuelas permitió que 3.395 chicos reflexionaran sobre la problemática de la quema, movilizándolos como educadores de sus familias y comunidad. 
La sistematización de la primera etapa del taller se realizó partiendo de la identificación de debilidades y fortalezas. Siguiendo la propuesta de Claudia Villamayor (2002: 48), entendemos que "la distancia entre una situación dada y una deseada, considerada esta última como óptima, constituye una debilidad. De esta manera las debilidades comprenden una dimensión objetiva (la referencia a la situación dada) y una dimensión subjetiva (el patrón de deseabilidad establecido por el sujeto)". En cuanto a las fortalezas, la misma autora (2002: 49) las considera como "hechos, situaciones, capacidades, logros, etc., considerados positivos para la gestión, para el cumplimiento de su misión y su visión".

A partir de las reflexiones de los actores sobre el proceso transcurrido, las coordinadoras elaboramos una matriz de datos en la que identificamos las dificultades y logros propuestos como debilidades y fortalezas de la organización, caracterizándolas de acuerdo al origen de cada una: organizacional (vinculadas a la gestión de la organización) o contextual/estructural (asociadas al contexto o a procesos macro-sociales). Esto nos permitiría evaluar las posibilidades reales de la Mesa para intervenir sobre ellas.

En el siguiente cuadro se visualiza la matriz de datos elaborada, que sirvió como insumo para que los actores identificaran los nudos críticos y las posibles líneas de acción para el cambio en la siguiente etapa del taller.

\begin{tabular}{|c|c|c|c|c|}
\hline \multirow{5}{*}{$\begin{array}{l}\text { Plan de } \\
\text { reducción de } \\
\text { quema de } \\
\text { cañaverales } \\
\text { (Productores) }\end{array}$} & \multirow{5}{*}{ Debilidades } & \multirow{3}{*}{$\begin{array}{l}\text { Falta de adhesión de } \\
\text { los productores al } \\
\text { compromiso }\end{array}$} & $\begin{array}{l}\text { Estrategias de difusión } \\
\text { insuficientes o inadecuadas }\end{array}$ & $\begin{array}{c}\text { Origen } \\
\text { Organizacional }\end{array}$ \\
\hline & & & $\begin{array}{l}\text { Procedimiento de quema } \\
\text { controlada engorroso e } \\
\text { inviable. }\end{array}$ & $\begin{array}{c}\text { Origen } \\
\text { Organizacional }\end{array}$ \\
\hline & & & $\begin{array}{l}\text { Negación de los } \\
\text { productores para inscribirse } \\
\text { en el "Registro de } \\
\text { Productores Cañeros". }\end{array}$ & $\begin{array}{l}\text { Origen } \\
\text { Contextual/ } \\
\text { Estructural }\end{array}$ \\
\hline & & $\begin{array}{l}\text { Falta de aprobación } \\
\text { del compromiso por } \\
\text { parte de los } \\
\text { funcionarios }\end{array}$ & & $\begin{array}{l}\text { Origen } \\
\text { Contextual/ } \\
\text { Estructural }\end{array}$ \\
\hline & & $\begin{array}{c}\text { Falta de decisión } \\
\text { política para resolver } \\
\text { la problemática }\end{array}$ & & $\begin{array}{l}\text { Origen } \\
\text { Contextual/ } \\
\text { Estructural }\end{array}$ \\
\hline
\end{tabular}




\begin{tabular}{|c|c|c|c|c|}
\hline & & $\begin{array}{c}\text { Negación de la } \\
\text { industria azucarera } \\
\text { para participar de la } \\
\text { Mesa }\end{array}$ & & $\begin{array}{l}\text { Origen } \\
\text { Contextual/ } \\
\text { Estructural }\end{array}$ \\
\hline & & $\begin{array}{l}\text { Falta de estrategias } \\
\text { de concientización } \\
\text { para los productores }\end{array}$ & & $\begin{array}{c}\text { Origen } \\
\text { Organizacional }\end{array}$ \\
\hline & & $\begin{array}{l}\text { Falta de oferta de } \\
\text { alternativas para }\end{array}$ & $\begin{array}{l}\text { Quema de maloja después } \\
\text { de la cosecha. }\end{array}$ & $\begin{array}{l}\text { Origen } \\
\text { Contextual/ } \\
\text { Estructural }\end{array}$ \\
\hline & & $\begin{array}{l}\text { otras demandas } \\
\text { surgidas en el } \\
\text { diagnóstico }\end{array}$ & $\begin{array}{l}\text { Quema de caña por } \\
\text { problemas de superficie en } \\
\text { medianos y grandes } \\
\text { productores. }\end{array}$ & $\begin{array}{l}\text { Origen } \\
\text { Contextual/ } \\
\text { Estructural }\end{array}$ \\
\hline & & & $\begin{array}{l}\text { Reducción de quema de } \\
\text { caña en pie. }\end{array}$ & $\begin{array}{c}\text { Origen } \\
\text { Organizacional }\end{array}$ \\
\hline & & $\begin{array}{l}\text { Transformaciones en } \\
\text { las prácticas de los }\end{array}$ & $\begin{array}{l}\text { Avances en el porcentaje } \\
\text { de cañaverales con manejo } \\
\text { en verde. }\end{array}$ & $\begin{array}{c}\text { Origen } \\
\text { Organizacional }\end{array}$ \\
\hline & Fortalezas & $\begin{array}{c}\text { productores } \\
\text { participantes de la } \\
\text { Mesa }\end{array}$ & $\begin{array}{l}\text { Importante mejora de las } \\
\text { prácticas culturales para } \\
\text { evitar incendios. }\end{array}$ & $\begin{array}{c}\text { Origen } \\
\text { Organizacional }\end{array}$ \\
\hline & & & $\begin{array}{l}\text { Mayor inversión de las } \\
\text { empresas en mecanismos } \\
\text { para evitar incendios. }\end{array}$ & $\begin{array}{c}\text { Origen } \\
\text { Organizacional }\end{array}$ \\
\hline & & $\begin{array}{l}\text { Fallas en los } \\
\text { mecanismos de } \\
\text { difusión de los } \\
\text { productos } \\
\text { comunicacionales }\end{array}$ & & $\begin{array}{c}\text { Origen } \\
\text { Organizacional }\end{array}$ \\
\hline $\begin{array}{c}\text { Plan de } \\
\text { concientización } \\
\text { / educación } \\
\text { (sociedad) }\end{array}$ & Debilidades & $\begin{array}{c}\text { Baja aparición en los } \\
\text { medios de } \\
\text { comunicación } \\
\text { masiva }\end{array}$ & & $\begin{array}{c}\text { Origen } \\
\text { Organizacional }\end{array}$ \\
\hline & & $\begin{array}{l}\text { Dificultades en el } \\
\text { funcionamiento del }\end{array}$ & $\begin{array}{l}\text { Falta de planificación del } \\
\text { proceso de implementación } \\
\text { del plan. }\end{array}$ & $\begin{array}{c}\text { Origen } \\
\text { Organizacional }\end{array}$ \\
\hline & & $\begin{array}{c}\text { plan con los agentes } \\
\text { sanitarios }\end{array}$ & $\begin{array}{l}\text { Falta de formación del total } \\
\text { de agentes sanitarios como } \\
\text { capacitadores. }\end{array}$ & $\begin{array}{c}\text { Origen } \\
\text { Organizacional }\end{array}$ \\
\hline
\end{tabular}




\begin{tabular}{|c|c|c|}
\hline \multirow{4}{*}{ Fortalezas } & $\begin{array}{c}\text { Productos } \\
\text { comunicacionales } \\
\text { elaborados }\end{array}$ & $\begin{array}{c}\text { Origen } \\
\text { Organizacional }\end{array}$ \\
\hline & $\begin{array}{c}\text { Metodología de } \\
\text { trabajo participativa } \\
\text { en las escuelas }\end{array}$ & $\begin{array}{c}\text { Origen } \\
\text { Organizacional }\end{array}$ \\
\hline & $\begin{array}{l}\text { Reconocimiento/Visi } \\
\text { bilidad en el ámbito } \\
\text { público }\end{array}$ & $\begin{array}{c}\text { Origen } \\
\text { Organizacional }\end{array}$ \\
\hline & $\begin{array}{l}\text { Movilización para la } \\
\text { reflexión y acción } \\
\text { sobre la } \\
\text { problemática en las } \\
\text { escuelas }\end{array}$ & $\begin{array}{c}\text { Origen } \\
\text { Organizacional }\end{array}$ \\
\hline
\end{tabular}

Los datos expresados en el cuadro muestran que las debilidades del plan destinado a los productores son mayormente de origen contextual/estructural, mostrando una mayor dificultad para operar sobre ellas, debido a que no se encuentran dentro del campo de intervención directa de la organización. A diferencia de ello, la totalidad de las fortalezas y debilidades del plan dirigido a la sociedad se vinculan con los niveles de gestión y la cultura organizacional de la Mesa, resultando más factible la intervención en ellas a partir de la definición de líneas de acción.

\section{Etapa 2. Líneas de acción propuestas}

La segunda etapa del taller estuvo centrada en proponer líneas de acción como respuestas a las debilidades y fortalezas identificadas en la jornada anterior, a fin de rediseñar las estrategias de la Mesa de Gestión Ambiental de Cruz Alta.

Los objetivos que nos planteamos para concluir con el taller fueron los siguientes:

- Compartir la matriz de datos de debilidades y fortalezas caracterizadas de acuerdo a su origen organizacional o contextual/estructural. 
- Identificar los nudos críticos sobre los que se pudieran planificar procesos de cambio.

- Proponer líneas de acción que permitan la transformación del proyecto de la Mesa.

Nos referimos a la identificación de un nudo crítico entendido como "una situación que de ser modificada generará procesos de transformación que impactarán de manera relevante en el ámbito objeto de nuestra preocupación y que queremos cambiar. Entendemos por nudos críticos aquellas cuestiones que aparecen de manera recurrente, son determinantes de peso de las brechas dentro del mapa causal y están dentro de nuestro campo de actuación. Pueden entenderse también como problemas coincidentes que son, a su vez, causa común de otras situaciones problemáticas" (Uranga, 2008: 42).

Estos nudos críticos deben ser relevantes, determinantes de mayor peso y pertinentes, es decir, encontrarse dentro del campo de intervención posible de la organización. Con esto nos referimos a considerar si la organización tiene los recursos físicos y económicos y las capacidades operativas y organizacionales para enfrentarlos.

La concreción de estos objetivos se llevó adelante mediante una serie de actividades que planteamos a continuación:

1. Presentación de la matriz de datos de debilidades y fortalezas.

2. Identificación de los nudos críticos.

3. Propuesta de líneas de acción en respuesta a los nudos críticos identificados.

4. Plenario colectivo sobre las reflexiones del grupo.

5. Sistematización del taller.

La primera actividad fue la exposición de la matriz de debilidades y fortalezas ante los actores de la Mesa, a cargo de las coordinadoras del taller.

Encadenada a la primera se dio la segunda actividad de la jornada. La consigna fue identificar cuáles de esas debilidades o fortalezas podrían ser 
consideradas nudos críticos, es decir, factibles de ser abordadas por la organización para convertirse en futuras líneas de acción.

La dinámica de trabajo fue un debate donde los participantes dialogaron sobre las situaciones en las que podría intervenir la Mesa de Gestión para superar las dificultades que tuvo el programa de erradicación en los tres años de ejecución en el territorio. Finalmente, las propuestas quedaron plasmadas en una pizarra.

A continuación, transcribimos los nudos críticos seleccionados por los actores como disparadores de las posibles líneas de acción en el trabajo con los productores. También analizamos algunas claves surgidas durante la discusión que nos permitirán comprender la elección de los nudos y las propuestas construidas en la siguiente actividad.

- Falta de oferta de alternativas para la quema de maloja después de la cosecha.

- Falta de estrategias de concientización para los productores.

En este caso, el proceso de intercambio de opiniones entre los actores estuvo centrado en problematizar el rol del poder político-estatal en las acciones de la Mesa.

En este sentido consideraron que la mayor limitante para implementar el plan de reducción progresiva de la quema dentro de las excepciones de la ley fue el rechazo del compromiso por parte de la Secretaría de Medio Ambiente y la falta de decisión política del gobierno provincial de resolver la problemática en general. Por lo tanto, plantearon que no era posible abordar las debilidades asociadas al contexto e insistir en rediseñar una propuesta de quema controlada con erradicación progresiva que requiera de la aprobación de un organismo gubernamental.

A partir de las limitaciones reconocidas en el contexto político de la Mesa, los actores propusieron orientar las nuevas acciones hacia el trabajo con los productores y el desarrollo de las alternativas tecnológicas para el aprovechamiento de la maloja, que era lo que estaba al alcance de la intervención directa de la organización.

Las condiciones de viabilidad y factibilidad de estos nudos críticos se basaron en la fortaleza identificada en el diagnóstico donde que se reconoce que 
hubo transformaciones en las prácticas de los productores de la Mesa. También en los desarrollos tecnológicos que viene realizando el INTA como la producción de briquetas de carbón y ladrillos a partir de la maloja, que expusimos en el segundo capítulo de la tesis.

Con respecto a los nudos críticos para el rediseño del plan destinado a la sociedad, la Mesa tomó todas las debilidades identificadas en la matriz de datos:

- Fallas en los mecanismos de difusión de los productos comunicacionales elaborados.

- Baja aparición de la Mesa en los medios de comunicación.

- Falta de planificación del proceso de implementación del plan con los agentes sanitarios.

- Falta de formación del total de agentes sanitarios como capacitadores.

En la discusión sobre las debilidades o fortalezas que podrían ser abordadas por la Mesa para rediseñar el trabajo con la sociedad, la clave fue la problematización sobre la falta de planificación en las estrategias de la Mesa.

En esta construcción, sin profundizar demasiado en el tema, los actores tuvieron una aproximación al concepto de planificación entendida como "un método de acción sistemático destinado a producir un cambio en el rumbo de los acontecimientos, a partir de las conclusiones del diagnóstico y apuntando a un objetivo de cambio establecido conjuntamente por los actores de la organización" (Villamayor, 2002: 58).

En este sentido, reconocieron que parte de las debilidades del cuadro se debían a la ausencia de una programación previa de las actividades, lo cual dependía de la gestión de la organización y, por lo tanto, era pertinente para la acción inmediata.

En referencia a esto mencionaron que los spots no se publicaron porque previamente no se tuvieron en cuenta los fondos necesarios ni los medios y responsables de la difusión. También reconocieron la falta de programación para las actividades del plan con los agentes sanitarios, lo que derivó en las dificultades que 
hubo en la implementación de la propuesta; además de la ausencia de formación de los agentes sanitarios como capacitadores.

Sin embargo, en el análisis no llegaron a reconocer la falta de planificación para la difusión de información en los medios de comunicación.

Al evaluar las capacidades que tenía la Mesa para abordar estos nudos críticos, los actores destacaron el hecho de contar productos comunicacionales elaborados y una metodología participativa diseñada para trabajar en las escuelas.

La última actividad de la jornada tuvo la consigna de proponer una o varias líneas de acción como respuestas a los nudos críticos identificados. Del debate realizado entre los integrantes de la Mesa surgieron las siguientes propuestas, que fueron compartidas en el plenario final.

Nudo crítico 1: Falta de oferta de alternativas para la quema de maloja después de la cosecha.

Propuesta:

- Realizar módulos demostrativos sobre las alternativas de valorización de la maloja desarrolladas por el INTA en los campos de los productores.

Esta propuesta se relaciona con la necesidad de ofrecer alternativas tecnológicas que permitan darle un valor económico a los residuos agrícolas de cosecha (RAC) que quedan en el campo después de la recolección mecanizada, lo que ayudaría a disminuir las quemas. Recordemos que más del $80 \%$ de los cañeros quema la maloja, ya que sólo un pequeño porcentaje de los grandes productores cuenta con la maquinaria necesaria para no hacerlo. "Tucumán dispone de 3.600.000 toneladas de RAC disponibles, de las cuales se podría recolectar y utilizar el 50\%" (Fernández de Ullivarri, Vallejo y Valeiro, 2011: 71).

También es importante referir que las instituciones de ciencia y técnica de la provincia como el INTA y la EEAOC están desarrollando alternativas de uso, que aún no fueron adoptadas por los productores porque se encuentran en etapa experimental o se realizan a una baja escala. 
Esto da cuenta de la demanda explicitada por los actores de realizar módulos demostrativos donde los mismos productores puedan evaluar el uso de estas alternativas en sus campos.

Nudo crítico 2: Falta de estrategias de concientización para los productores.

Propuesta:

- Generar encuentros con los productores para analizar la problemática y las posibles estrategias de erradicación.

En este caso, la propuesta responde a la necesidad de involucrar a los productores en la reflexión sobre la problemática de la quema y en el diseño de las estrategias de transformación. Recordemos que en el caso del compromiso de adhesión voluntaria al programa de erradicación de la quema, la estrategia se limitó a difundir información sobre la propuesta de la Mesa y no a generar espacios de encuentro que involucren la participación de los productores. Esto generó dificultades para lograr la adhesión de los cañeros de Cruz Alta al compromiso. De allí la propuesta de generar encuentros con los productores, donde se visualiza una forma de comunicación basada en la participación de todos los actores para construir los conocimientos sobre su realidad y tomar decisiones.

Nudo crítico 3: Fallas en los mecanismos de difusión de los productos comunicacionales elaborados.

\section{Propuestas:}

- Realizar acuerdos de difusión con los principales medios para la publicación del spot televisivo y radial "Entre todos podemos cuidar nuestra provincia".

- Utilizar las redes sociales para difundir los productos e interactuar con los usuarios.

Con respecto a la difusión de los productos comunicacionales elaborados por la Mesa, los actores orientaron su propuesta a gestionar con los principales medios televisivos (Canal 10, Canal 8, Canal 5 y CCC) y radiales (Antena 8, LV12, LV7, 
Radio Universidad) de Tucumán la difusión de los spots, dado que son los de mayor alcance en toda la Provincia.

Por otra parte, propusieron la búsqueda de medios alternativos a los tradicionales como la radio y la televisión para socializar los spots, el video, los folletos y los comunicados de prensa. Entre ellos se mencionó el uso de Facebook como una manera gratuita de difundir sus productos y poder intercambiar opiniones con los usuarios, en referencia a la sociedad.

Nudo crítico 4: Baja aparición de la Mesa en los medios de comunicación masiva.

\section{Propuestas:}

- Evaluar los medios de comunicación más significativos para los pobladores y productores de Cruz Alta para difundir los comunicados de prensa.

- Difundir información sobre la importancia de la caña de azúcar para la provincia, las ventajas de la cosecha en verde, experiencias ejemplificadoras de productores que no queman, propuestas de valorización de la maloja, entre otras.

Como respuesta al nudo crítico, la propuesta hace referencia a la necesidad de identificar cuáles son los medios de comunicación que utilizan los ciudadanos de Cruz Alta para informarse, a fin de poder difundir la temática de interés de la Mesa específicamente en esos medios. A partir de ello, propone informar sobre los distintos aspectos de la problemática de la quema para instalar el tema en el ámbito público, considerado como "un escenario complejo, multisectorial y multiactoral, donde se visibilizan los intereses, las demandas, las necesidades, los proyectos políticos, las relaciones de poder y las alianzas de estos mismos actores. El espacio público es el escenario de la acción" (Uranga, 2008: 11).

Nudo crítico 5: Falta de planificación del proceso de implementación del plan con los agentes sanitarios.

\section{Propuesta:}

- Programar las actividades a desarrollar en el plan con los agentes sanitarios: objetivos, responsables, resultados esperados, materiales, herramientas para reproducir los materiales. 
Esta propuesta respondió a las dificultades planteadas por los agentes sanitarios para implementar el plan diseñado en el año 2011. Recordemos que en el taller de seguimiento y evaluación realizado el 16 de agosto de ese año se destacó la falta de medios de movilidad para trasladarse a las escuelas, problemas para reproducir el video por falta de reproductores de DVD, falta de personal y disponibilidad horaria de los agentes para cumplir con las metas previstas, falta de videos y folletos para entregar, problemas con los directores para realizar los talleres. Esto da cuenta de la ausencia de una planificación previa que permita programar objetivos, metas, interlocutores, responsables, modalidades de ejecución, calendarización de actividades, resultados esperados, insumos y presupuestos, viabilidad y factibilidad, sistema de evaluación.

Nudo crítico 6: Falta de formación del total de agentes sanitarios como capacitadores.

\section{Propuestas:}

- Educar a los agentes sanitarios sobre la complejidad de la problemática de la quema.

- Capacitarlos sobre herramientas participativas.

En este caso, los actores plantearon la necesidad de informar a los agentes sanitarios sobre la complejidad de la problemática de la quema. Por otro lado, propusieron repetir el curso sobre herramientas participativas para el abordaje comunitario, que se había realizado con los 13 supervisores de áreas operativas, ampliándolo para la totalidad de los agentes participantes del plan.

La sistematización del taller se hizo a partir del reconocimiento de las marcas de racionalidad en una situación de comunicación. La perspectiva desarrollada por Sandra Massoni (2007: 118) plantea que "cada teoría opera distintas dimensiones del fenómeno comunicacional, y al hacerlo le imprime su racionalidad, su proyecto. Es posible interpelar situaciones de comunicación para rastrear estas marcas de racionalidad, que son índices de la concepción teórica que está organizando, articulando la matriz del encuentro". 
Como veremos, las marcas de racionalidad que propone la autora se relacionan con diferentes perspectivas de la comunicación que van desde el registro instrumental-difusionista al procesual, situacional e histórico.

Para llevar adelante este análisis partimos de claves comunicacionales entendidas como ideas o conceptos que estructuran y explican el desarrollo de diferentes reflexiones surgidas del diagnóstico. Estas claves se pueden relacionar teóricamente con diferentes racionalidades dominantes, cumpliendo la función de entender estos núcleos de saberes elaborados. Por lo tanto, nos permiten ligar la teoría propuesta y la especificidad de la práctica social analizada, en este caso el programa de erradicación progresiva de la quema elaborado por la Mesa.

Entonces, rescatando las propuestas de los actores en el taller, se pueden nombrar tres claves comunicacionales que ayudarán a pensar en las líneas de acción para transformar los espacios de intervención de la Mesa en el territorio. Éstas son "Construcción de saberes", "Planificación de actividades" y "Difusión de información".

A continuación exponemos la matriz de datos elaborada que expresa la relación entre las propuestas para rediseñar el programa de la Mesa, las claves y las racionalidades dominantes.

\begin{tabular}{|c|c|c|}
\hline Clave comunicacional & Propuestas & $\begin{array}{l}\text { Características de la } \\
\text { racionalidad dominante }\end{array}$ \\
\hline Construcción de saberes & $\begin{array}{l}\text { - Realizar módulos } \\
\text { demostrativos. } \\
\text { - Generar encuentros con los } \\
\text { productores para analizar la } \\
\text { problemática y las posibles } \\
\text { estrategias de erradicación. } \\
\text { - Educar a los agentes } \\
\text { sanitarios sobre la complejidad } \\
\text { de la problemática de la } \\
\text { quema. } \\
\text { - Capacitar a los agentes } \\
\text { sobre herramientas } \\
\text { participativas. }\end{array}$ & $\begin{array}{c}\text { Interacción de sujetos } \\
\text { Heterogeneidad } \\
\text { Multiplicidad } \\
\text { Comunicación como articulación } \\
\text { de la diversidad social } \\
\text { Horizontalidad }\end{array}$ \\
\hline
\end{tabular}




\begin{tabular}{|c|c|c|}
\hline $\begin{array}{l}\text { Diagnóstico y Planificación de } \\
\text { la comunicación }\end{array}$ & $\begin{array}{l}\text { - Evaluar los medios de } \\
\text { comunicación más } \\
\text { significativos para los } \\
\text { pobladores y productores de } \\
\text { Cruz Alta para difundir los } \\
\text { comunicados de prensa. } \\
\text { - Programar las actividades a } \\
\text { desarrollar en el plan con los } \\
\text { agentes sanitarios. }\end{array}$ & Comunicación como proceso \\
\hline Difusión de información & $\begin{array}{l}\text { - Difundir información sobre } \\
\text { sobre la importancia de la } \\
\text { caña de azúcar para la } \\
\text { provincia... } \\
\text { - Realizar acuerdos de difusión } \\
\text { con los principales medios } \\
\text { para la publicación del spot. } \\
\text { - Utilizar las redes sociales } \\
\text { para difundir los productos e } \\
\text { interactuar con los usuarios. }\end{array}$ & $\begin{array}{c}\text { Linealidad } \\
\text { Verticalidad } \\
\text { Comunicación operativa }\end{array}$ \\
\hline
\end{tabular}

Esta vinculación da cuenta de cómo en la práctica social analizada en esta tesis operan distintas perspectivas comunicacionales. $\mathrm{Y}$, de esta manera, las propuestas de los actores nos permiten visualizar las posibilidades de operar sobre los problemas construidos a lo largo de esta investigación para rediseñar las estrategias de la Mesa desde una concepción de la comunicación como proceso complejo basado en la participación de los actores involucrados en un espacio social para construir saberes y tomar decisiones.

Para poder avanzar en la definición de las líneas de acción comunicacionales como aporte de este trabajo de investigación posgradual a la Mesa de Gestión será necesario identificar las tendencias de los nudos críticos y propuestas de los actores, consideradas como proyecciones hacia al futuro de las situaciones identificadas.

Entonces, considerando las debilidades y fortalezas identificadas y las propuestas correspondientes que, como vimos, reúnen las condiciones de viabilidad y factibilidad, podemos plantear dos tendencias. 
La primera sugiere que si la Mesa no genera las transformaciones propuestas como respuestas a los nudos críticos, no logrará comprometer a los productores para producir un cambio en sus prácticas. De este modo, los cañeros seguirán constituyéndose como meros receptores del plan de reducción de quema de cañaverales de la Mesa, sin ser partícipes del análisis y transformación de su realidad. Es posible proyectar, incluso, que la no inclusión de los productores en la construcción del cambio derive en una resistencia de los mismos para modificar sus prácticas productivas.

Por otra parte, de continuar la falta de un diagnóstico del mapa de medios de comunicación y una gestión de articulación con los mismos, es probable que la Mesa no logre consolidar la información de su interés en la agenda pública.

Lo mismo que la ausencia de planificación de las actividades a desarrollar en el plan de educación con los agentes sanitarios crea descoordinación de actividades y dificultades para el cumplimiento de las mismas.

En cambio, la segunda tendencia plantea que si la Mesa lleva adelante las transformaciones propuestas puede generar espacios de encuentro, diálogo y participación entre los productores cañeros del departamento Cruz Alta, posibilitando la construcción colectiva del cambio, a partir de reconocerse como sujetos capaces de expresarse, descubrir su respectiva realidad, construir conocimientos y tomar decisiones para resolver los problemas en los que se encuentran involucrados.

También, la incorporación de un diagnóstico de los medios de comunicación de mayor incidencia en Cruz Alta posibilitará la definición de estrategias de difusión adecuadas para sus productos. Del mismo modo que la planificación de las actividades en el plan de educación con los agentes sanitarios permitirá introducir cierta racionalidad y sistematicidad a las acciones y a la utilización de los recursos para alcanzar las metas deseadas. Teniendo en el horizonte siempre un cambio en pos de la sustentabilidad de los ambientes naturales y productivos en los que conviven no sólo personas sino también intereses, poderes y compromisos diversos.

A partir de evaluar las tendencias en la Mesa de Gestión Ambiental de Cruz Alta, proponemos las siguientes líneas de acción que, por el carácter de nuestra implicación, son comunicacionales. Éstas se formularon como respuestas a los aspectos comunicacionales identificados en los nudos críticos y propuestas de los 
actores, considerando además las condiciones organizacionales y contextuales/estructurales favorables de la organización.

Recordemos que las líneas de acción "son orientaciones de carácter general y expresan la voluntad de operar sobre aquellos niveles o aspectos que están bajo el control de la organización" (Uranga, 2008: 44).

- Auspiciar la realización de espacios de encuentro con los productores para socializar los avances alcanzados en los módulos demostrativos de valorización de la maloja e intercambiar experiencias.

- Crear talleres participativos con los productores de Cruz Alta para reflexionar sobre la problemática y diseñar las estrategias de transformación.

- Realizar un diagnóstico sobre los medios de comunicación existentes y los interlocutores de la organización para poder planificar estrategias adecuadas de difusión.

- Promover la planificación del plan de educación con los agentes sanitarios para ajustar necesidades y objetivos.

- Crear espacios de formación de los agentes sanitarios como capacitadores sobre la problemática de la quema para lograr la socialización de saberes y la construcción de herramientas participativas para el trabajo en las escuelas.

Estas líneas de acción propuestas son consideradas puntos de partida para rediseñar las estrategias de la Mesa en el territorio y poder alcanzar el futuro de transformación deseado. Por lo tanto, se expresan de manera general y sin la precisión que exigirá la planificación posterior, actividad que excede los límites de este trabajo de investigación posgradual y que se convertirá en el desafío para la organización de ahora en adelante.

La planificación y gestión de procesos comunicacionales en la Mesa de Gestión Ambiental de Cruz Alta comenzó a construirse con el diagnóstico realizado en esta tesis. Ahora resta continuar este proceso dinámico, complejo e integral que incluye además la planificación, el diseño de estrategias, la ejecución y la evaluación como fases que por momentos se desarrollan de manera simultánea y otras, transversalmente. Una propuesta que seguirá siendo dialógica y priorizará la 
participación del colectivo de actores durante todo el proceso de construcción y toma de decisiones en las diferentes etapas.

Nos referimos a la tarea que tendrá la Mesa de llevar adelante una planificación desde la comunicación entendida como una "herramienta eficaz para armonizar propósitos que se apoyen en objetivos políticos y sociales de transformación, tomando en cuenta todos los elementos del escenario en el que los mismos deben concretarse y desarrollando la manera de implementarlos de manera eficaz para generar alternativas positivas" (Uranga, 2001: 34). Esto implica trabajar en la definición de objetivos, metas y resultados esperados, criterios de acción, programación de las actividades, calendarización y un sistema de evaluación.

Para hacerlo, la organización deberá disponer de los recursos físicos y económicos y las capacidades necesarias, además de la voluntad política de cada una de las instituciones/organizaciones participantes. Por esto, creemos que una de las mayores limitantes para llevar adelante esta propuesta radica en la presencia de una sola comunicadora dentro de la organización. El desafío de planificar talleres participativos y espacios de encuentro con los productores de Cruz Alta; trabajar en un diagnóstico de los medios e interlocutores de la organización; planificar el plan de educación con los agentes sanitarios; y formar a los agentes como capacitadores exige la conformación de un equipo de comunicación que pueda conducir la planificación y gestión de los procesos comunicacionales propuestos junto a los integrantes de la Mesa y a los actores con los que se vincula o podrá vincularse.

Hablamos de un equipo constituido como un articulador de los diferentes sujetos sociales en las prácticas, a partir del reconocimiento de los saberes presentes en los protagonistas de cada espacio social y la participación de los grupos e instituciones relacionadas con el problema, sus condiciones y efectos. En palabras de Washington Uranga (2008: 6), el planificador de procesos comunicacionales es entendido como "aquel comunicador que trabaja en la articulación productiva de saberes y capacidades de estos distintos actores en función de la construcción de consensos en escenarios de transformación".

En el mismo sentido, Sandra Massoni habla de comunicadores con capacidad para llevar adelante un proceso de investigación acción en el abordaje de la diversidad sociocultural. "La tarea del comunicador al reconocer esta diversidad es indagar los posibles puntos de articulación de las diferencias en función de 
intereses y necesidades de grupos sociales que se reconocen como bien distintos, para operar desde allí en relación a un objetivo" (Massoni, 2007: 59).

Esto se convierte en fundamental porque las líneas de acción propuestas en esta tesis se orientan a rediseñar las estrategias de la Mesa para introducir sistematización en la planificación de las actividades e incluir la participación de los productores y la sociedad en la reflexión sobre la problemática de la quema y la construcción de compromisos para las propuestas de cambio. Como propone Frank Gerase (2008: 128), "cualquier programa que pretende tocar la vida del pueblo, en mayor o menor grado, sea programa gubernamental o voluntario, maneja la materia prima de las experiencias vividas del pueblo. No se trata de cifras, de estadísticas, sino de la vida. Para no falsear estos programas se necesita la participación del pueblo en su investigación, planificación y ejecución”.

Por último, quisiera concluir con una reflexión final sobre el significado que tuvo para mí este proceso de investigación científica, donde todos los actores conjugamos el doble rol de integrantes de la Mesa e investigadores, de sujetos conocedores y sujetos conocidos, transformándonos en la construcción permanente de ese conocimiento. Como plantea Varela (1996: 90), "el fenómeno de la interpretación se entiende aquí como la actividad circular que eslabona la acción y el conocimiento, al conocedor y lo conocido en un círculo indisociable".

De este modo, los actores iniciamos el camino de construcción de un proyecto para erradicar la quema en el año 2010, aportando nuestras miradas, conocimientos y propuestas desde las experiencias personales, los roles institucionales, los intereses y las capacidades profesionales o de oficio de cada uno en vínculo con la quema de caña. Este proceso se materializó en una serie de prácticas en el territorio provincial donde la Mesa como entidad desplegó acciones y productos comunicacionales, articulando con otros sujetos, en la búsqueda de una transformación social en beneficio de una convivencia sustentable.

Finalmente, al cumplirse los tres años previstos para el desarrollo del proyecto, los actores tuvimos que reconocer nuestros propios errores y aciertos, identificados como debilidades y fortalezas sobre las cuales proyectar cambios que permitan rediseñar las estrategias, además de sostener a la Mesa como organización interinstitucional y multidisciplinaria.

En ese largo proceso se fueron conjugando percepciones, sensaciones, deseos, sentimientos, sueños que dotaron de los rasgos constitutivos a la identidad 
de la organización, a la vez que posibilitaron la creación de vínculos personales y grupales entre los integrantes, transformando nuestras miradas, intereses y discursos en una constante recreación. Asimismo, se consolidó un grupo de trabajo, esto es innegable y destacable como proceso de transformación, que tal vez excedió los objetivos y las intenciones iniciales.

Desde lo personal, el mayor desafío en esta propuesta epistemológica de intervención social y política fue analizar crítica y valorativamente las prácticas de una organización en las cuales intervine activamente para su diseño y ejecución. Esto me llevó a someter a continuo análisis, e incluso cuestionar mi propio legado subjetivo (historia personal, experiencias de comunicación anteriores, visiones del mundo), los marcos teórico-metodológicos utilizados y las concepciones y acciones que tuvimos todos como actores durante la historicidad de la Mesa de Gestión Ambiental de Cruz Alta, que aún continúa desarrollándose. 
ALFARO, R. M. (2006) Otra brújula. Innovaciones en comunicación y desarrollo. Lima: Ed. Calandria.

ANDER-EGG, E. (2000) Métodos y técnicas de investigación social. Cómo organizar el trabajo de investigación. Vol. 3. Buenos Aires-México: Grupo Editorial Lumen Humanitas.

ANSCHAU, A. SOPENA, R. BENEDETTI, P. Y VALEIRO, A. (2011) Evaluación del potencial de generación de energía a partir del residuo de cosecha de la caña de azúcar en la provincia de Tucumán. Revista Ciencia y Tecnología de los Cultivos Industriales. Caña de azúcar, 1 (1), pp. 45-48.

ASOCIACIÓN DE CULTIVADORES DE CAÑA DE AZÚCAR. (2004) Manual de procedimiento para efectuar una quema. Cosecha y poscosecha. Cali: Autor.

BARBERO, J. M. (1987) Procesos de comunicación y matrices de cultura. Itinerario para salir de la razón dualista. México: FELAFACS-Gustavo Gilli.

BARRIONUEVO, M. A.; HIDALGO, M. Y MEONI, G. S. (1993) La zafra azucarera y su aporte a la contaminación atmosférica. Ciencia Médica, 8 (1) enero-febrero, pp 22-9.

BENEDETTI, P. Y VALEIRO, A. (2011) Seguimiento de quemas de cañaverales en Tucumán a través de sensores remotos durante el año 2009. Revista Ciencia y Tecnología de los Cultivos Industriales. Caña de azúcar, 1 (1), pp. 64-67.

BIAGGI, C. Y VALEIRO, A. (2012) Problemas ambientales, oportunidades de desarrollo territorial. Ponencia presentada al Encuentro Territorios en Movimiento. Quito. 5-7 junio 2012.

BUSCHIAZZO, M. (2009) Diagnóstico Comunicacional en la EEA Sáenz Peña INTA. Tesis de Maestría PLANGESCO, FPyCS-UNLP. La Plata.

BONGIOVANNI, R. Y GILETTA, M. (2012) Competitividad y calidad de los cultivos industriales: algodón, caña de azúcar, mandioca, maní, tabaco, té y yerba mate. En R. Bongiovanni, J. Morandi y L. Troilo eds. Competitividad y calidad de los cultivos industriales: algodón, caña de azúcar, mandioca, maní, tabaco, té y yerba mate. Córdoba: Ediciones INTA, pp. 1-9.

COMITÉ DE LA ASAMBLEA DE LA SALUD AMBIENTAL Y OCUPACIONAL DE LA SOCIEDAD TORÁCICA AMERICANA. (1996) Los efectos de la contaminación del aire exterior. Parte 2. American Journal de Medicina Respiratoria y Cuidados Críticos, 153 (2), febrero, pp. 477-98.

DíAZ BORDENAVE, J. (2007) Los pioneros. En S. Massoni y G. Torres coords. Seminario Internacional Comunicación y Desarrollo: encuentros en la diversidad, 21 de noviembre de 2007. Ciudad Autónoma de Buenos Aires. Buenos Aires: Ediciones INTA, pp. 11-15. 
DÍAZ LARRAÑAGA, N. comp. (2009) Redes para el Cambio Social. Debates Comunicacionales Interuniversitarios. $1^{\text {a }}$ ed. Bernal: Universidad Nacional de Quilmes.

DIRECCIÓN DE ESTADÍSTICA DE LA PROVINCIA DE TUCUMÁN. (2011) Censo Provincial Cañero 2011. Tucumán: Autor.

ESTACIÓN EXPERIMENTAL AGROINDUSTRIAL OBISPO COLOMBRES. (2009) Informe Análisis del proceso de acondicionado en campo y transporte de residuos agrícolas de cosecha (RAC) en verde de la caña de azúcar para su posterior combustión en calderas. Tucumán: Autor.

FERNÁNDEZ DE ULLIVARRI, E. Y PÉREZ GÓMEZ, S. (2008) EI INTA propone alternativas para evitar la quema de la caña de azúcar. Boletín de Novedades de la EEA Famaillá, 28 de octubre, p. 2.

FERNÁNDEZ DE ULLIVARRI, E. VALLEJO, J. Y VALEIRO, A. (2011) Briquetas de carbón elaboradas con residuos agrícolas de cosecha de caña de azúcar. Revista Ciencia y Tecnología de los Cultivos Industriales. Caña de azúcar, 1 (1), pp. 71-72.

FOERSTER, H. V. (1984) Observing Systems. Seaside: Intersystem Publications. En S. Massoni (2007).

FOGLIATA, F. (1995) Agronomía de la Caña de Azúcar. Vol. 1. Tucumán: Ediciones El Graduado.

FOUCAULT, M. (1969) La arqueología del saber. México DF: Siglo XXI. En S. Murillo

GALINDEZ, E. (2009) El incendio pasó, pero en Los Ralos siguen viviendo un infierno. La Gaceta (Internet) 31 de agosto. Disponible en:

$<$ http://www.lagaceta.com.ar/nota/341861/Informacion-General/El-incendio-pasopero-en-Los-Ralos-siguen-viviendo-un-infierno.html> (Acceso el 5 de noviembre de 2012)

GERACE, F. (2008) Participación y comunicación. En A. Gumucio Dragón y T. Tufte comps. Antología de la Comunicación para el Cambio Social. La Paz: Plural Editores, pp. 127-137.

GUATEMALA, MINISTERIO DE AGRICULTURA, GANADERÍA Y ALIMENTACIÓN. (2005) Manual del fuego y evaluación de daños. Petén: Editor. En P. Benedetti, y A. Valeiro, A. (2011)

GUBER, R. (2001) La etnografía. Método, campo y reflexividad. Bogotá: Grupo Editorial Norma.

GUMUCIO DRAGÓN, A. Y TUFTE, T. comps. (2008) Antología de la Comunicación para el Cambio Social. Vol. 1. La Paz: Plural Editores.

GUMUCIO DRAGÓN, A. (2009) ¿Hay democracia en Internet?. Página 12, 29 de abril, p. 26.

GUTIÉRREZ PÉREZ, F. (2008) La comunicación y la educación. En A. Gumucio Dragón y T. Tufte comps. Antología de la Comunicación para el Cambio Social. La Paz: Plural Editores, pp. 112-126. 
INSTITUTO NACIONAL DE ESTADÍSTICAS Y CENSOS DE LA REPÚBLICA ARGENTINA. (2011) Censo Nacional de Población, Hogares y Viviendas 2010. Buenos Aires: Autor.

INSTITUTO NACIONAL DE TECNOLOGÍA AGROPECUARIA. (2008) Plan Tecnológico Regional 2009-2011. Centro Regional Tucumán-Santiago del Estero. Tucumán.

2005 - 2015. Buenos Aires: Ediciones INTA. (2004) Plan Estratégico Institucional

KAPLÚN, M. (1978) Producción de programas de radio. El guión - realización. Colección Intiyan. Quito: Ediciones CIESPAL.

MASSONI, S. (2007) Estrategias. Los desafíos de la comunicación en un mundo fluido. Rosario: Ediciones Homo Sapiens.

MATA, M. C. (1994) Nociones para pensar la comunicación y la cultura masiva. Buenos Aires: La Crujía.

MOJICA, F. (2005) La construcción del futuro. Concepto y modelo de prospectiva estratégica, territorial y tecnológica. Bogotá: Convenio Andrés Bello - Univ. Externado de Colombia.

MORANDI, J. Y BUSTOS, J. (2011). Indicadores de desarrollo territorial. El caso de la caña de azúcar. Ponencia presentada a las $V$ Jornadas Nacionales de Investigadores de las Economías Regionales. La Pampa. 14-16 septiembre 2011.

MORANDI, J. RÍOS, L. Y PÉREZ, G. (2012 a) Análisis productivo y Económico del cultivo de la caña de azúcar. En R. Bongiovanni, J. Morandi y L. Troilo eds. Competitividad y calidad de los cultivos industriales: algodón, caña de azúcar, mandioca, maní, tabaco, té y yerba mate. Córdoba: Ediciones INTA, pp. 11-19. (2012 b) Dinámicas y articulaciones en la producción de azúcar, bajo el enfoque de cadena. En R. Bongiovanni, J. Morandi y L. Troilo eds. Competitividad y calidad de los cultivos industriales: algodón, caña de azúcar, mandioca, maní, tabaco, té y yerba mate. Córdoba: Ediciones INTA pp. 2033.

MORíN, D. M. (1971) El esfuerzo que el obrero realiza en la cosecha manual de la caña de azúcar. Rev. Ind. y Agrícola de Tucumán, 48 (2), pp. 59-65. En F. Fogliata (1995).

MORíN, E. (1981) El Método. La naturaleza de la naturaleza. Vol. 1. Madrid: Editorial Cátedra.

PASCUALI, A. (2008) Teoría de la Comunicación: las implicaciones sociológicas entre información y cultura de masas - Definiciones. En A. Gumucio Dragón y T. Tufte comps. Antología de la Comunicación para el Cambio Social. La Paz: Plural Editores, pp. 60-81.

PÉREZ SERRANO, G. (1993) Elaboración de proyectos sociales. Casos prácticos. Madrid: Narcea S.A. de Ediciones. En W. Uranga (2001). 
PIÑUEL RAIGADA, J. (1997) Teoría de la comunicación y gestión de las organizaciones. Madrid: Editorial Síntesis.

PRIETO CASTILLO, D. (1990) Diagnóstico de la Comunicación. Quito: Editorial Quipus.

(2000) En torno al sentido de la totalidad diagnóstico-

planificación-gestión. Mendoza: Mimeo. En W. Uranga (2001).

Crujía.

(2004) La comunicación en la educación. $2^{\circ}$ ed. Buenos Aires: La

RUÍZ REYES, M. Y ARROYO PORRAS, O. (2007) Estudio de la Contribución de Partículas Suspendidas por la Quema de Caña en la Calidad del Aire. Revista Enlace Químico, 1 (8) agosto, pp. 18-24.

SAINTOUT, F. (1998) Los estudios de recepción en América Latina. La Plata: Ediciones de Periodismo y Comunicación.

SAMAJA, J. (2003) Semiótica de la ciencia (Manuscrito no publicado). Buenos Aires. (2004) El lado oscuro de la razón. Buenos Aires: JVE Ediciones. (2006) Epistemología y metodología. Elementos para una teoría de la investigación científica. Buenos Aires: Editorial Universidad de Buenos Aires.

SCHMUCLER, H. (1997) Memoria de la comunicación. Buenos Aires: Editorial Biblos.

SCHNITMAN, D.F. ed. (1998) Nuevos paradigmas, cultura y subjetividad. Buenos Aires: Editorial Paidós.

SOPENA, R. BENEDETTI, P. Y RÍOS, L. (2011) El área cultivada con caña aumentó un $14 \%$ en la campaña 2010/2011. Indicadores de Evolución de la Provincia de Tucumán, 1 (4) octubre, pp. 26-31.

TORO, J. B. Y RODRÍGUEZ, M. (2001) La comunicación y la movilización social en la construcción de bienes públicos. Bogotá: Banco Interamericano de Desarrollo (BID).

URANGA, W. (2001) Documento Curricular y Plan de Estudios. Maestría en Planificación y Gestión de Procesos Comunicacionales. FPyCS-UNLP. La Plata: Investigaciones de la PLANGESCO.

---------. (2008) Prospectiva Estratégica desde la Comunicación. Una propuesta de proceso metodológico de diagnóstico dinámico y planificación. Buenos Aires.

VARELA, F. (1996) Conocer: las ciencias cognitivas tendencias y perspectivas. Cartografía de las ideas actuales. Barcelona: Editorial Gedisa.

VERÓN, E. Y SIGAL, S. (1986) Perón o muerte, los fundamentos discursivos del fenómeno peronista. Buenos Aires: Legasa. 
VERÓN, E. (1998) La semiosis social. Fragmento de una teoría de la discursividad. Colección El mamífero parlante. Argentina: Editorial Gedisa.

VILLAMAYOR, C. (2002) Del Módulo Gestión de la Comunicación. Tecnicatura en Comunicación. FPyCS-UNLP. La Plata: Centro de Comunicación La Crujía. (2006). La dimensión político cultural en la sostenibilidad de las radios comunitarias. Ponencia presentada al Coloquio Internacional sobre Educación Radiofónica y Medios Comunitarios: Participación, Sostenibilidad e Identidad. República Dominicana. 27-29 noviembre 2006.

(2008) La Subjetividad Oxidada. Ponencia presentada al IX Congreso Latinoamericano de Investigación de la Comunicación. México. 9-11 octubre 2008.

\section{Sitios Web consultados}

Gobierno de Tucumán http://ww.tucuman.gob.ar (consulta 21 y 22 de agosto de 2012)

Dirección de Estadística de Tucumán http://estadistica.tucuman.gov.ar (consulta 22 de agosto de 2012)

Centro Azucarero Argentino http://www.centroazucarero.com.ar (Consulta 5 de septiembre de 2012) 
Mesa de Gestión Ambiental de Cruz Alta

INTA

La firma de este Compromiso es una iniciativa conjunta de la Mesa de Gestión Ambiental de Cruz Alta (productores cañeros; Defensa Civil de Tucumán; SIPROSA; INTA; etc.) y la Secretaría de Ambiente de la Provincia de Tucumán

Los productores, empresas e instituciones participantes acuerdan apoyar la ejecución del Protocolo de Directrices Generales para Realizar Quema Controlada de Cañaverales Provenientes de Cosecha Manual y/o Semi-Mecanizada en el Departamento Cruz Alta, mediante el compromiso voluntario de observar los principios y acciones indicados en la Declaración.
La Mesa de Gestión Ambiental de Cruz Alta (productores cañeros; Defensa Civil de Tucumán; SIPROSA; INTA; etc.) y la Secretaría de Ambiente de la Provincia de Tucumán convienen en promover ampliamente la participación de los

\section{COMPROMISO DE ADHESIÓN VOLUNTARIA AL PROGRAMA PILOTO DE ERRADICACIÓN DE LA QUEMA DE CAÑA DE AZÚCAR EN EL DEPARTAMENTO CRUZ ALTA, TUCUMÁN}

ZAFRA 2011

Adhesiones en: Pasaje Alberdi 202 - Banda del Río Salí (8.30 a 14.30 hs)

A través de la firma del presente Compromiso Voluntario el/la

Señor/a

afirma que su finca se ubica en el Departamento Cruz Alta,

identificándose con los siguientes datos del Registro de Productores

Cañeros de la Secretaría de la Producción de

Tucumán:

y declara que

entiende estar comprendido/a en los términos del Decreto 795 / 2005

(Modificado por Decreto no 2523/9-2008) y solicita una excepción para

realizar la quema controlada de.

hectáreas de caña de

azúcar a cosechar en forma manual y/o semi-mecanizada.

Al mismo tiempo, se compromete a implementar una reducción progresiva de la quema de caña en su finca, que termine en la eliminación total del uso de esta práctica como máximo en 2024. En futuras solicitudes, deberá acreditar el cumplimiento de las metas de reducción del año anterior, e indicar las metas de reducción para el año en curso, y la porción del fundo en que se aplicará la quema.

El firmante declara saber que está prohibida, sin excepción, la quema de caña de azúcar en pié y en los siguientes casos:

a) En un radio de 1 (un) Kilómetro desde los bordes urbanos;

b) En la zona de dominio de los cables de alta tensión y redes troncales de gas que comprende una franja de 12 metros a cada lado de la línea de conducción;

c) En un radio de 500 (quinientos) metros alrededor de las subestaciones de energía eléctrica de concesionarias;

d) En un radio de 1 (un) kilómetro desde el borde perimetral de los aeropuertos y aeródromos.

e) En un área dentro de 100 (cien) metros a cada lado de la franja de dominio de rutas nacionales o provinciales, y de red ferroviaria;

f) En un radio de 500 (quinientos) metros alrededor de las áreas protegidas;

Como contraparte a la excepción solicitada, el/la firmante se compromete a seguir las siguientes directrices:

1. Solicitar autorización a Defensa Civil llamando al $\mathbf{1 0 3}$ (número gratuito desde cualquier teléfono), invocando el número de registro correspondiente, e informando la superficie a quemar dentro de los límites de la ley.

2. Defensa Civil solicitará información meteorológica y 
productores, empresas e instituciones del sector cañero en este Programa Piloto y reportar los avances que se alcancen en ese sentido. pronóstico del tiempo a organismos a determinar, y define momento adecuado de quema controlada.

3. Defensa Civil comunicará al productor el momento adecuado (día y hora) para realizar la quema controlada dentro de los límites de la ley.

4. Defensa Civil avisará a Cuartel de Bomberos cercano, los que permanecerán en alerta.

5. El productor dará aviso a Policía, y vecinos sobre la fecha, hora y ubicación de la quema controlada dentro de los límites de la ley.

6. El productor realizará la quema, preferentemente, después de las 18:00 hs y hasta las 05:00 hs del día siguiente, para trabajar con temperaturas más bajas, mayor contenido de humedad en el aire y disminuir las cantidades humo en las áreas pobladas. Como regla general nunca se iniciará una quema controlada cuando se den una o más de las siguientes condiciones:

a) La humedad relativa (HR) del aire sea menor a $35 \%$;

b) La Temperatura ( $\mathrm{T}$ ) ambiente sea mayor a $30^{\circ} \mathrm{C}$;

c) La Velocidad del Viento (VV) sea superior a $30 \mathrm{Km} / \mathrm{h}$; y

d) Exista la posibilidad de un cambio en la dirección del viento en menos de 12 hs.

7. Si el lugar de quema se encuentra próximo a rutas y caminos muy transitados (aún a distancias mayores a $100 \mathrm{~m}$. de acuerdo a la ley), el productor tomará los recaudos necesarios para señalizar adecuadamente la presencia de humo, de acuerdo a la legislación vigente (Ley 24449, de Tránsito).

8. La quema siempre deberá iniciarse en sentido opuesto a la dirección general del viento; o sea, se debe usar la técnica de ignición de fuego en retroceso; con el fin de garantizar un comportamiento más calmo del fuego y mayor seguridad en el manejo del mismo.

9. El productor deberá mantener personal durante todo el proceso de quema debidamente equipado para el control de posibles escapes de fuego.

10. El productor deberá asegurar la presencia de personal desde el inicio de la quema controlada hasta que se encuentre asegurada su extinción.

11. Una vez extinguido el fuego, el productor avisará a Defensa Civil (103) que la situación de peligro potencial ha pasado.

Esta excepción sólo tiene vigencia para la presente zafra, siendo necesario repetir el proceso todos los años.
FIRMA Y ACLARACIÓN

Banda del Río Salí,... 


\section{Mesa de Gestión Ambiental de Cruz Alta}

\section{INTI \\ Directrices Generales para Aviso de Incendios de Vegetación: \\ Estos serían los pasos a seguir en caso de incendios accidentales o generados intencionalmente por acción de terceros}

más próximo.

1. Inmediato aviso al cuartel de bomberos más cercano y/o al puesto policial

2. $\quad$ Aviso a la Dirección de Defensa Civil (DC), a través del teléfono 103.

3. DC queda en alerta y avisa situación a cuarteles de bomberos de la zona para que queden en alerta.

4. $\quad$ El productor deberá asegurar la presencia de personal y equipos desde el inicio del incendio, como colaboración y a las órdenes de Bomberos y/o DC hasta que se encuentre asegurada su extinción.

5. Si el fuego es controlado y extinguido, el cuerpo de bomberos responsable avisa de esta situación a DC.

6. DC comunica de la novedad a los otros cuerpos de bomberos que estaban en alerta.

7. Si el accidente de fuego supera la capacidad operativa de los bomberos locales, éstos avisan de la situación a DC.

8. DC dispone y coordina el accionar de otros cuerpos de bomberos en apoyo a la situación.

9. DC define el momento cuando el siniestro está controlado y extinguido.

Paralelamente a la aplicación de estas directrices, se difundirán ampliamente otras acciones para prevención de incendios:

Normas de precaución y resguardo para evitar la quema de los residuos provenientes de la cosecha integral de caña de azúcar.

1. Realizar la limpieza de callejones laterales y cabeceras de cultivo, con labores de rastreo, cuando las condiciones del suelo apenas lo permitan, especialmente desde fines de mayo. En lotes aledaños a banquinas de rutas y caminos vecinales, extremar estas medidas de prevención.

2. Coordinar con fincas vecinas y aledañas al predio y personal de mantenimiento de reparticiones gubernamentales, la limpieza de las banquinas y servidumbres.

3. Dentro del predio, una vez cosechado, extremar las medidas de control para evitar la quema del residuo vegetal, a partir de ciertas medidas tales como:

a. Control de grama incipiente, con tareas de repaso de cabeceras una vez finalizada la cosecha, labor que también se implementa para nivelar el terreno.

b. Conformar brechas y melgas cortafuegos, en tablones ya cosechados. Con equipo de cultivo de discos, triturar e incorporar la maloja en al menos 3 surcos contiguos, con la posibilidad de un mínimo aporque para disminuir al máximo la posibilidad de maloja en superficie. Se sugiere delimitar estas melgas cada 20 a 30 surcos y que los tablones 0 subunidades de estos no superen las 20 has, sin cortafuegos mediante. 


\section{ANEXO 2}

Afiche sociedad "Quemar nos hace mal a todos"

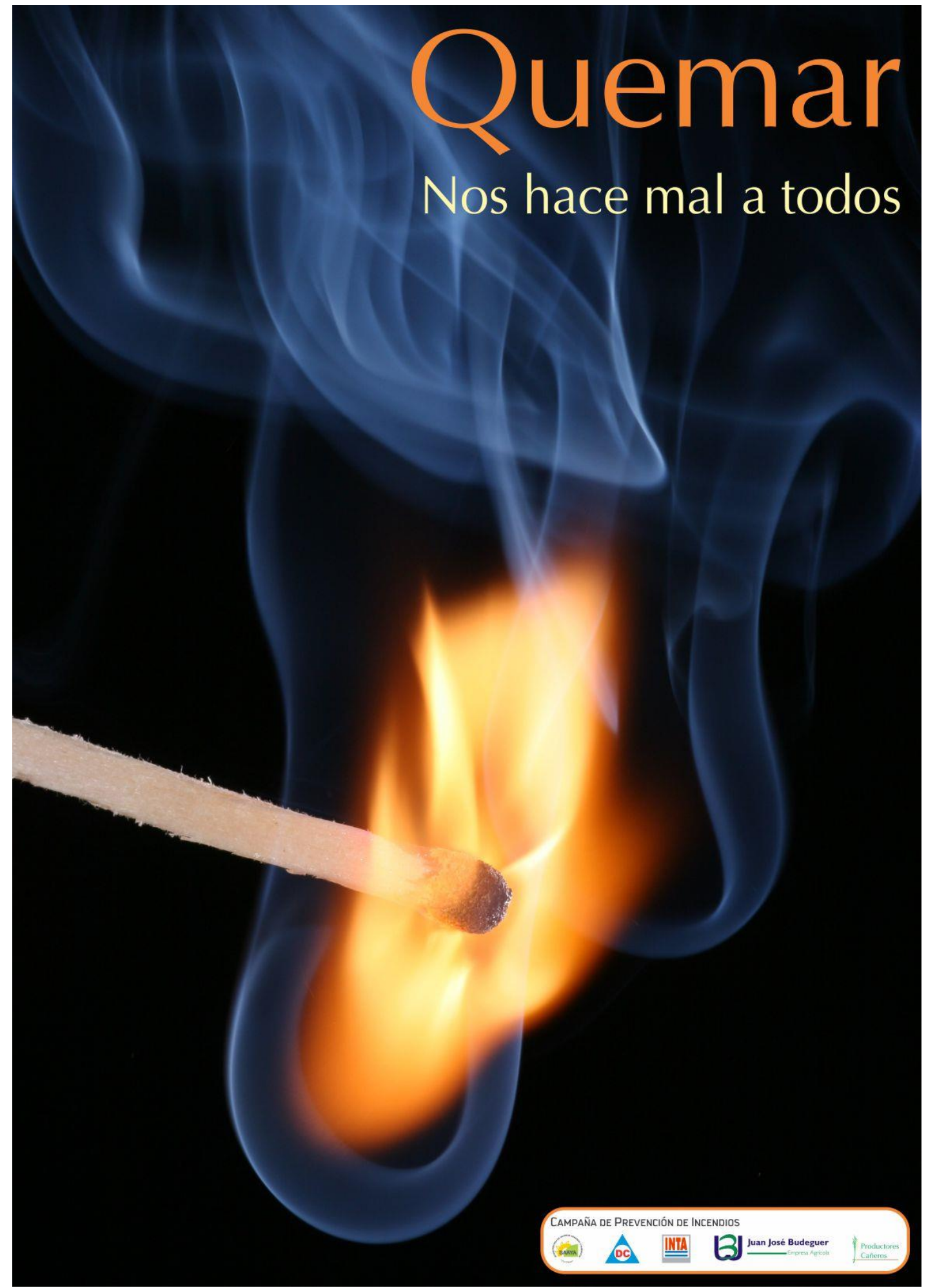


Afiche sociedad "Prender fuego no es un juego"
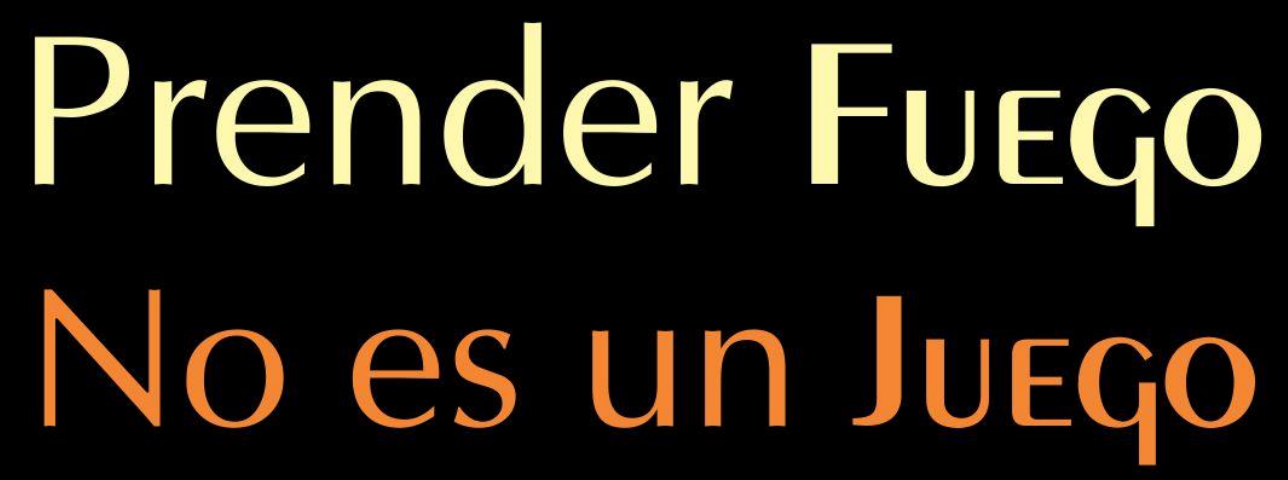
Afiche productores "Quemar caña nos afecta a todos"

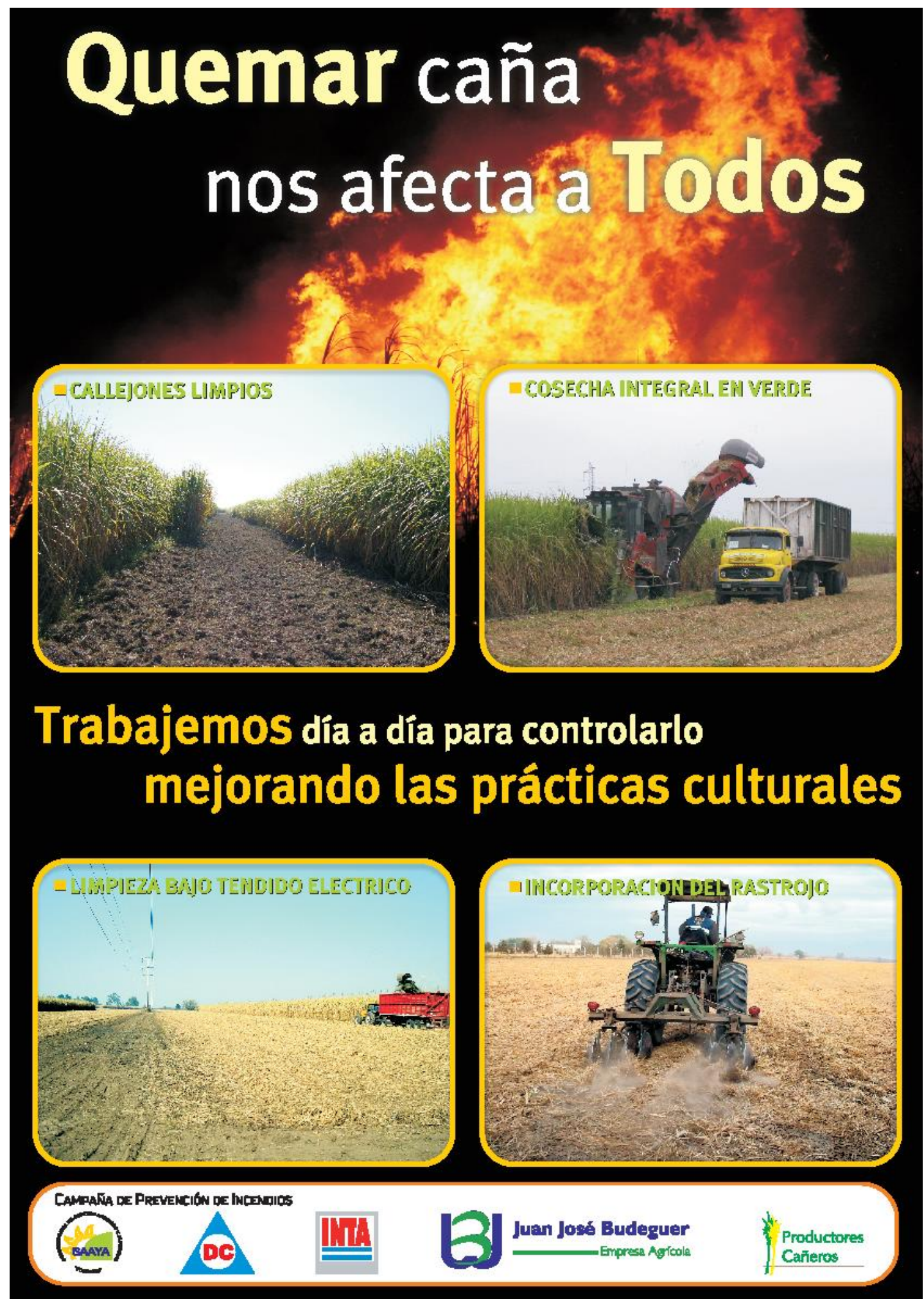




\section{ANEXO 3}

Spot televisivo y radial "Entre todos podemos cuidar nuestra provincia"

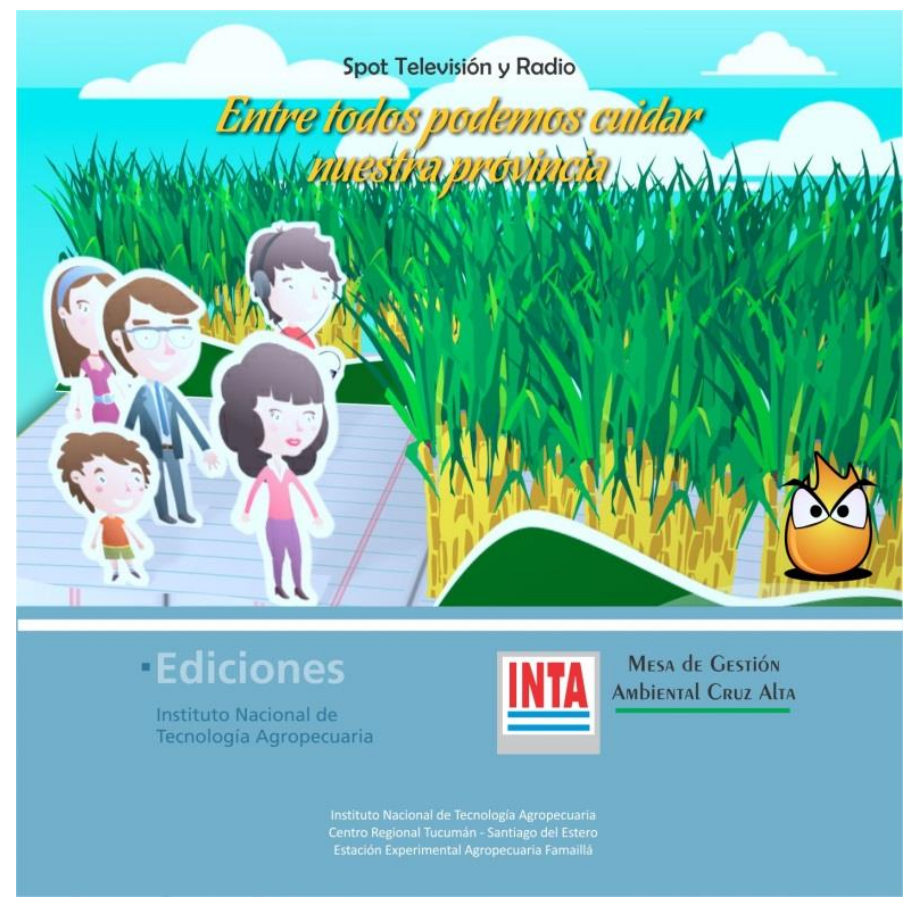


ANEXO 4

Folleto "Entre todos podemos cuidar nuestra provincia"
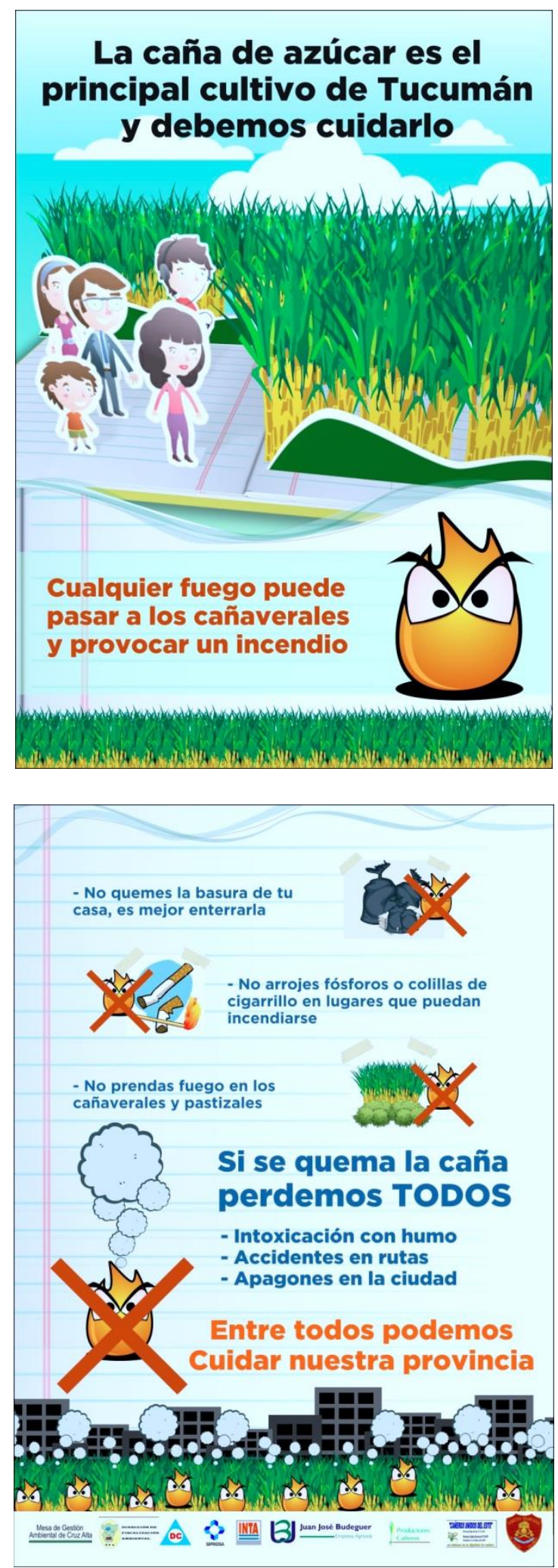


\section{ANEXO 5}

Video "Prender fuego no es un juego"
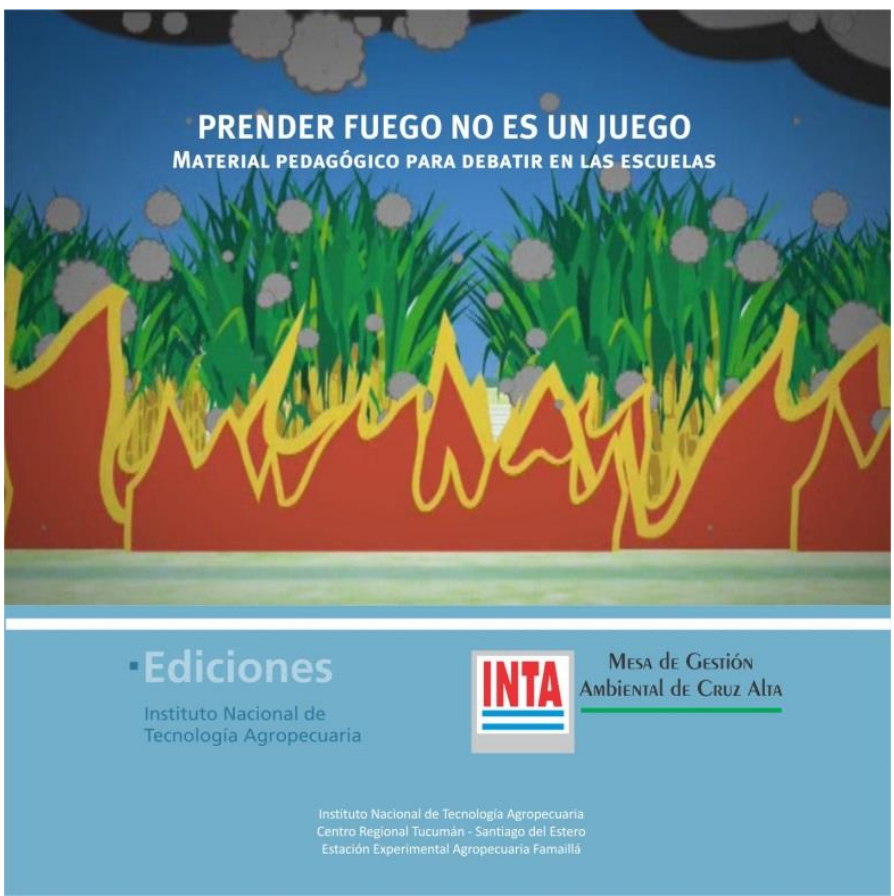


\section{ANEXO 6}

\section{Folleto "Erradiquemos la quema de caña de azúcar"}
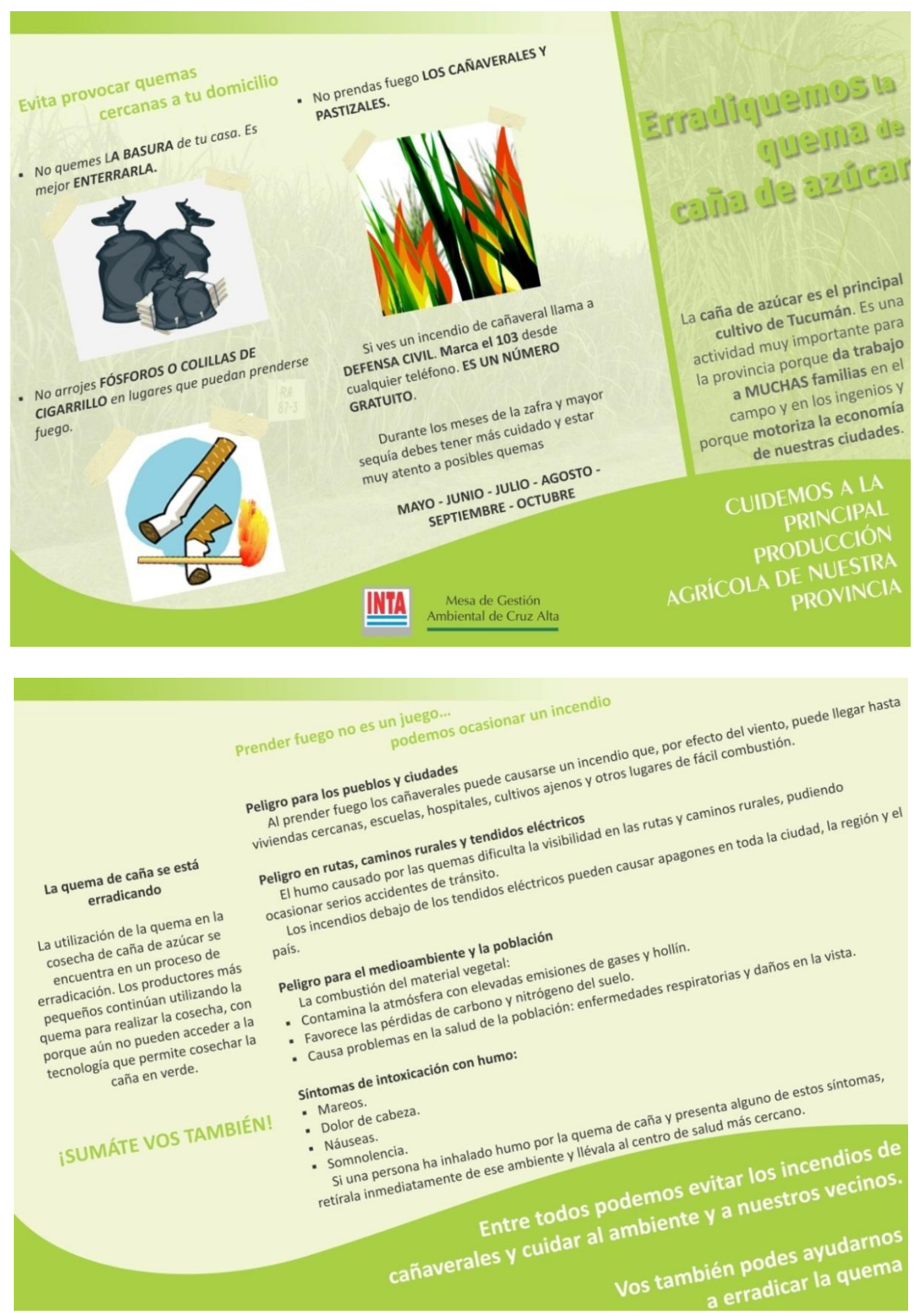
Notas publicadas por el diario La Gaceta - 25/07 al 06/08/2012

\section{LA GACETA}

Miércoles 08 de Mayo de 2013 | 11:18 | 5,387 lectores conectados

$17^{\circ} \mathrm{C}$

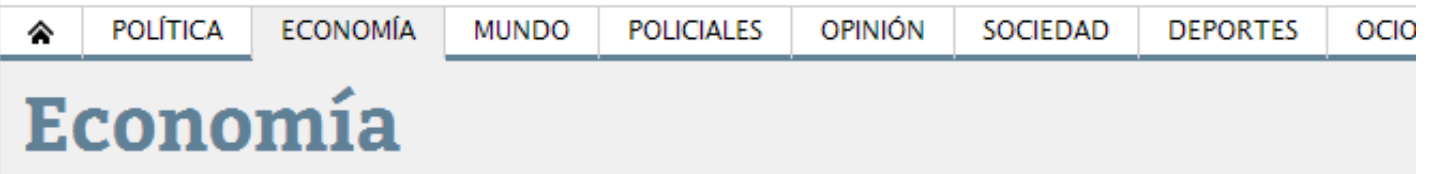

" CONTAMINACION | ZAFRA 2012

\section{El INTA propone que quemen caña sólo pequeños productores}

El organismo informó que también se detectan incendios en otros tipos de cultivos. La entidad agropecuaria cree que es conveniente reformar la ley que regula la quema de cultivos, para mejorar controles.

Miércoles 25 de Julio de 2012

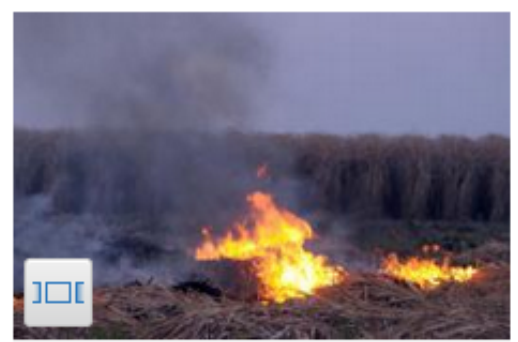

EN CAMPOS. Según los registros de Defensa Civil provincial, aumentaron las denuncias por incendios. LA CACETA / FOTO DE ENRIQUE CALINDEZ (ARCHIVO)
La mayoría $\mathrm{A}^{+} \mathrm{A}^{-}$ म de las organizaciones ambientalistas considera que los productores can̂eros son responsables directos de los persistentes dafíos ambientales, debido a la quema de cultivos. Pero también se los identifica como eventuales actores en un problema de fondo: la contaminación. Esas observaciones surgen al plantearse una especie de vacío legal de la Ley provincial $\mathrm{N}^{\circ} 7459$. En medio de la creciente aparición de focos de incendios en campos, el Instituto Nacional de Tecnología Agropecuaria (INTAFamaillá) requiere una revisión de la actual norma al dofinirla do difíril anliraríńn on la nrouinria

Disponible en: http://www.lagaceta.com.ar/nota/502381/economia/inta-proponequemen-cana-solo-pequenos-productores.html 


\section{LA GACETA}

Miércoles 08 de Mayo de 2013 | 11:35 | 5,400 lectores conectados

Economía

" RELEVAMIENTO | FUEGO EN LOS CAMPOS

\section{El 55\% de la quema se detecta en basurales, montes y rutas}

Afirman que un alto porcentaje de incendios está fuera de las manos de los productores. En Tucumán hay nueve áreas "calientes y de conflicto", según el informe de la Mesa de Gestión Ambiental para Cruz Alta

Jueves 26 de Julio de 2012

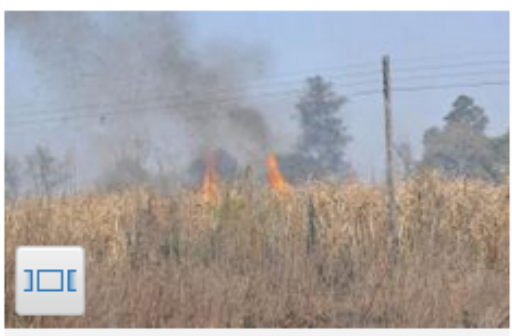

MONITOREO. Según el seguimiento satelital, los incendios se detectan cada vez más cerca de las poblaciones. LA CACETA / FOTO DE OSVALDO RIPOLL
मे

En el territorio provincial están identificadas $\quad \mathrm{A}^{+} \mathrm{A}^{-}$ nueve "áreas calientes" y cada una se extiende en 10 hectáreas. Esas zonas se encuentran en los departamentos Cruz Alta, Leales, Famaillá, Monteros y Simoca, y en ellas se llegan a visualizar un promedio de 52 focos de incendio por afo. Sin embargo, el dato más significativo es que de las masas de fuego senaladas, sólo el $45 \%$ corresponde a quema de cafla de azúcar; el resto obedece a incendios originados en basurales, montes y en rutas, utilizados como "herramienta de limpieza o higiene".

Feac identifirarinnoc rolousdac nnr al lahnraterin dal

Disponible en: http://www.lagaceta.com.ar/nota/502586/economia/55porcientoquema-se-detecta-basurales-montes-rutas.html 


\begin{tabular}{l|l|l|l|l|l|l|l|l|} 
^ & POLITICA & ECONOMIA & MUNDO & POLICIALES & OPINIÓN & SOCIEDAD & DEPORTES & OCIO \\
\hline & & &
\end{tabular}

\title{
El plan de erradicación progresiva de incendios tiene dos años
}

\author{
El Laboratorio de Sistema de Información Territorial de la Estación \\ Experimental Agropecuaria Famaillá del INTA detectó áreas calientes
}

Viernes 27 de Julio de 2012

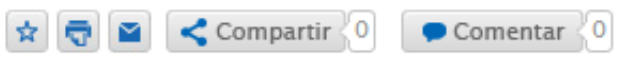

En la zona de Cruz Alta se desarrolla un programa de erradicación progresiva de $\quad \mathbf{A}^{+} \mathbf{A}^{-}$ la quema de cafla de azúcar. El plan es impulsado por la Mesa de Gestión Ambiental para el Departamento Cruz Alta, integrada por el INTA, productores y cooperativas de producción, la Secretaría de Medio Ambiente y otras reparticiones gubernamentales.

Se trata de una experiencia que viene concretándose desde 2010 y que está dirigida de manera integral no sólo a los caf̂eros de la zona, sino también a la sociedad. El programa impulsa un lineamiento para la quema controlada, proveniente de cosecha manual y semimecanizada. Esta idea forma parte del plan que apunta a la reducción de los incendios en caf̂averales, y sustenta a su vez el planteo de la revisión de la Ley actual con el fin de establecer una marco legal claro, según había afirmado el asesor productivo Manuel Ponce. El programa de prueba también incluye actividades educativas en escuelas de la región. "Es un problema bastante complejo y la responsabilidad no sólo es del sector productivo, sino de

Disponible en: http://www.lagaceta.com.ar/nota/502763/economia/plan-erradicacionprogresiva-incendios-tiene-dos-anos.html 


\section{LA GACETA}

Miércoles 08 de Mayo de 2013 | 11:43 | 5,389 lectores conectados

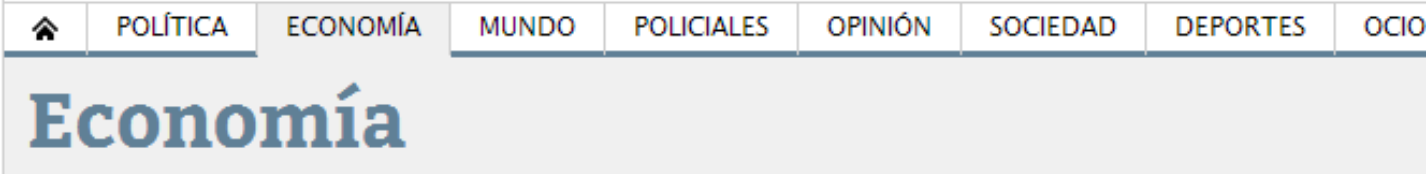

" CONTAMINACIÓN | FOCOS DE INCENDIOS

\section{La quema vigilada de caña genera rechazos}

La propuesta de la Mesa de Gestión Ambiental para Cruz Alta no es aceptada por políticos opositores, ambientalistas ni profesionales. En la Cámara se abrirá hoy el debate para una posible revisión de la norma vigente. Reuniones con el sector cañero

Viernes 27 de Julio de 2012

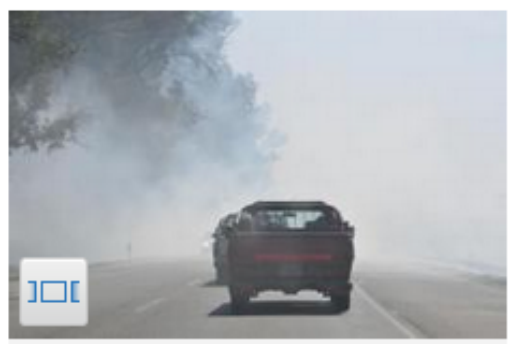

HUMO CAMINERO. Los incendios dificultan la visibilidad en las rutas, perjudican la salud de la población y

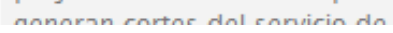

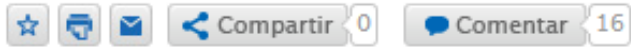

Los grupos ambientalistas y sectores de la oposición salieron a cuestionar la actual política ambiental del Gobierno provincial. Además, rechazaron la iniciativa de permitir a los pequefios cafleros emplear la quema de cafla vigilada, propuesta por los integrantes de la Mesa de Gestión Ambiental para el Departamento de Cruz Alta, enmarcada en una plan de erradicación de esta práctica en cañaverales.

Movimiento Popular Tres Banderas (MP3), que integra el Frente Amplio Progresista (FAP), dirigió su crítica al

Disponible en: http://www.lagaceta.com.ar/nota/502762/economia/quema-vigiladacana-genera-rechazos.html 


\section{LA GACETA}

Miércoles 08 de Mayo de 2013 | 11:46 | 5,432 lectores conectados

\begin{tabular}{|c|c|c|c|c|c|c|c|c|}
\hline 今 & POLÍTICA & ECONOMIA & MUNDO & POLICIALES & OPINIÓN & SOCIEDAD & DEPORTES & $\mathrm{OCIC}$ \\
\hline
\end{tabular}

" CONTAMINACIóN | INCENDIOS EN CAñAVERALES

\section{Avanza la revisión de la norma provincial}

La Legislatura analiza la incorporación de la quema controlada y la erradicación progresiva

Sábado 28 de Julio de 2012

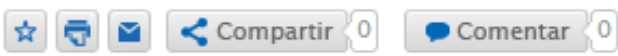

En la Legislatura se analiza ya una revisión del marco legal actual de la quema de $\quad \mathrm{A}^{+} \mathrm{A}^{-}$ caña. Ayer, en una mesa de evaluación encabezada por los legisladores de la Comisión de Medio Ambiente, se puso en relieve como alternativa la incorporación a la Ley Provincial de Medio Ambiente $\left(\mathrm{N}^{\circ} 6.253\right)$ de un protocolo de adhesión para minifundistas, que apunta a la erradicación progresiva de los incendios en cafhaverales.

Los legisladores se reunieron con el secretario de Medio Ambiente, Alfredo Montalván, el Defensor del Pueblo, Hugo Cabral, y con la directora regional reemplazante del INTA Tucumán-Santiago del Estero, Daniela Bustos, entre otros técnicos del instituto nacional agropecuario. En el encuentro se planteó la posibilidad de adaptar el programa piloto impulsado por la Mesa de Gestión Ambiental para el Departamento Cruz Alta, en particular, una guía de acción para los can̂eros que contempla la quema controlada y la reducción progresiva de los incendios.

Disponible en: http://www.lagaceta.com.ar/nota/502919/economia/avanza-revisionnorma-provincial.html 


\section{LA GACETA}

$21^{\circ} \mathrm{C}$

Miércoles 08 de Mayo de 2013 | 11:49 | 5,380 lectores conectados

Apinión

wEBTronat

\section{La práctica de la quema del cañaveral}

Lunes 06 de Agosto de 2012

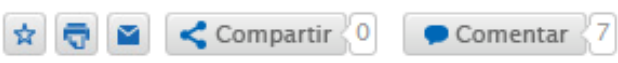

Cada vez más alarmante y, progresivamente, intolerable, se ha convertido ya la $\quad A^{+} \mathbf{A}^{-}$ quema de caña y de pastizales en el territorio provincial. El fuego y el humo con sus efectos contaminantes que genera esta práctica, especialmente en la temporada de zafra, se ha convertido en un problema grave, serio y profundo que pone en riesgo vidas y bienes personales.

Casi a diario, en estas últimas semanas, se ha informado de incendios en diversas fincas y lugares que deben ser combatidos por los bomberos, campesinos o socorristas circunstanciales, la mayoría de las veces a puro fervor y voluntad. Ese fuego por poco generó más de una tragedia en Bella Vista y Aguilares, cuando se expandió sin control, a tal punto que estuvo próximo a rodear esas ciudades y otros poblados del sur tucumano.

Asumido inicialmente como una antigua práctica de los productores cafieros para bajar los costos de la cosecha, la quema de las hojas y los rastrojos de la cafla se han transformado en un drama para miles de tucumanos, toda vez que esos episodios producen efectos nocivos para la salud, contamina severamente el medio ambiente, provoca accidentes en las rutas, daf́a las líneas de alta tensión eléctrica y genera perjuicio al sistema de navegación aérea.

Disponible en: http://www.lagaceta.com.ar/nota/504356/opinion/practica-quemacanaveral.html 